\title{
DOES FINANCIAL SUPPORT FROM THE ERDF AND CF CONTRIBUTE TO CONVERGENCE IN THE EU? EMPIRICAL EVIDENCE AT NUTS 3 LEVEL*
}

\author{
Mindaugas Butkus ${ }^{a}$, Alma Mačiulytè-Šniukienè ${ }^{a}$, Kristina \\ Matuzevičiutè ${ }^{a}$ Diana Cibulskienè ${ }^{a}$
}

\begin{abstract}
Analysing papers that reveal by decomposing territorial inequalities in the EU that the share of disparities attributed to the NUTS 3 level has increased over the last 20 years, this paper aims to examine to what extent the financial support in 2000-2006 from ERDF and CF, which are the main regional policy tools but mainly are directed to address the issues arising at the NUTS 2 level, contributed to supporting convergence at the NUTS 3 level. Our research strategy relies on combining a conditional $\beta$-convergence model and a differencein-differences (DiD) estimator. Estimations are generated for four alternative post-policy periods, two ways to measure policy intervention and for different funds as well as different expenditure categories. Our research results bring to light the question of potential negative outcomes of the EU's existing regional policy since the policy that is focused on the NUTS 2 level is enlarging imbalances within these regions, i.e., among NUTS 3 regions.
\end{abstract}

Keywords: European Regional Development Fund (ERDF), Cohesion Fund (CF), regional disparities, convergence, NUTS 3, financial support

JEL Classification: O47, F15, R12, R58

\section{Introduction}

Cohesion policy (CP) is the main instrument used in the EU to support harmonious growth in member states (MS). Over different programming periods, the amount and direction of the investment reflect the EU's goals, and the effectiveness of the CP can be measured

a Šiauliai University, Lithuania

Email: mindaugas.butkus@su.lt, alma.maciulyte-sniukiene@su.lt,diana.cibulskiene@su.lt, kristina.matuzeviciute@su.lt

* This work is a part of the researchers' group project on the Assessment Model of Return on the EU Regional Support (AMREUS) that has received funding from the Research Council of Lithuania under agreement no. S-MIP-17-114.

The authors would like to thank two anonymous reviewers for comments and suggestions on this paper that gave insights for future research. 
by comparing goals with achievements. The return on investment of EU Structural Funds (SF) is a broadly researched topic. The studies (Becker et al., 2010, 2012, 2013, 2018; Mohl and Hagen, 2010; Pellegrini et al., 2013; Rodriguez-Pose and Novak, 2013; Accetturo et al., 2014; Pinho et al., 2015 a,b; Rodriguez-Pose and Garcilazo, 2015; Di Cataldo, 2017; Gagliardi and Percoco, 2017, etc.) examined what impact the SF had on regional economic growth and convergence. The leading article by Becker et al. (2018) covering the last four programming periods reveals a positive but not very long-lived impact of the SF on per capita GDP and employment growth and an insignificant effect on private and public investment.

Positive SF contribution to growth is revealed by a lot of studies, but the effect depends on some conditions: absorptive capacity (Becker et al., 2013; Pinho et al., 2015a; Gagliardi and Percoco, 2017); intensity of transfers (Kyriacou and Roca-Sagalés, 2012; Pellegrini and Cerqua, 2016; Di Cataldo, 2017); expenditure category and intervention area (Pontarollo, 2017); and institutional quality (Becker, 2012; Kyriacou and RocaSagalés; Dotti, 2016). Moreover, the effect is not robust to the selected period and applied estimation methods. Also, it should be noted that previous contributions mainly focus on growth and convergence dynamics at the NUTS 1 and 2 levels, leaving the question whether SF investment contributed positively to convergence at the NUTS 3 level.

Research (Smetkowski and Wójcik, 2012; Bourdin, 2015; Hegerty, 2016; Percoco, 2017) reveals that convergence occurs at the national but not the regional level and that disparity is sharper and convergence is less clear when smaller territorial units are considered. Continuing the research by Butkus et al. (2018), which revealed by decomposing territorial inequalities in the EU up to the NUTS 3 level that disparities between smallest territorial units are growing and the share of inequalities attributed to NUTS 3 now is the highest for the last twenty years, this paper aims to examine effects of the $\mathrm{CP}$ on disparities among NUTS 3 regions.

Aiming to fill the gap of empirical research on how the EU's financial support contributes to regional convergence at the NUTS 3 level, the research integrates a conditional $\beta$-convergence model and a DiD estimator. Our empirical analysis is based on EU-25 NUTS 3 data and estimations generated for ERDF and CF allocations combined as well as for separate fund and expenditure categories using dummy variables for eligibility and alternatively funding intensity. The effect of support over the 20002006 programming period is estimated on regional convergence over 5-8 year periods each of which starts in 2007. For the robustness check, we alternatively estimated our model for two alternative post-policy periods as well as for reduced sample size.

The paper is organized as follows: Section 2 presents a literature review on SF impact on regional growth and convergence, Section 3 describes the methodology and 
estimation strategy, the next section provides estimation results and discussion, and the last section concludes the paper.

\section{Literature Review}

Three theoretical approaches are commonly used to analyse the impact of SF on growth and convergence. The traditional approach is based on Solow (1956) and Swan's (1956) neoclassical growth theory further developed by Barro and Sala-i-Martin (1991, 1992) with assumptions of diminishing marginal returns and exogenous technological progress. According to Pinho et al. (2015a), if SF are transferred to capital-scarce regions, less developed economies should experience faster economic growth in the short run compared to more developed ones and, in the long run, the growth rates should become similar due to decreasing return on capital investments. According to this approach, exogenously determined technological development increases the steady-state regional growth rate. The most relevant study adapting neoclassical theory to estimate SF impact on growth is by Pinho et al. (2015b). Applying a conditional $\beta$-convergence model, the research evaluated SF impact on EU-12 NUTS 1 and 2 regions over the period 1995-2009 and came to the general conclusion that the SF had a positive impact on real income growth only in richer, highly educated and more innovative regions.

The second strand of the research is based on the endogenous growth theory, assuming constant returns to capital, endogenous technological progress, and local externalities. Theory argues that economic growth is primarily the result of endogenous rather than exogenous factors. It assumes that public investments stimulate private capital expenditure (Romer, 1990). As Romer (1990, 1994) emphasizes, investing in human capital, innovation and knowledge are important growth factors. Theory focuses on the positive externalities and the dissemination of knowledge in a knowledge-based economy and states that economic growth and the impact of endogenous factors on growth depend on the institutional environment. Only a few studies analysing the return on SF payments over the 2000-2006 programming period have used this growth theory and its applications differ. For example, Kutan and Yigit (2007) applied a stochastic endogenous growth model to evaluate the impact of SF and CF transfers on convergence and growth in 5 EU MS using quarterly state-level data for 1980-2004. The study revealed a positive effect on convergence in the short run and on overall growth due to capital accumulation. Varga and Veld (2010) used endogenous modelling to analyse CP effects on economic growth in EU-16 MS that receive large allocations of funds over the period 2000-2006. The study revealed a positive return of CP in less developed EU MS and that the return is higher in the medium and long run. 
The third strand of growth theory is related to the new economic geography (Fujita et al., 1999), which states that regional economic development depends on transportation costs, economies of scale and the share of manufacturing in regional income. In this framework, transport improvement and development of accessibility of interregional transportation infrastructures promote competitiveness and cohesion (Vickerman et al., 1999). We did not find any research concerning returns on SF support over the period 2000-2006 which would be based purely on the economic geographic approach. Typically, research models are not grounded in a single approach; they are more or less eclectic, integrating two or even all three approaches and thus our presented division of the research according to the theoretical approach adopted is to some extent a matter of subjectivity.

The main results of studies that combine several theoretical approaches are presented in the online Appendix A.

It should be noted that all the research has evaluated effects of SF payments at the country, NUTS 1 and 2 levels, except two studies. Fratesi and Perucca (2014) examined the impact of SF payments over 2004-2006 on GDP growth rate over 2006-2010 covering NUTS 3 regions of EU-10 MS. The study concludes that regional policy is not very effective per se, but its effectiveness depends on "territorial capital". Gagliardi and Percoco (2017) investigated SF impact on economic growth covering 1233 NUTS 3 EU-25 regions and found a positive effect on growth only in lagging regions, which usually have a lower absorption capacity. Hence, these results contradict the findings of Fratesi and Perucca (2014). Analysis of previous studies has also revealed that there is no research examining the impact of SF payments over 2000-2006 on convergence at the NUTS 3 level. Thus, our research will fill this gap.

\section{Data and Model}

Aiming to estimate the effect of the ERDF and CF on convergence among NUTS 3 regions in the EU, i.e., to examine whether SF investment has had a positive return, we combined a neoclassical conditional $\beta$-convergence approach and a DiD estimator. The most general equation (Barro, Sala-i-Martin, 1991, 1992) to estimate conditional $\beta$-convergence takes the form:

$$
\frac{1}{P-p} \ln \left(\frac{g d p_{P}}{g d p_{p}}\right)=\alpha+\beta \cdot \ln \left(g d p_{i, p}\right)+\text { other growth controls }{ }_{i}+u_{i},
$$

where $\frac{1}{P-p} \ln \left(\frac{g d p_{P}}{g d p_{p}}\right)$ is the average growth rate of regional per capita GDP from the initial period $p$ to $P, g d p_{t, p}$ is the initial per capita GDP in the region $i$, and remaining 
are the usually interpreted constitutions of a common growth equation based on crosssectional data. An estimated negative and significant $\beta$ would signal an inverse correlation between the initial per capita GDP and its growth rate over the following years, i.e., convergence.

One of the other growth controls that we would like to include in Equation 1 is ERDF and CF funding, which is primarily directed to lagging regions aiming to boost their growth. In this research, we take the approach to $\mathrm{CP}$ as to quasi or natural experiment conditions when a policy intervention affects only a part of regions leaving a naturally occurring contrast group. Non-randomness of funding eligibility leads to inhomogeneous treatment and control groups in terms of other growth controls. It would not be a problem if these factors are in a zero correlation with eligibility (which is probably not true since regional growth factors are the main conditions for funding eligibility) or we could control them in the growth Equation 1, which is also not very likely having a scarcity of proxies for growth factors at the NUTS 3 level. All that would probably lead to the fact that the error term (which accounts for unobservable growth factors) in the growth Equation 1 would be in a non-zero correlation with eligibility to treatment and thus there would be condition inconsistency of OLS estimates in the cross-sectional regression.

To address this issue, we can alternatively construct a DiD estimator taking advantage of two period data for the same cross-sections, i.e., one before the policy intervention and one after. Having the same cross-sections over both periods gives us the advantage of controlling for differences between the treatment and control groups already before the $\mathrm{CP}$ took place. Comparing the pre-policy contrast with the one observed after the policy intervention, we can estimate the effect of the latter using the DiD estimator:

$$
\delta_{1}=\left(\overline{g r_{T, t 2}}-\overline{g r_{C, t 2}}\right)-\left(\overline{g r_{T, t 1}}-\overline{g r_{C, t 1}}\right),
$$

where $g r_{T, t 2}$ is the growth rate over the post-policy period (post-pp) for the region in the treatment group ( $t g), g r_{C, t 2}$ is the growth rate over post-pp for the region in the control group ( $c g), g r_{T, t 1}$ is the growth rate over the pre-policy period (pre-pp) for the region in the $t g$, and $g r_{C, t 1}$ is the growth rate over pre-pp for the region in the $c g$. The bar above the variables indicates group average. Assignment into the $t g$ and the $c g$ over the 2000-2006 programming period (policy intervention period) is presented in the online Appendix B.

The estimator presented in Equation 2 allows us to estimate the size, but not the statistical significance of the intervention effect, and does not control for other factors that are important for growth. We can estimate the DiD and test its significance using the regression equation:

$$
g r_{i}=\beta_{0}+\delta_{0} \cdot t 2+\beta_{1} \cdot d T_{i}+\delta_{1} \cdot t 2 \cdot d T_{i}+\varepsilon_{i}
$$


where $t 2$ is a dummy that equals 1 for post-pp and equals 0 for pre-pp, $d T_{i}$ is a dummy that equals 1 if the region belongs to the $\operatorname{tg}$ and 0 otherwise. $\beta_{0}$ is the average regional growth rate in the $c g$ over pre-pp, i.e., $\overline{g r_{C, t 1}}$. $\delta_{0}$ is equal to $\overline{g r_{C, t 2}}-\overline{g r_{C, t 1}}$ and shows how the average growth rate in the $c g$ changed over post-pp compared to $p r e-p p$. $\beta_{1}$ is equal to $\overline{g r_{T, t 1}}-\overline{g r_{C, t 1}}$ and shows the difference in the average growth rates between the $t g$ and the $c g$ over pre-pp. $\beta_{1}$ is expected to be positive, because according to the convergence hypothesis, less developed regions (LDR), which are under policy consideration, experience faster growth. $\delta_{1}$ is the DiD estimator that shows how the difference in average growth rate between the $t g$ and the $c g$ changed over post-pp compared to pre-pp. A positive coefficient in $\delta_{1}$ would be evidence of successful contribution of the ERDF and $\mathrm{CF}$ to regional convergence.

To control for other factors that might explain regional variation of growth rates, we combine Equations 1 and 3:

$$
g r_{i}=\alpha+\beta \cdot \ln \left(g d p_{i, P}\right)+\delta_{0} \cdot t 2+\beta_{1} \cdot d T_{i}+\delta_{1} \cdot t 2 \cdot d T_{i}+\text { other growth controls } s_{i}+\varepsilon_{i},(4)
$$

where $g r_{i}$ is the average growth rate of regional per capita GDP, other growth controls $s_{i}$ cover: average growth rate of working age population, sectoral mix (initial share of value added (VA) in the agriculture, industry and service sectors), dummies for capital, coastal region, port dummy, urban and rural dummies (intermediate region is set as a benchmark), country dummies to account for country-specific time trends (for data sources and descriptive statistics see the online Appendix C). We would like to stress here that a shortage of data on common neoclassical growth factors at the NUTS 3 level motivates us to proxy them using regional typologies and local information, which is quite usual in growth models (see Paas et al., 2007; Cardoso and Pentecost, 2011; Folfas, 2016; Kramar, 2016; Butkus et al., 2018) considering small-scale territories. We adopted the output approach and used the share of VA generated in industry, service and agriculture as an outcome of growth conditions created (or historically and geographically determined) in the regions. We assume that the sectoral distribution of generated VA (output) is strongly related to the availability of inputs and changes in the industry mix are not possible without alteration of inputs.

Since regions belonging to the treatment group cannot be treated equally in terms of treatment amount, we alternatively estimate the DiD interacting $d T$ with funding (treatment) intensity Tint (dedicated funds over 2000-2006 divided by GDP over the same period, see the online Appendix B). If a region did not receive funding, $d T$ and Tint, as well as their interaction, all equal 0 . If a region received funding, $d T$ equals 1 and its interaction with Tint is equal to Tint. Thus, to estimate the effect of treatment intensity, we can substitute $d T$ with Tint in Equation 4. 


\section{Estimation Results}

Our empirical examination covers all EU-25 NUTS 3 regions and consists of many estimations having three cross-sections. The first one is determined by alternative postpolicy periods. Studies at the NUTS 1 and 2 levels emphasize (but rarely, for example, Mohl and Hagen (2010), account for) that the effect of the SF may occur with a lag. This motivates us to search for the SF effect not during the policy intervention period (which could potentially be related to dummy effects due to the fact that the financial support becomes part of regional GDP), but over four post-policy periods - each of them starts in 2007, i.e., right after the 2000-2006 programming period under investigation, and ends alternatively in 2011, 2012, 2013 and 2014. Thus, we use from 5-year up to 8-year average growth rate of per capita GDP rather than a year-to-year growth rate, because averages over longer periods are less sensitive to business cycle fluctuations, which is important since the financial crisis of 2008-2009 is a part of the post-policy period. The second cross-section is determined by two alternative methods used to measure CP interventions, i.e., a binomial treatment dummy and treatment intensity. Since the results of previous papers (Rodriguez-Pose and Fratesi, 2002; Varga and Veld, 2010; Pontarollo, 2017) show that the effect of a policy intervention hinges on the intervention area and fund, the third cross-section consisting of 28 alternatives is determined by the SF under consideration and the intervention area (aims of funds and separate expenditure categories are provided in the online Appendix B). All in all, the number of estimations is equal to $4 \times 2 \times 28$, i.e., 224. Table 1 provides summarised results of the estimated parameters on control variables.

The estimated coefficients of control variables and their statistical significance do not differ much from estimation to estimation, which is a sign of robustness (see online Appendix D). The estimated convergence parameter varies from -0.32 to -1.24 and shows a negative correlation between the initial per capita GDP and growth rate over the following years, providing evidence of a slow, but still significant, $\beta$-convergence among NUTS 3 regions in the EU-25. A positive correlation between growth and working-age population shows that labour force is an important growth component and intra-country migration of young people to urban regions could form a future growth obstruction for rural areas. The estimated negative parameters on the agriculture sector show that there is a negative correlation between dependency on this sector and future growth, i.e., rural areas were growing at a slower rate compared to others. On the contrary, a bigger share of VA generated in the industry or service sectors is positively associated with future growth. The estimated parameters on industry are slightly higher compared to the ones on the service sector, but the difference is negligible and thus it is not possible 
to single out the more important sector. Capital regions are growing $1.03-1.7 \%$ p. faster on average compared to others, evidencing a positive agglomeration effect on growth. The estimated coefficients of the other factors related to regional typologies and local information were not significant, and thus not directly related to growth opportunities, but they are still important for control in our equation. The coefficients of post-policy period dummies are negative, indicating that regions were growing $2-2.5 \% \mathrm{p}$. slower over the post-policy period compared to the pre-policy period. It is not unexpected, because the financial crisis forms a part of the post-policy period.

Table 1: Summary of estimated parameters on control variables

\begin{tabular}{|c|c|c|c|c|c|}
\hline \multirow{2}{*}{ Control variable } & \multicolumn{2}{|c|}{$\begin{array}{l}\text { Range of estimated } \\
\text { parameter values }\end{array}$} & \multicolumn{2}{|c|}{$\begin{array}{l}\text { Percentage of statistically } \\
\text { significant estimates at }\end{array}$} & \multirow{2}{*}{$\begin{array}{c}\text { Percentage } \\
\text { of statistically } \\
\text { insignificant } \\
\text { estimates }\end{array}$} \\
\hline & Min & Max & $5 \%$ level & $10 \%$ level & \\
\hline Initial per capita GDP & -0.0124 & -0.0032 & 100.0 & - & - \\
\hline $\begin{array}{l}\text { Working age population } \\
\text { growth }\end{array}$ & $-4.083 e-05$ & 0.4521 & 56.7 & 9.4 & 33.9 \\
\hline $\begin{array}{l}\text { Initial share } \\
\text { of agriculture sector }\end{array}$ & -0.0017 & -0.0004 & 100.0 & - & - \\
\hline $\begin{array}{l}\text { Initial share of industry } \\
\text { sector }\end{array}$ & 0.0003 & 0.0017 & 100.0 & - & - \\
\hline $\begin{array}{l}\text { Initial share of service } \\
\text { sector }\end{array}$ & 0.0002 & 0.0015 & 97.8 & 1.3 & 0.9 \\
\hline Capital dummy & 0.0103 & 0.0170 & 100.0 & - & - \\
\hline Coastal dummy & -0.0007 & 0.0006 & - & - & 100.0 \\
\hline Port dummy & -0.0025 & -0.0003 & 24.6 & - & 75.4 \\
\hline Urban dummy & $-9.877 e-05$ & 0.0009 & - & - & 100.0 \\
\hline Rural dummy & $-9.931 e-05$ & 0.0007 & - & - & 100.0 \\
\hline
\end{tabular}

Source: Composed by authors.

Table 2 presents estimated parameters of DiD (see online Appendix D).

The estimated parameters of DiD vary greatly (in size as well as in effect direction and significance), considering different funds and expenditure categories, but the variation is small for the alternative post-policy periods (see Table 2). The estimated DiDs (in the estimations with treatment dummy) for all the funds and all the expenditure categories combined are negative and significant (the average for all the alternative post-policy periods is -0.0055$)$. It shows a negative overall effect of SF investment over the 2000-2006 policy period on regional disparities at the NUTS 3 level over 
the post-policy period. Our estimated coefficients on treatment dummies being positive show that treated were the regions which were growing faster over the pre-policy period (by approximately $0.4 \% \mathrm{p}$. compared to regions in the control group), which is not unexpected, because according to the convergence hypothesis, LDR experience faster growth rates. These findings are also confirmed by the estimates that include treatment intensity. We should stress here that $\mathrm{CP}$, which was mainly directed to address problems at the NUTS 2 level, was not appropriate to reduce imbalances on a smaller scale. We see the same negative effect on disparity dynamics when analysing estimates on ERDF Objective 1 investment (combined as well as on separate expenditure categories within this fund). Regions covered by Objective 1 are regions corresponding to the NUTS 2 level and the main aim of this financial support instrument was to promote development and structural adjustment of lagging NUTS 2 regions. Our findings suggest that these investments did not help to reduce disparities among NUTS 3 regions.

Our findings strongly support the conclusion that only ERDF Objective 2 investments, aimed to promote the social and economic conversion of NUTS 3 level regions with structural difficulties, had a positive effect reducing regional imbalances. All the estimated parameters on the DiD are positive and significant (except Human resources). The effect of investment in Human resources was estimated as insignificant (negative and significant in some cases) and the biggest positive effect was found for Productive environment and Basic infrastructure. These findings are in line with economic geography theory, which emphasizes the importance of infrastructure for transportation costs and competition and productivity for growth, and provide no evidence to support endogenous growth theory, which argues that investment in human capital is the main economic growth driver. We should add here that probably not human capital itself but the way the financial support was used to enhance human capital did not have a positive effect on growth in LDR.

Estimates with the CF (and particularly with expenditures on Basic infrastructure) provide evidence of a negative financial support effect on regional disparities at the NUTS 3 level. Objective 1 regions with a GDP of less than $90 \%$ of the EU average were eligible for support using the $\mathrm{CF}$. It financed only transport and environmental infrastructure projects, as well as technical support projects, including publicity and information campaigns. These investments did not positively contribute to the growth of NUTS 3-level LDR.

Estimates with the ERDF Urban (initiative for sustainable development in troubled urban districts) and INTEREG IIIA (whose aim was to stimulate interregional cooperation) funds provide ambiguous evidence. Almost all the estimated DiD parameters are negative, but not all are statistically significant. Thus, we cannot rigorously conclude that this kind of financial support negatively affected dynamics of the disparities at the NUTS 3 level, but on the other hand, we also see strong evidence that it had no positive effect. 
Table 2: Estimated DiD parameters

\begin{tabular}{|c|c|c|c|c|c|c|c|c|}
\hline \multirow{3}{*}{$\begin{array}{l}\text { Fund / expenditure } \\
\text { category }\end{array}$} & \multicolumn{8}{|c|}{ Estimated DiD parameters for alternative post-policy period } \\
\hline & \multicolumn{2}{|c|}{ 2007-2011 } & \multicolumn{2}{|c|}{ 2007-2012 } & \multicolumn{2}{|c|}{ 2007-2013 } & \multicolumn{2}{|c|}{$2007-2014$} \\
\hline & Td & Tint & Td & Tint & Td & Tint & Td & Tint \\
\hline All funds and all exp. cat. & $\begin{array}{c}-0.005^{* *} \\
(0.002)\end{array}$ & $\begin{array}{c}-0.007^{*} \\
(0.001)\end{array}$ & $\begin{array}{c}-0.006^{*} \\
(0.002)\end{array}$ & $\begin{array}{c}-0.010^{*} \\
(0.001)\end{array}$ & $\begin{array}{c}-0.006^{*} \\
(0.002)\end{array}$ & $\begin{array}{c}-0.011^{*} \\
(0.001)\end{array}$ & $\begin{array}{c}-0.006^{*} \\
(0.002)\end{array}$ & $\begin{array}{l}-0.010 \\
(0.001)\end{array}$ \\
\hline $\begin{array}{l}\text { 1. ERDF Objective } 1 \\
\text { (all exp. cat.) }\end{array}$ & $\begin{array}{c}-0.014^{*} \\
(0.002)\end{array}$ & $\begin{array}{c}-0.009^{*} \\
(0.001)\end{array}$ & $\begin{array}{c}-0.017^{*} \\
(0.002)\end{array}$ & $\begin{array}{c}-0.013^{*} \\
(0.001)\end{array}$ & $\begin{array}{c}-0.018^{*} \\
(0.017) \\
\end{array}$ & $\begin{array}{c}-0.015^{*} \\
(0.001) \\
\end{array}$ & $\begin{array}{c}-0.015^{*} \\
(0.002)\end{array}$ & $\begin{array}{c}-0.013^{*} \\
(0.001)\end{array}$ \\
\hline $\begin{array}{l}\text { 1.1. Productive } \\
\text { environment }\end{array}$ & $\begin{array}{c}-0.013^{*} \\
(0.002)\end{array}$ & $\begin{array}{c}-0.022^{*} \\
(0.004)\end{array}$ & $\begin{array}{c}-0.017^{*} \\
(0.002)\end{array}$ & $\begin{array}{c}-0.031^{*} \\
(0.004)\end{array}$ & $\begin{array}{c}-0.018^{*} \\
(0.002)\end{array}$ & $\begin{array}{c}-0.036^{*} \\
(0.004)\end{array}$ & $\begin{array}{l}-0.015^{*} \\
(0.002)\end{array}$ & $\begin{array}{c}-0.034^{*} \\
(0.004)\end{array}$ \\
\hline 1.2. Human resources & $\begin{array}{c}-0.019^{*} \\
(0.002)\end{array}$ & $\begin{array}{c}-0.196^{*} \\
(0.040)\end{array}$ & $\begin{array}{c}-0.022^{*} \\
(0.002)\end{array}$ & $\begin{array}{c}-0.232^{*} \\
(0.040)\end{array}$ & $\begin{array}{c}-0.021^{*} \\
(0.002)\end{array}$ & $\begin{array}{c}-0.289^{*} \\
(0.041) \\
\end{array}$ & $\begin{array}{c}-0.014^{*} \\
(0.002)\end{array}$ & $\begin{array}{l}-0.235^{*} \\
(0.037)\end{array}$ \\
\hline 1.3. Basic infrastructure & $\begin{array}{c}-0.013^{*} \\
(0.002)\end{array}$ & $\begin{array}{c}-0.013^{*} \\
(0.001)\end{array}$ & $\begin{array}{c}-0.017^{*} \\
(0.002)\end{array}$ & $\begin{array}{c}-0.017^{*} \\
(0.002)\end{array}$ & $\begin{array}{c}-0.018^{*} \\
(0.002) \\
\end{array}$ & $\begin{array}{l}-0.020^{*} \\
(0.002) \\
\end{array}$ & $\begin{array}{c}-0.015^{*} \\
(0.002)\end{array}$ & $\begin{array}{c}-0.018^{*} \\
(0.001)\end{array}$ \\
\hline 1.4. Miscellaneous & $\begin{array}{l}-0.014^{*} \\
(0.002)\end{array}$ & $\begin{array}{c}-0.448^{*} \\
(0.045)\end{array}$ & $\begin{array}{l}-0.018^{*} \\
(0.002)\end{array}$ & $\begin{array}{c}-0.553^{*} \\
(0.044)\end{array}$ & $\begin{array}{c}-0.020^{*} \\
(0.002)\end{array}$ & $\begin{array}{c}-0.607^{*} \\
(0.045)\end{array}$ & $\begin{array}{l}-0.017^{*} \\
(0.002)\end{array}$ & $\begin{array}{c}-0.494^{*} \\
(0.041)\end{array}$ \\
\hline $\begin{array}{l}\text { 2. ERDF Objective } 2 \\
\text { (all exp. cat.) }\end{array}$ & $\begin{array}{l}0.006^{*} \\
(0.002)\end{array}$ & $\begin{array}{l}0.038^{*} \\
(0.013) \\
\end{array}$ & $\begin{array}{l}0.009^{*} \\
(0.002)\end{array}$ & $\begin{array}{l}0.052^{*} \\
(0.013)\end{array}$ & $\begin{array}{l}0.009^{*} \\
(0.002)\end{array}$ & $\begin{array}{l}0.051^{*} \\
(0.014)\end{array}$ & $\begin{array}{l}0.007^{*} \\
(0.002)\end{array}$ & $\begin{array}{l}0.052^{*} \\
(0.012) \\
\end{array}$ \\
\hline $\begin{array}{l}\text { 2.1. Productive } \\
\text { environment }\end{array}$ & $\begin{array}{l}0.006^{*} \\
(0.002)\end{array}$ & $\begin{array}{l}0.066^{*} \\
(0.019) \\
\end{array}$ & $\begin{array}{l}0.008^{*} \\
(0.002)\end{array}$ & $\begin{array}{l}0.080^{*} \\
(0.019)\end{array}$ & $\begin{array}{l}0.009^{*} \\
(0.002)\end{array}$ & $\begin{array}{l}0.084^{*} \\
(0.019) \\
\end{array}$ & $\begin{array}{l}0.007^{*} \\
(0.002)\end{array}$ & $\begin{array}{l}0.083^{*} \\
(0.018)\end{array}$ \\
\hline 2.2. Human resources & $\begin{array}{c}-0.005^{* *} \\
(0.002)\end{array}$ & $\begin{array}{c}-0.707^{*} \\
(0.269)\end{array}$ & $\begin{array}{l}-0.004 \\
(0.002)\end{array}$ & $\begin{array}{c}-0.564^{* *} \\
(0.269) \\
\end{array}$ & $\begin{array}{l}-0.003 \\
(0.002)\end{array}$ & $\begin{array}{l}-0.332 \\
(0.274)\end{array}$ & $\begin{array}{l}-0.002 \\
(0.002)\end{array}$ & $\begin{array}{l}-0.159 \\
(0.249)\end{array}$ \\
\hline 2.3. Basic infrastructure & $\begin{array}{l}0.005^{*} \\
(0.002)\end{array}$ & $\begin{array}{c}0.044 \\
(0.033)\end{array}$ & $\begin{array}{l}0.007^{*} \\
(0.002)\end{array}$ & $\begin{array}{l}0.082^{* *} \\
(0.033)\end{array}$ & $\begin{array}{l}0.007^{*} \\
(0.002)\end{array}$ & $\begin{array}{c}0.058^{* * *} \\
(0.034)\end{array}$ & $\begin{array}{l}0.005^{*} \\
(0.002)\end{array}$ & $\begin{array}{l}0.065^{* *} \\
(0.031)\end{array}$ \\
\hline 2.4. Miscellaneous & $\begin{array}{c}0.002 \\
(0.002) \\
\end{array}$ & $\begin{array}{c}0.484 \\
(0.324) \\
\end{array}$ & $\begin{array}{l}0.005^{*} \\
(0.002)\end{array}$ & $\begin{array}{l}0.899^{*} \\
(0.325)\end{array}$ & $\begin{array}{l}0.005^{*} \\
(0.002) \\
\end{array}$ & $\begin{array}{l}0.677^{* * *} \\
(0.330)\end{array}$ & $\begin{array}{l}0.004^{*} \\
(0.002)\end{array}$ & $\begin{array}{l}0.805^{*} \\
(0.299) \\
\end{array}$ \\
\hline $\begin{array}{l}\text { 3. Cohesion fund } \\
\text { (all exp. cat.) }\end{array}$ & $\begin{array}{l}-0.013^{*} \\
(0.002)\end{array}$ & $\begin{array}{c}-0.008^{*} \\
(0.003) \\
\end{array}$ & $\begin{array}{c}-0.022^{*} \\
(0.002) \\
\end{array}$ & $\begin{array}{l}-0.016^{*} \\
(0.003)\end{array}$ & $\begin{array}{c}-0.023^{*} \\
(0.002) \\
\end{array}$ & $\begin{array}{c}-0.014^{*} \\
(0.003) \\
\end{array}$ & $\begin{array}{l}-0.017^{*} \\
(0.002)\end{array}$ & $\begin{array}{c}-0.012^{*} \\
(0.003) \\
\end{array}$ \\
\hline 3.3. Basic infrastructure & $\begin{array}{l}-0.013^{*} \\
(0.002)\end{array}$ & $\begin{array}{c}-0.008^{*} \\
(0.003)\end{array}$ & $\begin{array}{l}-0.022^{*} \\
(0.002)\end{array}$ & $\begin{array}{l}-0.017^{*} \\
(0.003)\end{array}$ & $\begin{array}{c}-0.023^{*} \\
(0.002)\end{array}$ & $\begin{array}{c}-0.015^{*} \\
(0.003)\end{array}$ & $\begin{array}{l}-0.017^{*} \\
(0.002)\end{array}$ & $\begin{array}{c}-0.013^{*} \\
(0.003)\end{array}$ \\
\hline 3.4. Miscellaneous & $\begin{array}{c}0.004 \\
(0.003) \\
\end{array}$ & $\begin{array}{c}0.273^{* * *} \\
(0.139) \\
\end{array}$ & $\begin{array}{l}-0.002 \\
(0.003) \\
\end{array}$ & $\begin{array}{c}0.126 \\
(0.140) \\
\end{array}$ & $\begin{array}{c}-0.006^{* *} \\
(0.003)\end{array}$ & $\begin{array}{l}0.427^{*} \\
(0.142) \\
\end{array}$ & $\begin{array}{c}-0.005^{* * *} \\
(0.003) \\
\end{array}$ & $\begin{array}{l}0.390^{*} \\
(0.128) \\
\end{array}$ \\
\hline $\begin{array}{l}\text { 4. Urban } \\
\text { (all exp. cat.) }\end{array}$ & $\begin{array}{l}-0.004 \\
(0.003) \\
\end{array}$ & $\begin{array}{l}-0.096 \\
(0.119) \\
\end{array}$ & $\begin{array}{c}-0.006^{* * *} \\
(0.003) \\
\end{array}$ & $\begin{array}{l}-0.138 \\
(0.119) \\
\end{array}$ & $\begin{array}{c}-0.009^{*} \\
(0.003) \\
\end{array}$ & $\begin{array}{c}-0.271^{* *} \\
(0.120) \\
\end{array}$ & $\begin{array}{c}-0.008^{*} \\
(0.003) \\
\end{array}$ & $\begin{array}{c}-0.229^{* *} \\
(0.109) \\
\end{array}$ \\
\hline $\begin{array}{l}\text { 4.1. Productive } \\
\text { environment }\end{array}$ & $\begin{array}{l}-0.002 \\
(0.004)\end{array}$ & $\begin{array}{c}0.200 \\
(0.577) \\
\end{array}$ & $\begin{array}{l}-0.004 \\
(0.004)\end{array}$ & $\begin{array}{c}0.484 \\
(0.577) \\
\end{array}$ & $\begin{array}{c}-0.008^{* *} \\
(0.004)\end{array}$ & $\begin{array}{l}-0.086 \\
(0.587) \\
\end{array}$ & $\begin{array}{c}-0.008^{* *} \\
(0.003) \\
\end{array}$ & $\begin{array}{l}-0.153 \\
(0.532)\end{array}$ \\
\hline 4.2. Human resources & $\begin{array}{l}-0.005 \\
(0.003) \\
\end{array}$ & $\begin{array}{l}-0.607 \\
(0.879) \\
\end{array}$ & $\begin{array}{c}-0.007^{* *} \\
(0.004) \\
\end{array}$ & $\begin{array}{l}-0.474 \\
(0.881) \\
\end{array}$ & $\begin{array}{c}-0.009 * * \\
(0.004)\end{array}$ & $\begin{array}{l}-0.971 \\
(0.895) \\
\end{array}$ & $\begin{array}{c}-0.009^{*} \\
(0.003) \\
\end{array}$ & $\begin{array}{l}-1.053 \\
(0.811) \\
\end{array}$ \\
\hline 4.3. Basic infrastructure & $\begin{array}{l}-0.005 \\
(0.003)\end{array}$ & $\begin{array}{l}-0.160 \\
(0.162) \\
\end{array}$ & $\begin{array}{c}-0.006^{* * *} \\
(0.003)\end{array}$ & $\begin{array}{l}-0.262 \\
(0.162) \\
\end{array}$ & $\begin{array}{c}-0.009^{*} \\
(0.003)\end{array}$ & $\begin{array}{l}-0.435^{*} \\
(0.164)\end{array}$ & $\begin{array}{c}-0.008^{*} \\
(0.003)\end{array}$ & $\begin{array}{c}-0.352^{* *} \\
(0.149)\end{array}$ \\
\hline 4.4. Miscellaneous & $\begin{array}{l}-0.004 \\
(0.003) \\
\end{array}$ & $\begin{array}{l}-2.077 \\
(1.949) \\
\end{array}$ & $\begin{array}{c}-0.006^{* * *} \\
(0.003) \\
\end{array}$ & $\begin{array}{l}-2.447 \\
(1.952) \\
\end{array}$ & $\begin{array}{c}-0.009^{* *} \\
(0.003) \\
\end{array}$ & $\begin{array}{c}-4.367^{* *} \\
(1.982 \\
\end{array}$ & $\begin{array}{c}-0.009^{*} \\
(0.003)\end{array}$ & $\begin{array}{c}-3.963^{* *} \\
(1.799) \\
\end{array}$ \\
\hline $\begin{array}{l}\text { 5. ERDF INTERREG IIIA } \\
\text { (all exp. cat.) }\end{array}$ & $\begin{array}{l}-0.001 \\
(0.002)\end{array}$ & $\begin{array}{c}-0.040^{* *} \\
(0.020)\end{array}$ & $\begin{array}{c}-0.004^{* *} \\
(0.002) \\
\end{array}$ & $\begin{array}{l}-0.077^{*} \\
(0.020)\end{array}$ & $\begin{array}{l}-0.002 \\
(0.002)\end{array}$ & $\begin{array}{c}-0.104^{*} \\
(0.020) \\
\end{array}$ & $\begin{array}{r}-0.002 \\
(0.002)\end{array}$ & $\begin{array}{l}-0.082^{*} \\
(0.018)\end{array}$ \\
\hline $\begin{array}{l}\begin{array}{l}\text { 5.1. Productive } \\
\text { environment }\end{array} \\
\end{array}$ & $\begin{array}{l}-0.001 \\
(0.002) \\
\end{array}$ & $\begin{array}{c}0.023 \\
(0.044) \\
\end{array}$ & $\begin{array}{c}-0.004^{* *} \\
(0.002) \\
\end{array}$ & $\begin{array}{l}-0.022 \\
(0.044) \\
\end{array}$ & $\begin{array}{l}-0.002 \\
(0.002) \\
\end{array}$ & $\begin{array}{l}-0.061 \\
(0.045) \\
\end{array}$ & $\begin{array}{l}-0.002 \\
(0.002) \\
\end{array}$ & $\begin{array}{l}-0.052 \\
(0.041) \\
\end{array}$ \\
\hline 5.2. Human resources & $\begin{array}{l}-0.001 \\
(0.002)\end{array}$ & $\begin{array}{l}-0.308 \\
(0.321) \\
\end{array}$ & $\begin{array}{c}-0.003^{* * *} \\
(0.002) \\
\end{array}$ & $\begin{array}{c}-0.625^{* * *} \\
(0.322) \\
\end{array}$ & $\begin{array}{l}-0.001 \\
(0.002)\end{array}$ & $\begin{array}{c}-0.849^{*} \\
(0.327)\end{array}$ & $\begin{array}{l}-0.001 \\
(0.002)\end{array}$ & $\begin{array}{c}-0.639 * * \\
(0.297)\end{array}$ \\
\hline 5.3. Basic infrastructure & $\begin{array}{l}-0.001 \\
(0.002) \\
\end{array}$ & $\begin{array}{c}-0.142^{*} \\
(0.036) \\
\end{array}$ & $\begin{array}{c}-0.004^{* *} \\
(0.002) \\
\end{array}$ & $\begin{array}{c}-0.226^{*} \\
(0.036) \\
\end{array}$ & $\begin{array}{l}-0.002 \\
(0.002) \\
\end{array}$ & $\begin{array}{c}-0.280^{*} \\
(0.037) \\
\end{array}$ & $\begin{array}{l}-0.002 \\
(0.002) \\
\end{array}$ & $\begin{array}{c}-0.218^{*} \\
(0.033) \\
\end{array}$ \\
\hline 5.4. Miscellaneous & $\begin{array}{l}-0.001 \\
(0.002) \\
\end{array}$ & $\begin{array}{l}-0.161 \\
(0.242) \\
\end{array}$ & $\begin{array}{c}-0.004^{* *} \\
(0.002) \\
\end{array}$ & $\begin{array}{c}-0.600 * * \\
(0.242) \\
\end{array}$ & $\begin{array}{l}-0.002 \\
(0.002) \\
\end{array}$ & $\begin{array}{l}-0.947^{*} \\
(0.245) \\
\end{array}$ & $\begin{array}{l}-0.002 \\
(0.002) \\
\end{array}$ & $\begin{array}{l}-0.839 * \\
(0.223)\end{array}$ \\
\hline $\begin{array}{l}\text { Productive environment } \\
\text { (all funds ERDF+CF) }\end{array}$ & $\begin{array}{c}-0.005^{* *} \\
(0.002) \\
\end{array}$ & $\begin{array}{c}-0.019^{*} \\
(0.004)\end{array}$ & $\begin{array}{l}-0.006^{*} \\
(0.002)\end{array}$ & $\begin{array}{l}-0.028^{*} \\
(0.004)\end{array}$ & $\begin{array}{c}-0.007^{*} \\
(0.002)\end{array}$ & $\begin{array}{c}-0.033^{*} \\
(0.004) \\
\end{array}$ & $\begin{array}{l}-0.006^{*} \\
(0.002)\end{array}$ & $\begin{array}{c}-0.031^{*} \\
(0.004)\end{array}$ \\
\hline $\begin{array}{l}\text { Human resources } \\
\text { (all funds ERDF+CF) }\end{array}$ & $\begin{array}{c}-0.008^{*} \\
(0.002)\end{array}$ & $\begin{array}{c}-0.209^{*} \\
(0.039)\end{array}$ & $\begin{array}{l}-0.009^{*} \\
(0.002)\end{array}$ & $\begin{array}{l}-0.244^{*} \\
(0.040)\end{array}$ & $\begin{array}{l}-0.008^{*} \\
(0.002)\end{array}$ & $\begin{array}{l}-0.298^{*} \\
(0.040)\end{array}$ & $\begin{array}{l}-0.006^{*} \\
(0.002)\end{array}$ & $\begin{array}{l}-0.240^{*} \\
(0.036)\end{array}$ \\
\hline $\begin{array}{l}\text { Basic infrastructure } \\
\text { (all funds ERDF+CF) }\end{array}$ & $\begin{array}{c}-0.005^{* *} \\
(0.002) \\
\end{array}$ & $\begin{array}{c}-0.008^{*} \\
(0.001) \\
\end{array}$ & $\begin{array}{l}-0.006^{*} \\
(0.002)\end{array}$ & $\begin{array}{c}-0.012^{*} \\
(0.001) \\
\end{array}$ & $\begin{array}{c}-0.007^{*} \\
(0.002) \\
\end{array}$ & $\begin{array}{c}-0.014^{*} \\
(0.001) \\
\end{array}$ & $\begin{array}{l}-0.007^{*} \\
(0.002)\end{array}$ & $\begin{array}{c}-0.012^{*} \\
(0.001)\end{array}$ \\
\hline $\begin{array}{l}\text { Miscellaneous } \\
\text { (all funds ERDF+CF) }\end{array}$ & $\begin{array}{c}-0.008^{*} \\
(0.002)\end{array}$ & $\begin{array}{c}-0.354^{*} \\
(0.042)\end{array}$ & $\begin{array}{l}-0.009^{*} \\
(0.002)\end{array}$ & $\begin{array}{c}-0.464^{*} \\
(0.041)\end{array}$ & $\begin{array}{c}-0.010^{*} \\
(0.002)\end{array}$ & $\begin{array}{l}-0.498^{*} \\
(0.042)\end{array}$ & $\begin{array}{l}-0.008^{*} \\
(0.002)\end{array}$ & $\begin{array}{c}-0.398^{*} \\
(0.038)\end{array}$ \\
\hline
\end{tabular}

Notes: Td - estimates with treatment dummy, Tint - with treatment intensity, exp. cat. - expenditure category. The top figures are estimated $\mathrm{DiD}$, the bottom figures report the robust standard errors. ${ }^{* * *},{ }^{* *},{ }^{*}$ indicate statistically significant estimates at $10 \%, 5 \%$ and $1 \%$ levels, respectively. The table reports only estimated parameters of DiD retrieved from estimations presented in online Appendix D.

Source: Composed by authors. 
The last four rows in Table 1 are for DiD parameters on the separate expenditure category combining all the funds. All the estimated parameters are negative and statistically significant, giving evidence that the financial support had a negative effect on the dynamics of disparities at the NUTS 3 level. Despite the strong positive effect of the ERDF Objective 2 investment, the amount of investment targeted to NUTS 2 outweighs the investment targeted to NUTS 3 (see online Appendix B for funding intensity) and the negative effect of the former outbalances the positive effect of the latter.

For the robustness check, we re-estimated our model for the 2009-2014 and 2010-2014 post-policy periods keeping the same sample (see Table E1 in on-line Appendix E) to minimise the effect of the financial crisis on the outcome variable. The general findings did not change. The results of the re-estimated model without PIIGS and the Baltics for the general post-policy periods (see Table E2) show the same direction of the impact, but the estimated parameter on DiD, i.e., the effect on disparities, is smaller and less significant. The estimations without the least and the most funded regions (see Table E3), keeping the general post-policy periods, yield the same results as the general ones.

Having this evidence, we can argue that SF financial support, mainly directed to NUTS 2 regions, has a negative externality - it increases disparities among NUTS 3 regions, probably due to support concentration in a few NUTS 3 regions within NUTS 2 regions.

\section{Conclusions and Policy Implications}

The analysis of previous papers on regional growth and convergence revealed three main theoretical approaches commonly used to model the return on SF - neoclassical and endogenous growth theories and new economic geography. Although each of the three approaches emphasizes different growth forces, the majority of empirical research combines them, perceiving that one or two factors cannot explain all the dynamics of regional growth. Almost all the empirical studies that examine the question "What is the return on investment to support regional performance using ERDF and CF funds?" focus on growth effects of financial support and mainly test these effects on NUTS 1 and 2 regions.

The aim of our research was to analyse what effect financial support has on convergence dynamics at the NUTS 3 level because studies that have decomposed disparities in the EU have highlighted that the share of disparities attributed to the NUTS 3 level has increased over the last two decades. Aiming to empirically examine this outcome of the CP, we proposed a model that combines a conditional $\beta$-convergence approach and a $\mathrm{DiD}$ estimator. The estimation results revealed that SF funding over the 2000-2006 programming 
period had an overall negative effect on convergence dynamics at the NUTS 3 level over the post-policy period. This is also supported by the evidence provided by estimations on separate funds (ERDF Objective 1 and $\mathrm{CF}$ ) primarily directed to address problems in NUTS 2 regions. We found that only ERDF Objective 2, which aims to support structural conversion in NUTS 3 regions, contributed positively to convergence among them. We also found that only investment to support Basic infrastructure and Productive environment within the ERDF Objective 2 fund had a positive return. This evidence brings to light the question of potential negative outcomes of existing CP in the EU. Our findings support the hypothesis that regional policy, which is focused on NUTS 2 regions, is enlarging imbalances within these regions, i.e., among NUTS 3 regions. The distribution of finances at the NUTS 2 level does not guarantee that support will reach the NUTS 3 regions that mostly need this support. Therefore, despite the fact that the majority of SF financial support is directed to solve problems arising in NUTS 2 regions, policymakers should make an attempt to introduce measures for distribution of support within NUTS 2 regions in a way that will not lead to growth in disparities at the NUTS 3 level.

We would like to highlight here some limitations of our research that were beyond the aim of our study but should be kept in mind when evaluating growth and convergence at the NUTS 3 level. Examining effects of financial support by fund and expenditure category, our research does not consider that the effect might also depend on countryspecific factors (i.e., differences between new and old MS, between countries with good and bad institutions, etc.) and that part of the effect can have the form of a positive spill-over. Estimating the effect over the post-policy period using 5-8 year averages does not necessarily diminish the possibility that a huge strategic project which was started in the last years of the programming period will have an effect over a much longer post-policy period compared to those considered (due to data limitations) by our research. All the alternative post-policy periods under consideration start in 2007, i.e., right after the programming period, and they all cover the years of the Great Financial Crisis. Averaging the growth rates over 5-8 year periods diminishes, but does not eliminate, the effect of business cycles on the outcome. Since NUTS 3 regions are small entities, there is always a threat that research results could be affected to some extent by measurement issues. For example, GDP at the NUTS 3 level is estimated rather than calculated (as well as the amount of ERDF and CF funding, see online Appendix C). It is also likely that some part of the GDP at the NUTS 3 level is assignable to commuters and it becomes inaccurate to use per capita GDP as a proxy for the per capita income as well as to measure working-age population using local demographic statistics. 


\section{References}

Accetturo, A., de Blasio, G., Ricci, L. (2014). A Tale of Unwanted Outcome: Transfers and Local Endowments of Trust and Cooperation. Journal of Economic Behavior \& Organization, 102, 74-89, https://doi.org/10.1016/j.jebo.2014.03.015

Barro, R. J., Sala-I-Martin, X., Blanchard, O. J., Hall, R. E. (1991). Convergence across States and Regions. Brookings Papers on Economic Activity, 22(1), 107-182, https://doi.org/10.2307/2534639

Barro, R. J., Sala-i-Martin, X. (1992). Convergence. Journal Political Economy, 100(2), 223-251, https://doi.org/10.1086/261816

Becker, S., Egger, P. H., Von Ehrlich, M. (2010). Going NUTS: The Effect of EU Structural funds on Regional Performance. Journal of Public Economics, 94(9-10), 578-590, https://doi.org/10.1016/j.jpubeco.2010.06.006

Becker, S., Egger, P. H., Von Ehrlich, M. (2012). Too Much of a Good Thing? On the growth effects of the EU's regional policy. European Economic Review, 56(4), 648-668, https://doi.org/10.1016/j.euroecorev.2012.03.001

Becker, S., Egger, P. H., Von Ehrlich, M. (2013). Absorptive Capacity and the Growth Effects of Regional Transfers: a Regression Discontinuity Design with Heterogeneous Treatment Effects. American Economic Journal: Economic Policy, 5(4), 29-77, https://doi.org/10.1257/pol.5.4.29

Becker, S., Egger, P. H., Von Ehrlich, M. (2018). Effects of EU Regional Policy: 1989-2013. Regional Science and Urban Economics, 69, 143-152, https://doi.org/10.1016/j. regsciurbeco.2017.12.001

Bourdin, S. (2015). National and Regional Trajectories of Convergence and Economic Integration in Central and Eastern Europe. Canadian Journal of Regional Science, 38, 55-63.

Butkus, M., Cibulskiene, D., Maciulyte-Sniukiene, A., Matuzeviciute, K. (2018). What Is the Evolution of Convergence in the EU? Decomposing EU Disparities up to NUTS 3 Level. Sustainability, 10(5), https://doi.org/10.3390/su10051552

Cardoso, C., Pentecost, E. J. (2011). Regional Growth and Convergence: The Role of Human Capital in Portuguese Regions. Loughborough University. Working Paper 2011-3, pp. 1-28.

Di Cataldo, M. (2017). The Impact of EU Objective 1 Funds on Regional Development: Evidence from the UK and the Prospect of Brexit. Journal of Regional Science, 57(5), 814-839, https://doi.org/10.1111/jors.12337

Dotti, N. F. (2016). Unwritten Factors Affecting Structural Funds: The Influence of Regional Political Behaviours on the Implementation of EU Cohesion Policy. European Planning Studies, 24(3), 530-550, https://doi.org/10.1080/09654313.2015.1047328

Folfas, P. (2016). Income Absolute Beta-Convergence of NUTS 3 Level Regions in New EU Member States Before and During a Crisis. Folia Oeconomica Stetinensia, 16(2), 151-162, https://doi.org/10.1515/foli-2016-0031 
Fratesi, P., Perucca, G. (2014). Territorial Capital and the Effectiveness of Cohesion Policies: an Assessment for CEE Regions. GRINCOH. Working Paper Series No. 8.05.

Fujita, M., Krugman, P., Venables, A. J. (1999). The Spatial Economy: Cities, Regions and International Trade. Cambridge, MA: MIT Press. ISBN 9780262062046.

Gagliardi, L., Percoco, M. (2017). The Impact of European Cohesion Policy in Urban and Rural Regions. Regional Studies, 51(6), 857-868, https://doi.org/10.1080/00343404.2016.1179384

Hegerty, S. W. (2016). Regional Convergence and Growth Clusters in Central and Eastern Europe: An Examination of Sectoral-Level Data. Eastern European Business and Economics Journal, 2(2), 95-110.

Kramar, H. (2016). Regional Convergence and Economic Development in the EU: The Relation between National Growth and Regional Disparities within the Old and the New Member States. International Journal of Latest Trends in Finance \& Economic Sciences, 6(1), 1052-1062.

Kutan, A. M.; Yigit, T. M. (2007). European Integration, Productivity Growth and Real Convergence. European Economic Review, 51(6), 1370-1395, https://doi.org/10.1016/j. euroecorev.2006.11.001

Kyriacou, A. P., Roca-Sagalés, O. (2012). The Impact of EU Structural Funds on Regional Disparities within Member States. Environment and Planning C: Politics and Space, 30(2), 267-281, https://doi.org/10.1068/c11140r

Mankiw, G. N., Romer, D., Weil, D. N. (1992). A Contribution to the Empirics of Economic Growth. Quarterly Journal of Economics, 107(2), 407-437, https://doi.org/10.2307/2118477

Mohl, P., Hagen, T. (2010). Do EU Structural Funds Promote Regional Growth? New Evidence from Various Panel Data Approaches. Regional Science and Urban Economics, 40(5), 353-365, https://doi.org/10.1016/j.regsciurbeco.2010.03.005

Paas, T., Kuusk, A., Schlitte, F., Võrk, A. (2007). Econometric Analysis of Income Convergence in Selected EU Countries and Their Nuts 3 Level Regions. University of Tartu. Tartu, Estonia Working Paper No. 60-2007, https://doi.org/10.2139/ssrn.1078863

Pellegrini, G., Cerqua, A. (2016). Measuring the Impact of Intensity of Treatment Using RDD and Covariates: the Case of Structural Funds. $57^{\text {th }}$ RSA Annual Conference, Bocconi University, 20-22 October, 2016.

Pellegrini, G., Terrible, F., Tarola, O., Muccigrosse, T., Busillo, F. (2013). Measuring the Effects of European Regional Policy on Economic Growth: A Regression Discontinuity Approach. Papers in Regional Science, 92(1), 217-233, https://doi.org/10.1111/j.1435-5957.2012.00459.x

Percoco, M. (2017). Impact of European Cohesion Policy on Regional Growth: Does Local Economic Structure Matter? Regional Studies, 51(6), 833-843, https://doi.org/10.1080/003 43404.2016.1213382

Pinho, C., Varum, C., Antunes, M. (2015a). Under What Conditions Do Structural Funds Play a Significant Role in European Regional Economic Growth? Some Evidence from Recent Panel Data. Journal of Economic Issues, 49(3), 749-771, https://doi.org/10.1080/00213624.2015.1072382 
Pinho, C., Varum, C., Anutes, M. (2015b). Structural Funds and European Regional Growth: Comparison of Effects among Different Programming Periods. European Planning Studies, 23(7), 1302-1326, https://doi.org/10.1080/09654313.2014.928674

Pontarollo, N. (2017). Does Cohesion Policy Affect Regional Growth? New Evidence from a Semi-parametric Approach, in Bachtler, J., Berkowitz, P., Hardy, S., Muravska, T., eds., EU Cohesion Policy: Reassessing Performance and Direction. Abingdon: Routledge, pp. 69-84.

Rodriguez-Pose, A., Fratesi, U. (2002). Unbalanced Development Strategies and the Lack of Regional Convergence in the EU. Paper Presented at 42nd Congress of the European Regional Science Association: “From Industry to Advanced Services - Perspectives of European Metropolitan Regions", 27-31 August, 2002, Dortmund, Germany.

Rodriguez-Pose, A., Garcilazo, E. (2015). Quality of Government and the Returns of Investment: Examining the Impact of Cohesion Expenditure in European Regions. Regional Studies, 49(8), 1274-1290, https://doi.org/10.1080/00343404.2015.1007933

Rodriguez-Pose, A., Novak, K. (2013). Learning Processes and Economic Returns in European Cohesion Policy. Investigaciones Regionales, 25, 7-26.

Romer, P. M. (1990). Endogenous Technological Change. Journal of Political Economy, 98(5), S71-S102, https://doi.org/10.1086/261725

Romer, P. M. (1994). The Origins of Endogenous Growth. The Journal of Economic Perspectives, 8(1), 3-22, https://doi.org/10.1257/jep.8.1.3

Smetkowski, M., Wójcik, P. (2012). Regional Convergence in Central and Eastern European Countries: A Multidimensional Approach. European Planning Studies, 20(6), 923-939, https://doi.org/10.1080/09654313.2012.673560

Solow, R. M. (1956). A Contribution to the Theory of Economic Growth. Quarterly Journal of Economics, 70(1), 65-94, https://doi.org/10.2307/1884513

Swan, T. W. (1956). Economic Growth and Capital Accumulation. Economic Record, 32(2), 334-361, https://doi.org/10.1111/j.1475-4932.1956.tb00434.x

Varga, J., Veld, J. (2010). A Model-Based Analysis of the Impact of Cohesion Policy Expenditure 2000-06: Simulations with QUEST III Endogenous R\&D Model. Economic Modelling, 28(1-2), 647-663, https://doi.org/10.1016/j.econmod.2010.06.004

Vickerman, R., Spiekermann, K., Wegner, M. (1999). Accessibility and Economic Development in Europe. Regional Studies, 33(1), 1-15, https://doi.org/10.1080/00343409950118878 
Appendix A

Table A1. Main results of previous literature on SF effects

\begin{tabular}{|c|c|c|c|c|c|}
\hline Research by & $\begin{array}{c}\text { Covered } \\
\text { period }\end{array}$ & Units & $\begin{array}{c}\text { Econometric } \\
\text { method applied }\end{array}$ & $\begin{array}{l}\text { Outcome } \\
\text { variable }\end{array}$ & Main result \\
\hline $\begin{array}{l}\text { Becker et al. } \\
(2010)\end{array}$ & $\begin{array}{l}1989-1993 \\
1994-1999 \\
2000-2006\end{array}$ & $\begin{array}{l}\text { NUTS2 }(193-285) \\
\text { and NUTS3 } \\
(1015-1213) \\
\text { regions (EU-25) }\end{array}$ & $\begin{array}{l}\text { Cross sectional and } \\
\text { panel: difference- } \\
\text { in-difference } \\
\text { regression } \\
\text { discontinuity design } \\
\text { (DID-RDD) }\end{array}$ & $\begin{array}{l}\text { Economic and } \\
\text { employment } \\
\text { growth }\end{array}$ & $\begin{array}{l}\text { Small and positive impact on economic } \\
\text { growth, which is robust to period } \\
\text { choice and estimation methods, applied. } \\
\text { The significant positive effect } \\
\text { on employment appears only } \\
\text { in the 2000-2006 programming period }\end{array}$ \\
\hline $\begin{array}{l}\text { Mohl and } \\
\text { Hagen (2010) }\end{array}$ & 2000-2006 & $\begin{array}{l}126 \text { NUTS-1/ } \\
\text { NUTS-2 regions } \\
\text { (EU-6) }\end{array}$ & $\begin{array}{l}\text { Spatial econometric } \\
\text { estimator, GMM } \\
\text { estimator }\end{array}$ & $\begin{array}{l}\text { Economic } \\
\text { growth }\end{array}$ & $\begin{array}{l}\text { Positive and statistically significant impact } \\
\text { on the economic growth. Regional } \\
\text { spillovers do have a significant impact } \\
\text { on the regional growth rates irrespective } \\
\text { of which Objective and time lag is analysed }\end{array}$ \\
\hline $\begin{array}{l}\text { Kyriacou, } \\
\text { Roca-Sagalés } \\
(\mathbf{2 0 1 2})\end{array}$ & $\begin{array}{l}1994-1999 \\
\text { and } 2000- \\
2006\end{array}$ & $\begin{array}{l}14 \text { EU countries } \\
\text { Country-level }\end{array}$ & $\begin{array}{l}\text { Feasible General } \\
\text { Least Squares } \\
\text { (FGLS), Seemingly } \\
\text { Unrelated } \\
\text { Regression (SUR) } \\
\end{array}$ & Convergence & $\begin{array}{l}\text { Positive impact on convergence and } \\
\text { depends on the level of transfer intensity }\end{array}$ \\
\hline $\begin{array}{l}\text { Becker et al. } \\
(2013)\end{array}$ & $\begin{array}{l}1989-1993 \\
1994-1999 \\
2000-2006\end{array}$ & $\begin{array}{l}\text { 186-251 NUTS } 2 \\
\text { regions (EU-25) }\end{array}$ & $\begin{array}{l}\text { Cross sectional: } \\
\text { a fuzzy regression } \\
\text { discontinuity design } \\
\text { (RDD)+HLATE }\end{array}$ & $\begin{array}{l}\text { Economic } \\
\text { growth }\end{array}$ & $\begin{array}{l}\text { Positive impact on economic growth only } \\
\text { on about } 30 \% \text { of the regions. While } \\
\text { the treatment effect is insignificant } \\
\text { for regions with a very low level } \\
\text { of absorptive capacity. }\end{array}$ \\
\hline $\begin{array}{l}\text { Pellegrini et al. } \\
(2013)\end{array}$ & $\begin{array}{l}1994-1999 \\
2000-2006\end{array}$ & $\begin{array}{l}\text { NUTS-2 regions } \\
\text { (EU-15) }\end{array}$ & $\begin{array}{l}\text { Regression } \\
\text { discontinuity design } \\
\text { (RDD) }\end{array}$ & $\begin{array}{l}\text { Economic } \\
\text { growth }\end{array}$ & Positive impact on economic growth. \\
\hline $\begin{array}{l}\text { Rodriguez- } \\
\text { Pose and } \\
\text { Novak (2013) }\end{array}$ & $\begin{array}{l}1994-1999 \\
\text { and } \\
2000-2006\end{array}$ & $\begin{array}{l}133(\text { EU15) } \\
\text { NUTS-1/NUTS-2 } \\
\text { regions }\end{array}$ & $\begin{array}{l}\text { Heteroscedasticity- } \\
\text { robust fixed effects }\end{array}$ & $\begin{array}{l}\text { Economic } \\
\text { growth }\end{array}$ & $\begin{array}{l}\text { Impact of SF on economic growth is } \\
\text { insignificant }\end{array}$ \\
\hline $\begin{array}{l}\text { Accetturo et al. } \\
(2014)\end{array}$ & $2000-2006$ & NUTS-2 level & $\begin{array}{l}\text { Regression } \\
\text { discontinuity design } \\
\text { (RDD) }\end{array}$ & $\begin{array}{l}\text { Local } \\
\text { endowments } \\
\text { of trust and } \\
\text { cooperation }\end{array}$ & $\begin{array}{l}\text { The transfers reduce local endowments } \\
\text { of trust and cooperation. }\end{array}$ \\
\hline $\begin{array}{l}\text { Fratesi and } \\
\text { Perucca }(2014)\end{array}$ & 2004-2006 & $\begin{array}{l}\text { NUTS- } 3 \text { regions } \\
\text { (10 CEE countries) }\end{array}$ & $\begin{array}{l}\text { Ordinary Least } \\
\text { Squares (OLS) }\end{array}$ & $\begin{array}{l}\text { Economic } \\
\text { growth }\end{array}$ & $\begin{array}{l}\text { Regional policy is not much effective } \\
\text { per se, but effectiveness depend } \\
\text { on "territorial capital". }\end{array}$ \\
\hline $\begin{array}{l}\text { Pihno et al. } \\
\text { (2015a) }\end{array}$ & $\begin{array}{l}1995-1999 \\
2000-2006 \\
\text { and } \\
2007-2009\end{array}$ & $\begin{array}{l}92 \text { EU } 12 \text { NUTS } 1 \\
\text { and NUTS } 2 \\
\text { regions }\end{array}$ & $\begin{array}{l}\text { Growth model } \\
\text { by FE with Driscoll } \\
\text { and Kraay's } \\
\text { correction }\end{array}$ & $\begin{array}{l}\text { Economic } \\
\text { growth }\end{array}$ & $\begin{array}{l}\text { Positive impact on economic growth } \\
\text { in richer, highly-educated and more } \\
\text { innovative regions }\end{array}$ \\
\hline $\begin{array}{l}\text { Rodriguez- } \\
\text { Pose and } \\
\text { Garcilazo } \\
\text { (2015) }\end{array}$ & 1996-2007 & $\begin{array}{l}169 \text { European } \\
\text { NUTS-1/NUTS-2 } \\
\text { regions }\end{array}$ & $\begin{array}{l}\text { Two-way fixed } \\
\text { effect panel } \\
\text { regression model }\end{array}$ & $\begin{array}{l}\text { Economic } \\
\text { growth }\end{array}$ & $\begin{array}{l}\text { Positive impact on regional economic } \\
\text { growth, but that above a threshold } \\
\text { of cohesion expenditure }\end{array}$ \\
\hline Dotti (2016) & $2000-2006$ & $\begin{array}{l}\text { NUTS } 2 \text { regions } \\
\text { in France, Italy and } \\
\text { Spain; and NUTS } \\
1 \text { in Germany } \\
\text { and UK }\end{array}$ & Correlation analysis & $\begin{array}{l}\text { Economic } \\
\text { growth }\end{array}$ & $\begin{array}{l}\text { SF support can lead to regional economic } \\
\text { growth and productivity growth, } \\
\text { but it depends on the effective distribution } \\
\text { of SF, that is linked to political behaviour. }\end{array}$ \\
\hline $\begin{array}{l}\text { Pellegrini and } \\
\text { Cerqua (2016) }\end{array}$ & $\begin{array}{l}1994-1999 \\
2000-2006 \\
2007-2013 \\
\end{array}$ & $\begin{array}{l}208 \text { NUTS-2 } \\
\text { regions (EU-15) }\end{array}$ & $\begin{array}{l}\text { Counterfactual } \\
\text { causal analysis and } \\
\text { RDD model } \\
\end{array}$ & $\begin{array}{l}\text { Economic } \\
\text { growth }\end{array}$ & $\begin{array}{l}\text { Positive effect on economic growth. } \\
\text { However, the effect depends } \\
\text { on the intensity of transfers. }\end{array}$ \\
\hline $\begin{array}{l}\text { Di Cataldo } \\
\text { (2017) }\end{array}$ & $\begin{array}{l}1994-1999 \\
2000-2006 \\
2007-2013\end{array}$ & $\begin{array}{l}\text { Two UK NUTS-2 } \\
\text { regions: } 134 \text { wards } \\
\text { of Cornwall and } \\
\text { the } 94 \text { wards } \\
\text { of South Yorkshire }\end{array}$ & $\begin{array}{l}\text { Synthetic control } \\
\text { method, difference- } \\
\text { in-differences (DID) } \\
\text { model }\end{array}$ & $\begin{array}{l}\text { Economic } \\
\text { growth and } \\
\text { unemployment }\end{array}$ & $\begin{array}{l}\text { Positive impact on reduction } \\
\text { of unemployment and on the promotion } \\
\text { of economic growth, but this effect depends } \\
\text { on funding intensity. }\end{array}$ \\
\hline
\end{tabular}




\begin{tabular}{|c|c|c|c|c|c|}
\hline $\begin{array}{l}\text { Gagliardi and } \\
\text { Percoco (2017) }\end{array}$ & 2000-2006 & $\begin{array}{l}\text { NUTS } 2 \text { regions } \\
\text { in EU15 and EU27 }\end{array}$ & $\begin{array}{l}\text { Regression } \\
\text { discontinuity design } \\
\text { (RDD) }\end{array}$ & $\begin{array}{l}\text { Economic } \\
\text { growth }\end{array}$ & $\begin{array}{l}\text { SF (expressed as ERDF plus ESF) and CF } \\
\text { taken together have positive effect on regional } \\
\text { growth. However, the effect depends } \\
\text { on the intensity of transfers. Moreover, } \\
\text { the effect for EU15 regions is lower } \\
\text { comparing with EU27. }\end{array}$ \\
\hline $\begin{array}{l}\text { Gagliardi and } \\
\text { Percoco (2017) }\end{array}$ & $2000-2006$ & $\begin{array}{l}257 \text { NUTS-2 and } \\
1233 \text { NUTS-3 } \\
\text { regions (EU-15, } \\
\text { EU-10) }\end{array}$ & $\begin{array}{l}\text { Ordinary Least } \\
\text { Squares (OLS) }\end{array}$ & $\begin{array}{l}\text { Economic } \\
\text { growth }\end{array}$ & $\begin{array}{l}\text { Positive effect on economic growth in lagging } \\
\text { regions. }\end{array}$ \\
\hline $\begin{array}{l}\text { Pontarollo } \\
(2017)\end{array}$ & 2000-2006 & $\begin{array}{l}202 \text { regions in } \\
\text { EU15 }\end{array}$ & $\begin{array}{l}\text { Semi-parametric } \\
\text { model }\end{array}$ & $\begin{array}{l}\text { Economic } \\
\text { growth, } \\
\text { productivity }\end{array}$ & $\begin{array}{l}\text { SF support effect depends on intervention } \\
\text { area. Expenditure on infrastructure had } \\
\text { positive impact on GVA per worker growth, } \\
\text { but had a weakly negative impact on per } \\
\text { capita GDP growth. Expenditure on human } \\
\text { capital had positive impact on per capita } \\
\text { GDP growth, but did not have significant } \\
\text { impact on GVA per worker growth. }\end{array}$ \\
\hline $\begin{array}{l}\text { Becker et al. } \\
(2018)\end{array}$ & $\begin{array}{l}\text { 1989-1993, } \\
1994-1999, \\
2000-2006, \\
2007-2013\end{array}$ & $\begin{array}{l}\text { NUTS-2 regions } \\
(187 \text { in } 1989-93 \text {, } \\
209 \text { in } 1994-99 \text {, } \\
253 \text { in } 2000-06 \text {, } \\
\text { and } 253 \text { in } 2007- \\
2013) \text { of EU-25 }\end{array}$ & $\begin{array}{l}\text { A fuzzy regression } \\
\text { discontinuity design } \\
\text { (RDD) }\end{array}$ & $\begin{array}{l}\text { Economic } \\
\text { growth }\end{array}$ & $\begin{array}{l}\text { Positive impact on economic growth } \\
\text { is though not very long-lived: the effects } \\
\text { of losing. } \\
\text { The effects on economic growth are weaker } \\
\text { during the Crisis than before. }\end{array}$ \\
\hline
\end{tabular}




\section{Appendix B}

Table B1. Assignment of regions into control and treatment groups and treatment intensity

\begin{tabular}{|c|c|c|c|c|c|}
\hline \multirow{3}{*}{ Fund / expenditure category } & \multicolumn{2}{|c|}{ Number of regions in } & \multirow{2}{*}{\multicolumn{3}{|c|}{$\begin{array}{c}\text { Funding intensity in treatment group over } \\
\text { policy intervention }(2000-2006) \text { period } \\
\text { Funding-to-GDP ratio }(\%)\end{array}$}} \\
\hline & \multirow{2}{*}{$\begin{array}{l}\text { Control } \\
\text { group }\end{array}$} & \multirow{2}{*}{$\begin{array}{l}\text { Treatment } \\
\text { group }\end{array}$} & & & \\
\hline & & & Min. & Average & Max. \\
\hline $\begin{array}{l}\text { All funds and all expenditure } \\
\text { categories }\end{array}$ & 244 & 1007 & 0.000157 & 0.50429 & 13.506 \\
\hline $\begin{array}{l}\text { 1. ERDF Objective } 1^{1,2} \\
\text { (all expenditure categories) }\end{array}$ & 837 & 414 & 0.0000165 & 0.8266 & 12.376 \\
\hline 1.1. Productive environment & 838 & 413 & 0.0000165 & 0.26806 & 2.7806 \\
\hline 1.2. Human resources & 1025 & 226 & 0.0000977 & 0.026831 & 0.40655 \\
\hline 1.3. Basic infrastructure & 843 & 408 & 0.00035604 & 0.53847 & 9.6107 \\
\hline 1.4. Miscellaneous & 884 & 367 & 0.000000269 & 0.015715 & 0.24877 \\
\hline $\begin{array}{l}\text { 2. ERDF Objective } 2^{1,3} \\
\text { (all expenditure categories) }\end{array}$ & 712 & 539 & 0.00007 & 0.078011 & 0.42617 \\
\hline 2.1. Productive environment & 714 & 537 & 0.0000143 & 0.050923 & 0.33620 \\
\hline 2.2. Human resources & 1051 & 200 & 0.000000321 & 0.0045651 & 0.033262 \\
\hline 2.3. Basic infrastructure & 772 & 479 & 0.0000189 & 0.026861 & 0.29975 \\
\hline 2.4. Miscellaneous & 803 & 448 & 0.00000803 & 0.0020597 & 0.042162 \\
\hline $\begin{array}{l}\text { 3. Cohesion fund } \\
\text { (all expenditure categories) }^{4}\end{array}$ & 1006 & 245 & 0.010217 & 0.44076 & 2.7355 \\
\hline \multicolumn{6}{|l|}{ 3.1. Productive environment } \\
\hline \multicolumn{6}{|l|}{ 3.2. Human resources } \\
\hline 3.3. Basic infrastructure & 1006 & 245 & 0.0072947 & 0.43704 & 2.7355 \\
\hline 3.4. Miscellaneous & 1131 & 120 & 0.0000962 & 0.0075874 & 0.13914 \\
\hline $\begin{array}{l}\text { 4. ERDF Urban } \\
\text { (all expenditure categories) }\end{array}$ & 1171 & 80 & 0.0000057 & 0.014437 & 0.12237 \\
\hline 4.1. Productive environment & 1185 & 66 & 0.00000499 & 0.0030871 & 0.025497 \\
\hline 4.2. Human resources & 1181 & 70 & 0.00000206 & 0.0024767 & 0.013445 \\
\hline 4.3. Basic infrastructure & 1175 & 76 & 0.00019551 & 0.0092983 & 0.10953 \\
\hline 4.4. Miscellaneous & 1178 & 73 & 0.00000364 & 0.00097517 & 0.0067776 \\
\hline $\begin{array}{l}\text { 5. ERDF INTERREG IIIA } \\
\text { (all expenditure categories) }\end{array}$ & 829 & 422 & 0.00075 & 0.03416 & 0.80787 \\
\hline 5.1. Productive environment & 829 & 422 & 0.00041239 & 0.012210 & 0.52220 \\
\hline 5.2. Human resources & 841 & 410 & 0.0000462 & 0.0023949 & 0.039610 \\
\hline 5.3. Basic infrastructure & 829 & 422 & 0.0000792 & 0.016747 & 0.29187 \\
\hline 5.4. Miscellaneous & 830 & 421 & 0.00000637 & 0.0028850 & 0.044615 \\
\hline $\begin{array}{l}\text { Productive environment } \\
\text { (all funds ERDF+CF) }\end{array}$ & 246 & 1005 & 0.00010066 & 0.14268 & 2.7806 \\
\hline $\begin{array}{l}\text { Human resources } \\
(\text { all funds ERDF+CF) }\end{array}$ & 540 & 711 & 0.00000044 & 0.011437 & 0.40655 \\
\hline $\begin{array}{l}\text { Basic infrastructure } \\
\text { (all funds ERDF+CF) }\end{array}$ & 285 & 966 & 0.0000286 & 0.35964 & 10.740 \\
\hline $\begin{array}{l}\text { Miscellaneous } \\
\text { (all funds ERDF+CF) }\end{array}$ & 326 & 925 & 0.000000269 & 0.0096069 & 0.25676 \\
\hline
\end{tabular}


1 ERDF during 2000-2006 was intended to help eliminate the main regional imbalances in the EU; therefore, it should have contributed reducing the gap between the regions of various development levels and the least-favoured regions and islands, including rural areas. ERDF should have contributed to social and economic regeneration of cities and urban neighbourhoods in crisis under the EU initiatives as well as to financing cross-border, transnational and interregional cooperation.

2 The aims of ERDF Objective 1 were to solve the problems in regions: to increase the level of investments, to decrease the unemployment rate, to decrease the lack of services for business and individuals and to improve poor basic infrastructure. Objective 1 was the main priority of the EU cohesion policy. The EU worked according to the Treaty of Rome to "promote harmonious development" and aims particularly to "narrow the gap between the development levels of the various regions". This is why $69.7 \%$ of the SF were planned to be allocated to Objective 1, including $4.3 \%$ for transitional support (i.e. a total of EUR 135.9 billion) and were allocated for the development of lagging regions (Council regulation: general provisions on the Structural Funds, 1999).

3 The aims of ERDF Objective 2 were to renew all areas, which have structural difficulties: industrial, rural and urban or are dependent on fisheries. Usually this situation is in regions whose development level is close to the EU average, such regions face with different types of socio-economic difficulties, which include: the complicated evolution of industrial or service sectors; the crisis situations in urban areas; the declining traditional activities in rural areas; the difficulties affecting fisheries activity. All these difficulties are often the source of high unemployment level. Objective 2 was to contribute to the social and economic conversion of regions with structural difficulties other than those eligible for Objective 1. Eligibility was depended on the ceiling of population and on the set of specific criteria to each region. It was planned that $11.5 \%$ of the SF will be allocated to Objective 2, including $1.4 \%$ for transitional support (i.e. a total of EUR 22.5 billion) (Council Regulation: general provisions on the Structural Funds, 1999).

4 Cohesion Fund. All the regions of Objective 1 of the EU Member States with a GDP of less than $90 \%$ of the EU average were supported by a special solidarity fund called Cohesion Fund (CF). It financed only the transport and environmental infrastructure projects, as well as technical support projects, including publicity and information campaigns. The CF financed projects only in some EU Member States in 2000-2004, it was namely Greece, Portugal, Ireland and Spain. The majority of their territory was covered by Objective 1. Only a few Objective 2 regions in Spain received assistance from the $\mathrm{CF}$, which co-finances environmental protection and transport projects. Since 2004, new EU member states have been included: the Czech Republic, Estonia, Cyprus, Latvia, Lithuania, Hungary, Malta, Poland, Slovenia and Slovakia. The CF was allocated to countries rather than to regions (Fratesi and Perucca, 2014). In the period between 2000 and 2006, total resources available for commitments for Ireland, Greece, Portugal and Spain were EUR 18 billion, and additional total resources available for commitments for Cyprus, the Czech Republic, Estonia, Hungary, Latvia, Lithuania, Malta, Poland, Slovakia and Slovenia in the period from the date of accession to 2006 were EUR 7.6 billion (Council regulation: establishing a Cohesion Fund, 2006).

5 Urban is the EU Initiative of the ERDF for sustainable development in the troubled urban districts for the period 2000-2006. The aim of Urban II was to promote the design and implementation of innovative development models for the social and economic regeneration of troubled urban areas. The programming documents during the period 2000-2006 of the regions eligible for priority Objectives 1 and 2 comprised integrated measures of social and economic development covering many urban areas. Through an integrated territorial approach, these measures should have contributed to the balanced development or conversion of the regions concerned. Furthermore, 
the measures financed under Objective 3 should also have strengthened social cohesion in the towns not covered by Objectives 1 and 2.

6 INTERREG III is an EU initiative which aim was to stimulate interregional cooperation in the EU in 2000-2006. INTERREG III was the part of the ERDF. This phase of the INTERREG initiative was designed to strengthen social and economic cohesion across the EU, by fostering the balanced development of Europe through: (i) cross-border cooperation for developing cross-border social and economic centres through common development strategies; (ii) transnational cooperation by involving national, regional and local authorities to promote better integration within the EU by creating the large groups of European regions; and (iii) interregional cooperation by creating networks for improving the effectiveness of regional development policies and instruments through large-scale information exchange and sharing of experience. Particular attention has been paid to the integration of remote regions, which share external borders with the candidate countries. INTERREG III was made from three priorities and had a total budget of EUR 4.875 billion.

The common objectives of all financial support expenditure categories: (i) productive environment financing of assisting SMEs, RDTI and large businesses, of development telecommunications and the information society; (ii) human resources - financing of education and training, social inclusion decisions; (iii) basic infrastructure - financing of transport infrastructure, energy and the environment, partly reflecting the CF's support to the latter, environment and environmental expenditure in enterprises, social infrastructure (generalised information from Ex post evaluation of cohesion policy programmes 2000-2006, 2009). 


\section{Appendix C}

Table C1. Description of the data for the research

\begin{tabular}{|c|c|c|c|}
\hline \multicolumn{2}{|l|}{ Variable } & \multirow{2}{*}{$\begin{array}{l}\text { Source of } \\
\text { the data }\end{array}$} & \multirow[b]{2}{*}{ Notes } \\
\hline Full name & $\begin{array}{l}\text { Short } \\
\text { name }\end{array}$ & & \\
\hline $\begin{array}{l}\text { Regional } \\
\text { per capita gross } \\
\text { domestic product } \\
\text { at constant prices }\end{array}$ & gdp & Eurostat & $\begin{array}{l}\text { The main source of the data is ESA } 2010 \text { (reg_ecologdp), subsection } \\
\text { for Gross domestic product (GDP) at current market prices by NUTS3 } \\
\text { regions (nama_10r_3gdp). To correct the changes at price levels over } \\
\text { time, we used Price index (implicit deflator), 2010=100, euro } \\
\text { (PDIO_EUR). To calculate per capita GDP we used Average annual } \\
\text { population to calculate regional GDP data (thousand persons) by NUTS } \\
3 \text { regions (nama_10r_3popgdp). Data for per capita GDP and population } \\
\text { in aforementioned Eurostat data sources is not available prior to } 2000 \text {. } \\
\text { Data for } 1995-1999 \text { on Gross domestic product (GDP) at current } \\
\text { market prices at NUTS level } 3 \text { and Average annual population was } \\
\text { retrieved from nama_r_e3gdp and demo_r_d3avg datasets that were } \\
\text { available on Eurostat previously and merged with currently available } \\
\text { dataset. }\end{array}$ \\
\hline $\begin{array}{l}\text { Working age } \\
\text { population }\end{array}$ & pop & Eurostat & $\begin{array}{l}\text { The main source of the data is Average annual population by age groups } \\
\text { (thousand persons) by NUTS } 3 \text { regions (nama_10r_3pop). Data } \\
\text { for population in aforementioned Eurostat data sources is not available } \\
\text { prior to } 2000 \text {. Data for } 1995-1999 \text { on Average annual population was } \\
\text { retrieved from demo_r_d3avg datasets that were available on Eurostat } \\
\text { previously and merged with currently available dataset. }\end{array}$ \\
\hline $\begin{array}{l}\text { Share of value } \\
\text { added created } \\
\text { in agriculture } \\
\text { sector }\end{array}$ & $\begin{array}{l}\text { Agricult } \\
\text { ure }\end{array}$ & \multirow{3}{*}{ Eurostat } & \multirow[t]{3}{*}{$\begin{array}{l}\text { The main source of the data is Gross value added at basic prices by } \\
\text { NUTS } 3 \text { regions (nama_10r_3gva). Data in aforementioned Eurostat } \\
\text { data sources is not available prior to 2000. Data for } 1995 \text { - } 1999 \\
\text { on Gross value added at basic prices at NUTS level 3was retrieved } \\
\text { from nama_r_e3vabp95. }\end{array}$} \\
\hline $\begin{array}{l}\text { Share of value } \\
\text { added created } \\
\text { in industry sector }\end{array}$ & Industry & & \\
\hline $\begin{array}{l}\text { Share of value } \\
\text { added created } \\
\text { in service sector }\end{array}$ & Service & & \\
\hline $\begin{array}{l}\text { Dummy variable } \\
\text { for capital region }\end{array}$ & $\begin{array}{l}\text { Capital } \\
\text { dummy }\end{array}$ & \multirow{5}{*}{ Eurostat } & \multirow{5}{*}{$\begin{array}{l}\text { Information for NUTS } 3 \text { typologies and local information were collected } \\
\text { from Regional typologies and local information corresponding to NUTS } \\
3 \text { (available at http://ec.europa.eu/eurostat/ } \\
\text { documents/345175/6807882/Ttypologies+and } \\
\text { +local+information+corresponding+to+NUTS3.xls) }\end{array}$} \\
\hline $\begin{array}{l}\text { Dummy variable } \\
\text { for costal region }\end{array}$ & $\begin{array}{l}\text { Costal } \\
\text { dummy }\end{array}$ & & \\
\hline $\begin{array}{l}\text { Dummy variable } \\
\text { for region with } \\
\text { a port }\end{array}$ & $\begin{array}{c}\text { Port } \\
\text { dummy }\end{array}$ & & \\
\hline $\begin{array}{l}\text { Dummy variable } \\
\text { for urban region }\end{array}$ & $\begin{array}{l}\text { Urban } \\
\text { dummy }\end{array}$ & & \\
\hline $\begin{array}{l}\text { Dummy variable } \\
\text { for rural region }\end{array}$ & $\begin{array}{c}\text { Rural } \\
\text { dummy }\end{array}$ & & \\
\hline Treatment dummy & $\mathrm{dT}$ & & \multirow[b]{2}{*}{$\begin{array}{l}\text { Concerning ERDF and CF, DG REGIO has carried out some analyses } \\
\text { reflecting on allocations and expenditures at NUTS3 levels across time. } \\
\text { The data resulting from these analyses is published on the } \\
\text { "Data for research" page of EC website } \\
\text { (http://ec.europa.eu/regional_policy/en/policy/evaluations/data-for- } \\
\text { research/). In particular, for the period 2000-2006, you can refer } \\
\text { to the following link:http://ec.europa.eu/regional_policy/sources } \\
\text { /docgener/evaluation/pdf/expost2006/expenditure_final_annex1.xls } \\
\text { (Breakdown by NUTS3 level regions and sectors). Please note that all } \\
\text { data is the result of estimation procedures. The details of the procedure } \\
\text { and its limitations are described in the Report available at: } \\
\text { http://ec.europa.eu/regional_policy/sour } \\
\text { ces/docgener/evaluation/pdf/expost2006/expenditure_final.pdf }\end{array}$} \\
\hline $\begin{array}{l}\text { Treatment } \\
\text { intensity }\end{array}$ & Tint & $\begin{array}{c}\text { European } \\
\text { Commission }\end{array}$ & \\
\hline
\end{tabular}


Table C2. Growth averages of per capita GDP and working age population

\begin{tabular}{|l|c|c|c|c|c|c|}
\hline \multirow{2}{*}{ Variable } & \multirow{2}{*}{ Group $^{(\mathbf{1})}$} & $\begin{array}{c}\text { Pre-policy } \\
\text { period }\end{array}$ & \multicolumn{4}{|c|}{ Post-policy period } \\
\cline { 3 - 7 } & $\mathbf{1 9 9 5 - 1 9 9 9}$ & $\mathbf{2 0 0 7 - 2 0 1 1}$ & $\mathbf{2 0 0 7 - 2 0 1 2}$ & $\mathbf{2 0 0 7 - 2 0 1 3}$ & $\mathbf{2 0 0 7 - 2 0 1 4}$ \\
\hline $\begin{array}{l}\text { Average year-to- } \\
\text { year growth rate } \\
\text { of per capita } \\
\begin{array}{l}\text { GDP at constant } \\
\text { prices, \% }\end{array}\end{array}$ & Control & 2.31 & 0.06 & -0.01 & 1.16 & 0.92 \\
\cline { 2 - 7 } & Treatment & 2.56 & -0.32 & -0.51 & 0.70 & 0.54 \\
\hline $\begin{array}{l}\text { Average year-to- } \\
\text { year growth rate } \\
\text { of working age } \\
\text { population, \% }\end{array}$ & Control & 0.506 & 0.233 & 0.272 & 0.328 & 0.390 \\
\cline { 2 - 7 } & Treatment & 0.123 & 0.148 & 0.106 & 0.078 & 0.073 \\
\hline
\end{tabular}

(1) Here control group consists of 244 NUTS 3 regions that did not received any support from ERDF and CF over 2000-2006 programming period. Treatment group consists of 1007 NUTS 3 regions that received funding from ERDF and/or CF during the same period. Analysing separate funds or expenditure categories distribution of regions between treatment and control group varies, but total number of regions remains the same.

Table C3. Averages of quantitative control variables in control and treatment groups

\begin{tabular}{|c|c|c|c|}
\hline Variable & Group $^{(1)}$ & Average in 1995 & Average in 2007 \\
\hline \multirow{2}{*}{$\begin{array}{l}\text { Per capita GDP at constant } \\
\text { prices, EUR }\end{array}$} & Control & 24907 & 33281 \\
\hline & Treatment & 18982 & 24946 \\
\hline \multirow{2}{*}{$\begin{array}{l}\text { Share of value added } \\
\text { in Agriculture sector, \% }\end{array}$} & Control & 2.73 & 1.44 \\
\hline & Treatment & 5.48 & 2.99 \\
\hline \multirow{2}{*}{$\begin{array}{l}\text { Share of value added } \\
\text { in Industry sector, \% }\end{array}$} & Control & 25.37 & 23.64 \\
\hline & Treatment & 24.08 & 22.53 \\
\hline \multirow{2}{*}{$\begin{array}{l}\text { Share of value added } \\
\text { in Service sector, \% }\end{array}$} & Control & 66.42 & 69.35 \\
\hline & Treatment & 63.49 & 67.34 \\
\hline \multirow{2}{*}{$\begin{array}{l}\text { Share of value added } \\
\text { in Construction } \text { sector }^{(2)}, \%\end{array}$} & Control & 5.48 & 5.57 \\
\hline & Treatment & 6.95 & 7.14 \\
\hline
\end{tabular}

(1) Here control group consists of 244 NUTS 3 regions that did not received any support from ERDF and CF over 2000-2006 programming period. Treatment group consists of 1007 NUTS 3 regions that received funding from ERDF and/or CF during the same period. Analysing separate funds or expenditure categories distribution of regions between treatment and control group varies, but total number of regions remain the same.

(2) Construction sector is omitted from the estimations due to exact collinearity witch would occur if all sectors making up $100 \%$ of Value Added are included.

Table C4. Distribution of regions in the control and treatment groups according to location specific factors and urban-rural typology

\begin{tabular}{|c|c|c|c|c|c|c|}
\hline \multirow[b]{2}{*}{ Group $^{(1)}$} & \multirow[b]{2}{*}{$\begin{array}{c}\text { Capital region, } \\
\%\end{array}$} & \multirow[b]{2}{*}{$\begin{array}{c}\text { Coastal region, } \\
\%\end{array}$} & \multirow[b]{2}{*}{$\begin{array}{c}\text { Port region, } \\
\%\end{array}$} & \multicolumn{3}{|c|}{ Urban-rural typology } \\
\hline & & & & $\begin{array}{c}\text { Rural } \\
\text { region, \% }\end{array}$ & $\begin{array}{c}\text { Intermediate } \\
\text { region }^{(2)}, \%\end{array}$ & $\begin{array}{c}\text { Urban } \\
\text { region, \% }\end{array}$ \\
\hline Control & 7 & 26 & 28 & 15 & 37 & 48 \\
\hline Treatment & 4 & 37 & 38 & 39 & 38 & 23 \\
\hline
\end{tabular}

(1) Here control group consists of 244 NUTS 3 regions that did not received any support from ERDF and CF over 2000-2006 programming period. Treatment group consists of 1007 NUTS 3 regions that received funding from ERDF and/or CF during the same period. Analysing separate funds or expenditure categories distribution of regions between treatment and control group varies, but total number of regions remain the same.

${ }^{(2)}$ Intermediate region is omitted category and set as a benchmark type of the region. 
Appendix D

Table D1. Estimations for 2007-2011 post-policy period

\begin{tabular}{|c|c|c|c|c|c|c|c|c|c|c|c|c|}
\hline & \multirow{2}{*}{\multicolumn{2}{|c|}{$\begin{array}{l}\text { All funds and all } \\
\text { expenditure categories }\end{array}$}} & \multicolumn{10}{|c|}{ 1. ERDF Objective 1} \\
\hline & & & \multicolumn{2}{|c|}{$\begin{array}{l}\text { All expenditure } \\
\text { categories }\end{array}$} & \multicolumn{2}{|c|}{$\begin{array}{l}\text { 1.1. Productive } \\
\text { environment }\end{array}$} & \multicolumn{2}{|c|}{ 1.2. Human resources } & \multicolumn{2}{|c|}{$\begin{array}{c}\text { 1.3. Basic } \\
\text { infrastructure }\end{array}$} & \multicolumn{2}{|c|}{ 1.4. Miscellaneous } \\
\hline & Td & Tint & Td & Tint & Td & Tint & Td & Tint & Td & Tint & Td & Tint \\
\hline \multirow{2}{*}{ const } & 0.0097 & 0.0060 & -0.0131 & 0.0029 & -0.0124 & -0.0054 & 0.0007 & 0.0113 & -0.0116 & 0.0090 & 0.0008 & 0.0243 \\
\hline & $(0.0175)$ & $(0.0171)$ & $(0.0180)$ & $(0.0171)$ & $(0.0180)$ & $(0.0175)$ & $(0.0175)$ & $(0.0171)$ & $(0.0180)$ & $(0.0170)$ & $(0.0175)$ & $(0.0168)$ \\
\hline \multirow{2}{*}{ Initial per capita GDP } & $-0.0119^{* *}$ & $-0.0113^{* *}$ & $-0.0107 * *$ & $-0.0116^{* *}$ & $-0.0107^{* *}$ & $-0.0115^{* *}$ & $-0.0122 * *$ & $-0.0118^{* *}$ & $-0.0108^{* *}$ & $-0.0117 * *$ & $-0.0112 * *$ & $-0.0121 * *$ \\
\hline & $(0.0016)$ & $(0.0015)$ & $(0.0016)$ & $(0.0015)$ & $(0.0016)$ & $(0.0016)$ & $(0.0015)$ & $(0.0016)$ & $(0.0016)$ & $(0.0015)$ & $(0.0016)$ & $(0.0015)$ \\
\hline \multirow{2}{*}{ Population growth } & $0.3667 * *$ & $0.3803^{* *}$ & $0.3388 * *$ & $0.3768 * *$ & $0.3417 * *$ & $0.3540 * *$ & $0.3806 * *$ & $0.3815^{* *}$ & $0.3428 * *$ & $0.3920 * *$ & $0.3486 * *$ & $0.3710 * *$ \\
\hline & $(0.0648)$ & $(0.0633)$ & $(0.0646)$ & $(0.0632)$ & $(0.0646)$ & $(0.0643)$ & $(0.0640)$ & $(0.0635)$ & $(0.0648)$ & $(0.0630)$ & $(0.0641)$ & $(0.0626)$ \\
\hline \multirow{2}{*}{ Agriculture } & $-0.0016^{* *}$ & $-0.0014 * *$ & $-0.0015 * *$ & $-0.0014 * *$ & $-0.0015^{* *}$ & $-0.0016^{* *}$ & $-0.0015^{* *}$ & $-0.0016^{* *}$ & $-0.0015^{* *}$ & $-0.0014 * *$ & $-0.0014 * *$ & $-0.0013 * *$ \\
\hline & $(0.0002)$ & $(0.0002)$ & $(0.0002)$ & $(0.0002)$ & $(0.0002)$ & $(0.0002)$ & $(0.0002)$ & $(0.0002)$ & $(0.0002)$ & $(0.0002)$ & $(0.0002)$ & $(0.0002)$ \\
\hline \multirow{2}{*}{ Industry } & $0.0015^{* *}$ & $0.0015^{* *}$ & $0.0017^{* *}$ & $0.0016^{* * *}$ & $0.0017 * *$ & $0.0017 * *$ & $0.0017 * *$ & $0.0015 * *$ & $0.0017 * *$ & $0.0015 * *$ & $0.0016^{* *}$ & $0.0014 * *$ \\
\hline & $(0.0001)$ & $(0.0001)$ & $(0.0001)$ & $(0.0002)$ & $(0.0001)$ & $(0.0001)$ & $(0.0001)$ & $(0.0001)$ & $(0.0001)$ & $(0.0001)$ & $(0.0001)$ & $(0.0001)$ \\
\hline \multirow{2}{*}{ Service } & $0.0014 * *$ & $0.0014 * *$ & $0.0015^{* *}$ & $0.0014 * *$ & $0.0015^{* *}$ & $0.0015^{* *}$ & $0.0015 * *$ & $0.0014^{* *}$ & $0.0015^{* *}$ & $0.0014 * *$ & $0.0014 * *$ & $0.0013 * *$ \\
\hline & $(0.0001)$ & $(0.0002)$ & $(0.0001)$ & $(0.0002)$ & $(0.0001)$ & $(0.0001)$ & $(0.0001)$ & $(0.0001)$ & $(0.0001)$ & $(0.0001)$ & $(0.0001)$ & $(0.0001)$ \\
\hline \multirow{2}{*}{ Capital dummy } & $0.01648^{* * *}$ & $0.0170^{* *}$ & $0.0162 * *$ & $0.0170^{* *}$ & $0.0162 * *$ & $0.0168 * *$ & $0.0165 * *$ & $0.0169^{* *}$ & $0.0163^{* *}$ & $0.0169 * *$ & $0.0161 * *$ & $0.0165^{* *}$ \\
\hline & $(0.0022)$ & $(0.0022)$ & $(0.0022)$ & $(0.0022)$ & $(0.0022)$ & $(0.0022)$ & $(0.0022)$ & $(0.0022)$ & $(0.0022)$ & $(0.0022)$ & $(0.0022)$ & $(0.0022)$ \\
\hline \multirow{2}{*}{ Costal dummy } & 0.0003 & 0.0004 & 0.0003 & 0.0004 & 0.0003 & 0.0003 & 0.0004 & 0.0003 & 0.0003 & 0.0004 & 0.0003 & 0.0002 \\
\hline & $(0.0013)$ & $(0.0013)$ & $(0.0013)$ & $(0.0013)$ & $(0.0013)$ & $(0.0013)$ & $(0.0013)$ & $(0.0013)$ & $(0.0013)$ & $(0.0013)$ & $(0.0013)$ & $(0.0013)$ \\
\hline \multirow{2}{*}{ Port dummy } & -0.0005 & -0.0004 & -0.0006 & -0.0004 & -0.0006 & -0.0004 & -0.0005 & -0.0005 & -0.0006 & -0.0004 & -0.0006 & -0.0004 \\
\hline & $(0.0012)$ & $(0.0012)$ & $(0.0012)$ & $(0.0012)$ & $(0.0012)$ & $(0.0012)$ & $(0.0012)$ & $(0.0012)$ & $(0.0012)$ & $(0.001)$ & $(0.0012)$ & $(0.0012)$ \\
\hline \multirow{2}{*}{ Urban dummy } & -0.0004 & -0.0009 & -0.0011 & -0.0009 & -0.0011 & -0.0007 & -0.0012 & -0.0007 & -0.0011 & -0.0009 & -0.0011 & -0.0010 \\
\hline & $(0.0012)$ & $(0.0011)$ & $(0.0011)$ & $(0.0011)$ & $(0.0011)$ & $(0.0011)$ & $(0.0011)$ & $(0.0011)$ & $(0.0011)$ & $(0.0011)$ & $(0.0011)$ & $(0.0011)$ \\
\hline \multirow{2}{*}{ Rural dummy } & -0.0001 & 0.0006 & 0.0007 & 0.0006 & 0.0007 & 0.0004 & 0.0006 & 0.0002 & 0.0007 & 0.0005 & 0.0006 & 0.0004 \\
\hline & $(0.0011)$ & $(0.0011)$ & $(0.0011)$ & $(0.0011)$ & $(0.0011)$ & $(0.0011)$ & $(0.0011)$ & $(0.0011)$ & $(0.0011)$ & $(0.0011)$ & $(0.0011)$ & $(0.0010)$ \\
\hline \multirow{2}{*}{$\begin{array}{l}\text { Post-policy period } \\
\text { dummy }(t 2)\end{array}$} & $-0.0194 * *$ & $-0.0212 * *$ & $-0.0196 * *$ & $-0.0213 * *$ & $-0.0197 * *$ & $-0.0217 * *$ & $-0.0201 * *$ & $-0.0224 * *$ & $-0.0198 * *$ & $-0.0216^{* *}$ & $-0.0199 * *$ & $-0.0216^{* *}$ \\
\hline & $(0.0019)$ & $(0.00097)$ & $(0.0010)$ & $(0.0010)$ & $(0.0010)$ & $(0.0010)$ & $(0.0010)$ & $(0.0009)$ & $(0.0010)$ & $(0.0009)$ & $(0.0010)$ & $(0.0009)$ \\
\hline \multirow{2}{*}{$\begin{array}{l}\text { Treatment group } \\
\text { dummy }(d T)\end{array}$} & $0.0041 * *$ & & $0.0108 * *$ & & $0.0106 * *$ & & $0.0114 * *$ & & $0.0104 * *$ & & $0.0095 * *$ & \\
\hline & $(0.0015)$ & & $(0.0015)$ & & $(0.0015)$ & & $(0.0018)$ & & $(0.0015)$ & & $(0.0015)$ & \\
\hline \multirow{2}{*}{$\begin{array}{l}\text { Difference-in-difference } \\
\text { estimator }(t 2 \times d T)\end{array}$} & $-0.0048 * *$ & & $-0.0135^{* *}$ & & $-0.0134 * *$ & & $-0.0194 * *$ & & $-0.0132 * *$ & & $-0.0138 * *$ & \\
\hline & $(0.0020)$ & & $(0.0017)$ & & $(0.0017)$ & & $(0.0021)$ & & $(0.0017)$ & & $(0.0018)$ & \\
\hline \multirow{2}{*}{$\begin{array}{l}\text { Treatment intensity } \\
\text { (Tint) }\end{array}$} & & $0.0059^{* *}$ & & $0.0077 * *$ & & $0.0213^{* *}$ & & $0.1560^{* * *}$ & & $0.0100^{* * *}$ & & $0.2745^{* *}$ \\
\hline & & $(0.0008)$ & & $(0.0009)$ & & $(0.0032)$ & & $(0.0300)$ & & $(0.0013)$ & & $(0.0367)$ \\
\hline \multirow{2}{*}{$\begin{array}{l}\text { Post-policy period } \\
\text { dummy } * \text { Treatment } \\
\text { intensity }(t 2 \times \text { Tint })\end{array}$} & & $-0.0067 * *$ & & $-0.0091 * *$ & & $-0.0220 * *$ & & $-0.1961^{* *}$ & & $-0.0127 * *$ & & $-0.4482 * *$ \\
\hline & & $(0.0009)$ & & $(0.0011)$ & & $(0.0038)$ & & $(0.0404)$ & & $(0.0015)$ & & $(0.0448)$ \\
\hline $\mathrm{n}$ & 2502 & 2502 & 2502 & 2502 & 2502 & 2502 & 2502 & 2502 & 2502 & 2502 & 2502 & 2502 \\
\hline $\mathbf{R}^{2}$ & 0.4790 & 0.4920 & 0.4919 & 0.4946 & 0.4916 & 0.4873 & 0.4958 & 0.4837 & 0.4910 & 0.4945 & 0.4908 & 0.4982 \\
\hline
\end{tabular}

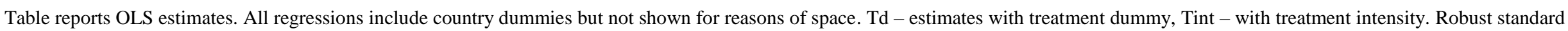
errors are reported in parentheses. * indicates significance at the 10 percent level, ** indicates significance at the 5 percent level 
Table D1. (continued)

\begin{tabular}{|c|c|c|c|c|c|c|c|c|c|c|c|c|}
\hline & \multirow{2}{*}{\multicolumn{2}{|c|}{$\begin{array}{c}\text { Productive } \\
\text { environment (all funds } \\
\text { ERDF+CF) }\end{array}$}} & \multicolumn{10}{|c|}{ 2. ERDF Objective 2} \\
\hline & & & \multicolumn{2}{|c|}{$\begin{array}{c}\text { All expenditure } \\
\text { categories }\end{array}$} & \multicolumn{2}{|c|}{$\begin{array}{l}\text { 2.1. Productive } \\
\text { environment }\end{array}$} & \multicolumn{2}{|c|}{ 2.2. Human resources } & \multicolumn{2}{|c|}{$\begin{array}{c}\text { 2.3. Basic } \\
\text { infrastructure }\end{array}$} & \multicolumn{2}{|c|}{ 2.4. Miscellaneous } \\
\hline & Td & Tint & Td & Tint & Td & Tint & Td & Tint & Td & Tint & Td & Tint \\
\hline const & $(0.0175)$ & $(0.0176)$ & $(0.0171)$ & $(0.0171)$ & $(0.0171)$ & $(0.0171)$ & $(0.0171)$ & $(0.0171)$ & $(0.0171)$ & $(0.0171)$ & $(0.0172)$ & $(0.0171)$ \\
\hline \multirow{2}{*}{ Initial per capita GDP } & $-0.0119 * *$ & $-0.0116^{* *}$ & $-0.0116^{* *}$ & $-0.0119 * *$ & $-0.0116^{* *}$ & $-0.0121 * *$ & $-0.0119 * *$ & $-0.0119 * *$ & $-0.0117 * *$ & $-0.0118^{* *}$ & $-0.0118^{* *}$ & $-0.0120 * *$ \\
\hline & $(0.0016)$ & $(0.0016)$ & $(0.0016)$ & $(0.0016)$ & $(0.0016)$ & $(0.0016)$ & $(0.0016)$ & $(0.0016)$ & $(0.0016)$ & $(0.0016)$ & $(0.0016)$ & $(0.0016)$ \\
\hline Population growth & $(0.0648)$ & $(0.0649)$ & $(0.0637)$ & $(0.0640)$ & $(0.0637)$ & $(0.0639)$ & $(0.0639)$ & $(0.0638)$ & $(0.0638)$ & $(0.0641)$ & $(0.0641)$ & $(0.064)$ \\
\hline \multirow{2}{*}{ Agriculture } & $-0.0016^{* *}$ & $-0.0016^{* *}$ & $-0.0016^{* *}$ & $-0.0016^{* *}$ & $-0.0016^{* *}$ & $-0.0016^{* *}$ & $-0.0016^{* *}$ & $-0.0016^{* *}$ & $-0.0016 * *$ & $-0.0016^{* *}$ & $-0.0016^{* *}$ & $-0.0016^{* *}$ \\
\hline & $(0.0002)$ & $(0.0002)$ & $(0.0002)$ & $(0.0002)$ & $(0.0002)$ & $(0.0002)$ & $(0.0002)$ & $(0.0002)$ & $(0.0002)$ & $(0.0002)$ & $(0.0002)$ & $(0.0002)$ \\
\hline \multirow{2}{*}{ Industry } & $0.0015^{* *}$ & $0.0016^{* *}$ & $0.0015^{* *}$ & $0.0015^{* *}$ & $0.0015^{* *}$ & $0.0015^{* *}$ & $0.0015^{* *}$ & $0.0015^{* *}$ & $0.0015^{* *}$ & $0.0015^{* *}$ & $0.0015^{* *}$ & $0.0015 * *$ \\
\hline & $(0.0001)$ & $(0.0001)$ & $(0.0001)$ & $(0.0001)$ & $(0.0001)$ & $(0.0001)$ & $(0.0001)$ & $(0.0001)$ & $(0.0001)$ & $(0.0001)$ & $(0.0001)$ & $(0.0001)$ \\
\hline \multirow{2}{*}{ Service } & $0.0014 * *$ & $0.0015^{* *}$ & $0.0014^{* *}$ & $0.0014 * *$ & $0.0014 * *$ & $0.0014 * *$ & $0.0013^{* *}$ & $0.0013^{* *}$ & $0.0014 * *$ & $0.0014 * *$ & $0.0014 * *$ & $0.0014 * *$ \\
\hline & $(0.0001)$ & $(0.0001)$ & $(0.0001)$ & $(0.0001)$ & $(0.0001)$ & $(0.0001)$ & $(0.0001)$ & $(0.0001)$ & $(0.0001)$ & $(0.0001)$ & $(0.0001)$ & $(0.0001)$ \\
\hline \multirow{2}{*}{ Capital dummy } & $0.0165 * *$ & $0.0168 * *$ & $0.0165 * *$ & $0.0164 * *$ & $0.0165 * *$ & $0.0164 * *$ & $0.0167 * *$ & $0.0164 * *$ & $0.0165 * *$ & $0.0165 * *$ & $0.0165 * *$ & $0.0163 * *$ \\
\hline & $(0.0022)$ & $(0.0022)$ & $(0.0022)$ & $(0.0022)$ & $(0.0022)$ & $(0.0022)$ & $(0.0022)$ & $(0.0022)$ & $(0.0022)$ & $(0.0022)$ & $(0.0022)$ & $(0.0022)$ \\
\hline \multirow{2}{*}{ Costal dummy } & 0.0003 & 0.0003 & 0.0003 & 0.0005 & 0.0003 & 0.0005 & 0.0004 & 0.0005 & 0.0003 & 0.0003 & 0.0002 & 0.0001 \\
\hline & $(0.0013)$ & $(0.0013)$ & $(0.0013)$ & $(0.0013)$ & $(0.0013)$ & $(0.0013)$ & $(0.0013)$ & $(0.0013)$ & $(0.0013)$ & $(0.0013)$ & $(0.0013)$ & $(0.0013)$ \\
\hline \multirow{2}{*}{ Port dummy } & -0.0005 & -0.0004 & -0.0004 & -0.0004 & -0.0004 & -0.0004 & -0.0003 & -0.0005 & -0.0004 & -0.0004 & -0.0003 & -0.0003 \\
\hline & $(0.0012)$ & $(0.0012)$ & $(0.0012)$ & $(0.0012)$ & $(0.0012)$ & $(0.0012)$ & $(0.0012)$ & $(0.0012)$ & $(0.0012)$ & $(0.0012)$ & $(0.0012)$ & $(0.0012)$ \\
\hline \multirow{2}{*}{ Urban dummy } & -0.0005 & -0.0006 & -0.0009 & -0.0009 & -0.0009 & -0.0009 & -0.0005 & -0.0006 & -0.0008 & -0.0007 & -0.0007 & -0.0004 \\
\hline & $(0.0012)$ & $(0.0012)$ & $(0.0012)$ & $(0.0012)$ & $(0.0012)$ & $(0.0012)$ & $(0.0012)$ & $(0.0012)$ & $(0.0012)$ & $(0.0012)$ & $(0.0012)$ & $(0.0012)$ \\
\hline \multirow{2}{*}{ Rural dummy } & -0.0001 & 0.0002 & 0.00013 & 0.0003 & 0.00012 & 0.0003 & -0.0002 & -0.0002 & $-3,327 \mathrm{e}-05$ & $-2,950 \mathrm{e}-05$ & $-7,439 \mathrm{e}-06$ & $6,092 \mathrm{e}^{-05}$ \\
\hline & $(0.0011)$ & $(0.0011)$ & $(0.0011)$ & $(0.0011)$ & $(0.0011)$ & $(0.0011)$ & $(0.0011)$ & $(0.0011)$ & $(0.0011)$ & $(0.0011)$ & $(0.0011)$ & $(0.0011)$ \\
\hline \multirow{2}{*}{$\begin{array}{l}\text { Post-policy period } \\
\text { dummy }(t 2)\end{array}$} & $-0.0192 * *$ & $-0.0214^{* *}$ & $-0.0261 * *$ & $-0.0246^{* *}$ & $-0.0260 * *$ & $-0.0247 * *$ & $-0.0223^{* *}$ & $-0.0227 * *$ & $-0.0253^{* *}$ & $-0.0237 * *$ & $-0.0240 * *$ & $-0.0236 * *$ \\
\hline & $(0.0018)$ & $(0.0010)$ & $(0.0012)$ & $(0.0010)$ & $(0.0012)$ & $(0.0010)$ & $(0.0010)$ & $(0.0009)$ & $(0.0012)$ & $(0.0010)$ & $(0.0011)$ & $(0.0010)$ \\
\hline \multirow{2}{*}{$\begin{array}{l}\text { Treatment group } \\
\text { dummy }(d T)\end{array}$} & $0.0043 * *$ & & $-0.0044 * *$ & & $-0.0042 * *$ & & 0.00042 & & $-0.0028 * *$ & & $-0.0032 * *$ & \\
\hline & $(0.0015)$ & & $(0.0013)$ & & $(0.0013)$ & & $(0.0017)$ & & $(0.0013)$ & & $(0.0013)$ & \\
\hline \multirow{2}{*}{$\begin{array}{l}\text { Treatment intensity } \\
\text { (Tint) }\end{array}$} & & $0.0178 * *$ & & $-0.0406^{* *}$ & & $-0.0642 * *$ & & 0.0392 & & $-0.0487 * *$ & & $-0.6755^{* *}$ \\
\hline & & $(0.0033)$ & & $(0.0099)$ & & $(0.0141)$ & & $(0.2085)$ & & $(0.0246)$ & & $(0.2362)$ \\
\hline \multirow{2}{*}{$\begin{array}{l}\text { Post-policy period } \\
\text { dummy } * \text { Treatment } \\
\text { intensity }(t 2 \times \text { Tint })\end{array}$} & & $-0.0190^{* *}$ & & $0.0379 * *$ & & $0.0646^{* *}$ & & $-0.7072 * *$ & & 0.0443 & & 0.4839 \\
\hline & & $(0.0039)$ & & $(0.0133)$ & & $(0.0190)$ & & $(0.2692)$ & & $(0.0331)$ & & $(0.3244)$ \\
\hline $\mathbf{n}$ & 2502 & 2502 & 2502 & 2502 & 2502 & 2502 & 2502 & 2502 & 2502 & 2502 & 2502 & 2502 \\
\hline $\mathbf{R}^{2}$ & 0.4792 & 0.4844 & 0.4808 & 0.4809 & 0.4806 & 0.4818 & 0.4793 & 0.4797 & 0.4793 & 0.4782 & 0.4788 & 0.4792 \\
\hline
\end{tabular}

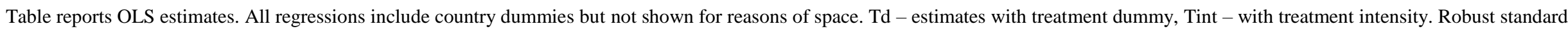
errors are reported in parentheses. * indicates significance at the 10 percent level, $* *$ indicates significance at the 5 percent level 
Table D1. (continued)

\begin{tabular}{|c|c|c|c|c|c|c|c|c|c|c|c|c|}
\hline & \multirow{2}{*}{\multicolumn{2}{|c|}{$\begin{array}{l}\text { Human resources (all } \\
\text { funds ERDF+CF) }\end{array}$}} & \multirow{2}{*}{\multicolumn{2}{|c|}{$\begin{array}{l}\text { Basic infrastructure (all } \\
\text { funds ERDF+CF) }\end{array}$}} & \multirow{2}{*}{\multicolumn{2}{|c|}{$\begin{array}{l}\text { Miscellaneous (all funds } \\
\text { ERDF+CF) }\end{array}$}} & \multicolumn{6}{|c|}{ 3. Cohesion fund } \\
\hline & & & & & & & \multicolumn{2}{|c|}{ All expenditure } & \multicolumn{2}{|c|}{ 3.3. Basic } & \multicolumn{2}{|c|}{ 3.4. Miscellaneous } \\
\hline & Td & Tint & Td & Tint & Td & Tint & Td & Tint & Td & Tint & Td & Tint \\
\hline \multirow[t]{2}{*}{ const } & 0.0146 & 0.0116 & 0.0084 & 0.0111 & 0.0178 & 0.0239 & 0.0250 & 0.0165 & 0.0250 & 0.0166 & 0.0180 & 0.0158 \\
\hline & $(0.0173)$ & $(0.0172)$ & $(0.0175)$ & $(0.0170)$ & $(0.0172)$ & $(0.0169)$ & $(0.0170)$ & $(0.0171)$ & $(0.0170)$ & $(0.0171)$ & $(0.0171)$ & $(0.0171)$ \\
\hline \multirow[t]{2}{*}{ Initial per capita GDP } & $-0.0121 * *$ & $-0.0117 * *$ & $-0.0118 * *$ & $-0.0113 * *$ & $-0.0122 * *$ & $-0.0119 * *$ & $-0.0114 * *$ & $-0.0115 * *$ & $-0.0114 * *$ & $-0.0115^{* *}$ & $-0.0124 * *$ & $-0.0121 * *$ \\
\hline & $(0.0016)$ & $(0.0016)$ & $(0.0016)$ & $(0.0015)$ & $(0.0016)$ & $(0.0015)$ & $(0.0016)$ & $(0.0016)$ & $(0.0016)$ & $(0.0016)$ & $(0.0016)$ & $(0.0016)$ \\
\hline \multirow[t]{2}{*}{ Population growth } & $0.3750 * *$ & $0.3755^{* *}$ & $0.3663 * *$ & $0.3949 * *$ & $0.3643 * *$ & $0.3827 * *$ & $0.3805 * *$ & $0.4038 * *$ & $0.3805 * *$ & $0.4037 * *$ & $0.3968 * *$ & $0.3871 * *$ \\
\hline & $(0.0643)$ & $(0.0635)$ & $(0.0646)$ & $(0.0631)$ & $(0.0649)$ & $(0.0630)$ & $(0.0632)$ & $(0.0636)$ & $(0.0632)$ & $(0.0636)$ & $(0.0636)$ & $(0.0639)$ \\
\hline \multirow[t]{2}{*}{ Agriculture } & $-0.0016^{* *}$ & $-0.0016^{* *}$ & $-0.0016^{* *}$ & $-0.0013^{* *}$ & $-0.0015^{* *}$ & $-0.0013 * *$ & $-0.0012 * *$ & $-0.0015 * *$ & $-0.0012 * *$ & $-0.0015^{* *}$ & $-0.0017 * *$ & $-0.0017 * *$ \\
\hline & $(0.0002)$ & $(0.0002)$ & $(0.0002)$ & $(0.0002)$ & $(0.0002)$ & $(0.0002)$ & $(0.0002)$ & $(0.0002)$ & $(0.0002)$ & $(0.0002)$ & $(0.0002)$ & $(0.0002)$ \\
\hline \multirow[t]{2}{*}{ Industry } & $0.0015^{* *}$ & $0.0015^{* *}$ & $0.0015^{* *}$ & $0.0015^{* *}$ & $0.0015^{* *}$ & $0.0014 * *$ & $0.0013^{* *}$ & $0.0014^{* *}$ & $0.0013^{* *}$ & $0.0014^{* *}$ & $0.0015^{* *}$ & $0.0015 * *$ \\
\hline & $(0.0001)$ & $(0.0001)$ & $(0.0001)$ & $(0.0001)$ & $(0.0001)$ & $(0.0001)$ & $(0.0001)$ & $(0.0001)$ & $(0.0001)$ & $(0.0001)$ & $(0.0001)$ & $(0.0001)$ \\
\hline \multirow[t]{2}{*}{ Service } & $0.0014 * *$ & $0.0014 * *$ & $0.0014 * *$ & $0.0013 * *$ & $0.0013^{* *}$ & $0.0013 * *$ & $0.0012 * *$ & $0.0013 * *$ & $0.0012 * *$ & $0.0013 * *$ & $0.0014 * *$ & $0.0014 * *$ \\
\hline & $(0.0001)$ & $(0.0001)$ & $(0.0001)$ & $(0.0001)$ & $(0.0001)$ & $(0.0001)$ & $(0.0001)$ & $(0.0001)$ & $(0.0001)$ & $(0.0001)$ & $(0.0001)$ & $(0.0001)$ \\
\hline Capital dummy & $(0.0022)$ & $(0.0022)$ & $(0.0022)$ & $(0.0022)$ & $(0.0022)$ & $(0.0022)$ & $(0.0022)$ & $(0.0022)$ & $(0.0022)$ & $(0.0022)$ & $(0.0022)$ & $(0.0022)$ \\
\hline \multirow[t]{2}{*}{ Costal dummy } & 0.0003 & 0.0003 & 0.0004 & 0.0005 & 0.0002 & 0.0003 & 0.0003 & 0.0004 & 0.0003 & 0.0004 & 0.0004 & 0.0003 \\
\hline & $(0.0013)$ & $(0.0013)$ & $(0.0013)$ & $(0.0013)$ & $(0.0013)$ & $(0.0013)$ & $(0.0013)$ & $(0.0013)$ & $(0.0013)$ & $(0.0013)$ & $(0.0013)$ & $(0.0013)$ \\
\hline \multirow[t]{2}{*}{ Port dummy } & -0.0004 & -0.0005 & -0.0006 & -0.0004 & -0.0003 & -0.0004 & -0.0003 & -0.0004 & -0.0003 & -0.0004 & -0.0005 & -0.0004 \\
\hline & $(0.0012)$ & $(0.0012)$ & $(0.0012)$ & $(0.0012)$ & $(0.0012)$ & $(0.0012)$ & $(0.0012)$ & $(0.0012)$ & $(0.0012)$ & $(0.0012)$ & $(0.0012)$ & $(0.0012)$ \\
\hline \multirow[t]{2}{*}{ Urban dummy } & -0.0008 & -0.0007 & -0.0005 & -0.0009 & -0.0007 & -0.0010 & -0.0010 & -0.0007 & -0.0010 & -0.0007 & -0.0005 & -0.0006 \\
\hline & $(0.0012)$ & $(0.0012)$ & $(0.0012)$ & $(0.0011)$ & $(0.0012)$ & $(0.0011)$ & $(0.0011)$ & $(0.0012)$ & $(0.0011)$ & $(0.0012)$ & $(0.0012)$ & $(0.0012)$ \\
\hline \multirow[t]{2}{*}{ Rural dummy } & $-2,310 \mathrm{e}-06$ & 0.0002 & $-9,679 \mathrm{e}-05$ & 0.0006 & $-1,993 \mathrm{e}-05$ & 0.0004 & 0.0005 & 0.0001 & 0.0005 & 0.00011 & -0.0002 & -0.0002 \\
\hline & $(0.0011)$ & $(0.0011)$ & $(0.0011)$ & $(0.0011)$ & $(0.0011)$ & $(0.0011)$ & $(0.0011)$ & $(0.0011)$ & $(0.0011)$ & $(0.0011)$ & $(0.0011)$ & $(0.0011)$ \\
\hline \multirow{2}{*}{$\begin{array}{l}\text { Post-policy period } \\
\text { dummy }(t 2)\end{array}$} & $-0.0188 * *$ & $-0.0220 * *$ & $-0.0197 * *$ & $-0.0216^{* *}$ & $-0.0173^{* *}$ & $-0.0213 * *$ & $-0.0213 * *$ & $-0.0228 * *$ & $-0.0213 * *$ & $-0.0228 * *$ & $-0.0234 * *$ & $-0.0233^{* *}$ \\
\hline & $(0.0013)$ & $(0.0010)$ & $(0.0017)$ & $(0.0009)$ & $(0.0016)$ & $(0.0009)$ & $(0.0010)$ & $(0.0009)$ & $(0.0010)$ & $(0.0009)$ & $(0.0009)$ & $(0.0009)$ \\
\hline \multirow{2}{*}{$\begin{array}{l}\text { Treatment group } \\
\text { dummy }(d T)\end{array}$} & $0.0039 * *$ & & $0.0043 * *$ & & $0.0037 * *$ & & $0.0146 * *$ & & $0.0146 * *$ & & $0.0100 * *$ & \\
\hline & $(0.0012)$ & & $(0.0014)$ & & $(0.0014)$ & & $(0.0027)$ & & $(0.0027)$ & & $(0.0035)$ & \\
\hline $\begin{array}{l}\text { Difference-in-difference } \\
\text { estimator }(t 2 \times d T)\end{array}$ & $-0.0080 * *$ & & $-0.0046^{* *}$ & & $-0.0081 * *$ & & $-0.0135 * *$ & & $-0.0135^{* *}$ & & 0.0044 & \\
\hline $\begin{array}{l}\text { Treatment intensity } \\
\text { (Tint) }\end{array}$ & & $(0.0294)$ & & $(0.0010)$ & & $(0.0347)$ & & $(0.0024)$ & & $(0.0024)$ & & $(0.1366)$ \\
\hline \multirow{2}{*}{$\begin{array}{l}\text { Post-policy period } \\
\text { dummy } * \text { Treatment } \\
\text { intensity }(t 2 \times \text { Tint })\end{array}$} & & $-0.2089 * *$ & & $-0.0084 * *$ & & $-0.3544 * *$ & & $-0.0082 * *$ & & $-0.0084^{* *}$ & & $0.2731^{*}$ \\
\hline & & $(0.0395)$ & & $(0.0011)$ & & $(0.0416)$ & & $(0.0029)$ & & $(0.0029)$ & & $(0.1394)$ \\
\hline $\mathbf{n}$ & 2502 & 2502 & 2502 & 2502 & 2502 & 2502 & 2502 & 2502 & 2502 & 2502 & 2502 & 2502 \\
\hline$\overline{\mathbf{R}^{2}}$ & 0.4826 & 0.4843 & 0.4794 & 0.4918 & 0.4816 & 0.4927 & 0.4880 & 0.4803 & 0.4880 & 0.4804 & 0.4808 & 0.4783 \\
\hline
\end{tabular}

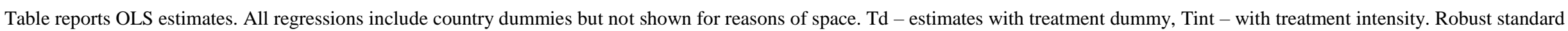
errors are reported in parentheses. * indicates significance at the 10 percent level, ** indicates significance at the 5 percent level 
Table D1. (continued)

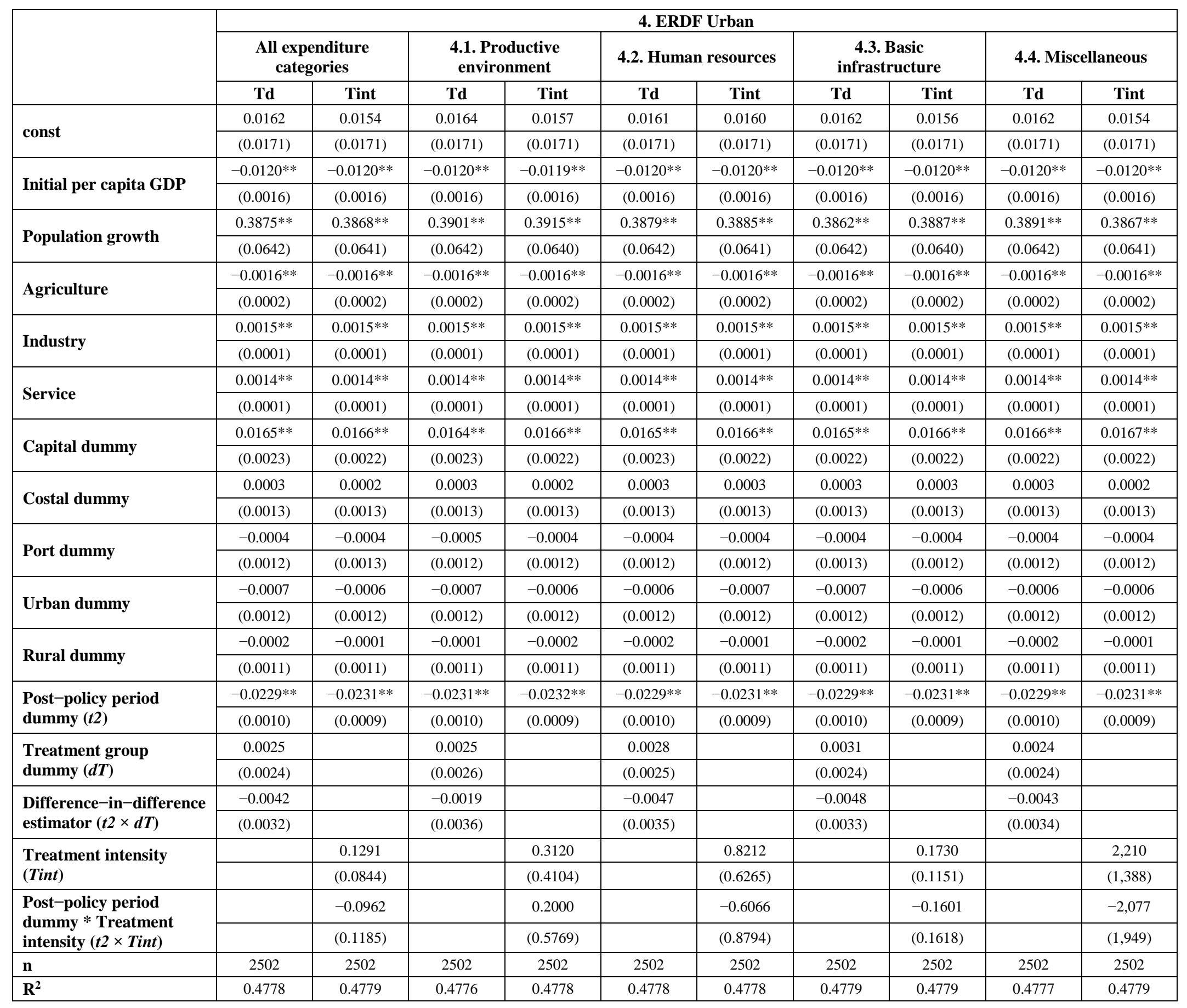

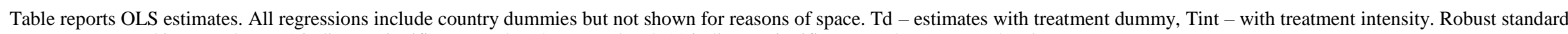
errors are reported in parentheses. * indicates significance at the 10 percent level, ** indicates significance at the 5 percent level 
Table D1. (continued)

\begin{tabular}{|c|c|c|c|c|c|c|c|c|c|c|}
\hline & \multicolumn{10}{|c|}{ 5. ERDF INTERREG IIIA } \\
\hline & \multicolumn{2}{|c|}{$\begin{array}{c}\text { All expenditure } \\
\text { categories }\end{array}$} & \multicolumn{2}{|c|}{$\begin{array}{c}\text { 5.1. Productive } \\
\text { environment }\end{array}$} & \multicolumn{2}{|c|}{ 5.2. Human resources } & \multicolumn{2}{|c|}{$\begin{array}{c}\text { 5.3. Basic } \\
\text { infrastructure }\end{array}$} & \multicolumn{2}{|c|}{ 5.4. Miscellaneous } \\
\hline & Td & Tint & Td & Tint & Td & Tint & Td & Tint & Td & Tint \\
\hline \multirow{2}{*}{ const } & 0.0164 & 0.0172 & 0.0164 & 0.0164 & 0.0162 & 0.0168 & 0.0164 & 0.0177 & 0.0164 & 0.0167 \\
\hline & $(0.0171)$ & $(0.0171)$ & $(0.0171)$ & $(0.0171)$ & $(0.0171)$ & $(0.0172)$ & $(0.0171)$ & $(0.0171)$ & $(0.0171)$ & $(0.0171)$ \\
\hline \multirow{2}{*}{ Initial per capita GDP } & $-0.0120^{* *}$ & $-0.0121 * *$ & $-0.0120 * *$ & $-0.0120 * *$ & $-0.0120 * *$ & $-0.0120 * *$ & $-0.0120 * *$ & $-0.0121 * *$ & $-0.0120 * *$ & $-0.0120 * *$ \\
\hline & $(0.0016)$ & $(0.0016)$ & $(0.0016)$ & $(0.0016)$ & $(0.0016)$ & $(0.0016)$ & $(0.0016)$ & $(0.0016)$ & $(0.0016)$ & $(0.0016)$ \\
\hline \multirow{2}{*}{ Population growth } & $0.3979 * *$ & $0.3986 * *$ & $0.3979 * *$ & $0.3982 * *$ & $0.3973 * *$ & $0.3989 * *$ & $0.3979 * *$ & $0.3993^{* *}$ & $0.3978^{* *}$ & $0.3967 * *$ \\
\hline & $(0.0638)$ & $(0.0638)$ & $(0.0638)$ & $(0.0638)$ & $(0.0638)$ & $(0.0638)$ & $(0.0638)$ & $(0.0637)$ & $(0.0638)$ & $(0.0638)$ \\
\hline \multirow{2}{*}{ Agriculture } & $-0.0016^{* *}$ & $-0.0016^{* *}$ & $-0.0016^{* *}$ & $-0.0016^{* *}$ & $-0.0016^{* *}$ & $-0.0016^{* *}$ & $-0.0016^{* *}$ & $-0.0015^{* *}$ & $-0.0016^{* *}$ & $-0.0016^{* *}$ \\
\hline & $(0.0002)$ & $(0.0002)$ & $(0.0002)$ & $(0.0002)$ & $(0.0002)$ & $(0.0002)$ & $(0.0002)$ & $(0.0002)$ & $(0.0002)$ & $(0.0002)$ \\
\hline \multirow{2}{*}{ Industry } & $0.0015^{* *}$ & $0.0015^{* *}$ & $0.0015^{* *}$ & $0.0015^{* *}$ & $0.0015 * *$ & $0.0015 * *$ & $0.0014 * *$ & $0.0015^{* *}$ & $0.0015^{* * *}$ & $0.0015^{* *}$ \\
\hline & $(0.0001)$ & $(0.0001)$ & $(0.0001)$ & $(0.0001)$ & $(0.0001)$ & $(0.0001)$ & $(0.0001)$ & $(0.0001)$ & $(0.0001)$ & (0.0001) \\
\hline \multirow{2}{*}{ Service } & $0.0014 * *$ & $0.0014 * *$ & $0.0014 * *$ & $0.0014 * *$ & $0.0014 * *$ & $0.0014 * *$ & $0.0014 * *$ & $0.0014^{* *}$ & $0.0014^{* *}$ & $0.0014 * *$ \\
\hline & $(0.0001)$ & $(0.0001)$ & $(0.0001)$ & $(0.0001)$ & $(0.0001)$ & $(0.0001)$ & $(0.0001)$ & $(0.0001)$ & $(0.0001)$ & $(0.0001)$ \\
\hline \multirow{2}{*}{ Capital dummy } & $0.0166^{* *}$ & $0.0165^{* *}$ & $0.0166^{* *}$ & $0.0166^{* * *}$ & $0.0166 * *$ & $0.0166 * *$ & $0.0166^{* *}$ & $0.0165^{* *}$ & $0.0166^{* *}$ & $0.0166^{* *}$ \\
\hline & $(0.0022)$ & $(0.0022)$ & $(0.0022)$ & $(0.0022)$ & $(0.0022)$ & $(0.0022)$ & $(0.0022)$ & $(0.0022)$ & $(0.0022)$ & $(0.0022)$ \\
\hline \multirow{2}{*}{ Costal dummy } & 0.0003 & 0.0003 & 0.0003 & 0.0003 & 0.0003 & 0.0003 & 0.0003 & 0.0003 & 0.0003 & 0.0003 \\
\hline & $(0.0013)$ & $(0.0013)$ & $(0.0013)$ & $(0.0013)$ & $(0.0013)$ & $(0.0013)$ & $(0.0013)$ & $(0.0013)$ & $(0.0013)$ & $(0.0013)$ \\
\hline \multirow{2}{*}{ Port dummy } & -0.0004 & -0.0004 & -0.0004 & -0.0004 & -0.0004 & -0.0004 & -0.0004 & -0.0004 & -0.0004 & -0.0004 \\
\hline & $(0.0012)$ & $(0.0012)$ & $(0.0012)$ & $(0.0012)$ & $(0.0012)$ & $(0.0012)$ & $(0.0012)$ & $(0.0012)$ & $(0.0012)$ & $(0.0012)$ \\
\hline \multirow{2}{*}{ Urban dummy } & -0.0007 & -0.0007 & -0.0007 & -0.0007 & -0.0006 & -0.0007 & -0.0007 & -0.0008 & -0.0007 & -0.0007 \\
\hline & $(0.0012)$ & $(0.0012)$ & $(0.0012)$ & $(0.0012)$ & $(0.0012)$ & $(0.0012)$ & $(0.0012)$ & $(0.0012)$ & $(0.0012)$ & $(0.0012)$ \\
\hline \multirow{2}{*}{ Rural dummy } & -0.0002 & $-8,269 \mathrm{e}-05$ & -0.0002 & -0.0002 & -0.0002 & -0.0002 & -0.0002 & $4,754 \mathrm{e}-05$ & -0.0002 & -0.0002 \\
\hline & $(0.0011)$ & $(0.0011)$ & $(0.0011)$ & $(0.0011)$ & $(0.0011)$ & $(0.0011)$ & $(0.0011)$ & $(0.0011)$ & $(0.0011)$ & $(0.0011)$ \\
\hline \multirow{2}{*}{$\begin{array}{l}\text { Post-policy period } \\
\text { dummy }(t 2)\end{array}$} & $-0.0228 * *$ & $-0.0228 * *$ & $-0.0228 * *$ & $-0.0233 * *$ & $-0.0230 * *$ & $-0.0230 * *$ & $-0.0228 * *$ & $-0.0226 * *$ & $-0.0228 * *$ & $-0.0231 * *$ \\
\hline & $(0.0011)$ & $(0.0009)$ & $(0.0011)$ & $(0.0009)$ & $(0.0011)$ & $(0.0010)$ & $(0.0011)$ & $(0.0009)$ & $(0.0011)$ & $(0.0010)$ \\
\hline \multirow{2}{*}{$\begin{array}{l}\text { Treatment group } \\
\text { dummy }(d T)\end{array}$} & 0.0005 & & 0.0005 & & 0.0003 & & 0.0005 & & 0.0004 & \\
\hline & $(0.0013)$ & & $(0.0013)$ & & $(0.0013)$ & & $(0.0013)$ & & $(0.0013)$ & \\
\hline \multirow{2}{*}{$\begin{array}{l}\text { Difference-in-difference } \\
\text { estimator }(t 2 \times d T)\end{array}$} & -0.0014 & & -0.0014 & & -0.0006 & & -0.0014 & & -0.0014 & \\
\hline & $(0.0017)$ & & $(0.0017)$ & & $(0.0017)$ & & $(0.0018)$ & & $(0.0017)$ & \\
\hline \multirow{2}{*}{$\begin{array}{l}\text { Treatment intensity } \\
\text { (Tint) }\end{array}$} & & 0.0175 & & -0.0256 & & 0.0768 & & $0.0753^{* * *}$ & & 0.0586 \\
\hline & & $(0.0146)$ & & $(0.0319)$ & & $(0.2361)$ & & $(0.0273)$ & & $(0.1822)$ \\
\hline \multirow{2}{*}{$\begin{array}{l}\text { Post-policy period } \\
\text { dummy * Treatment } \\
\text { intensity }(t 2 \times \text { Tint })\end{array}$} & & $-0.0395 * *$ & & 0.0230 & & -0.3083 & & $-0.1421^{* *}$ & & -0.1611 \\
\hline & & $(0.0196)$ & & $(0.0440)$ & & $(0.3213)$ & & $(0.0361)$ & & $(0.2419)$ \\
\hline $\mathrm{n}$ & 2502 & 2502 & 2502 & 2502 & 2502 & 2502 & 2502 & 2502 & 2502 & 2502 \\
\hline $\mathbf{R}^{2}$ & 0.4775 & 0.4783 & 0.4775 & 0.4775 & 0.4774 & 0.4776 & 0.4775 & 0.4807 & 0.4776 & 0.4775 \\
\hline
\end{tabular}

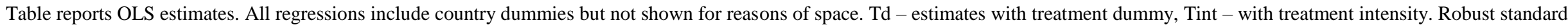
errors are reported in parentheses. * indicates significance at the 10 percent level, $* *$ indicates significance at the 5 percent level 
Table D2. Estimations for 2007-2012 post-policy period

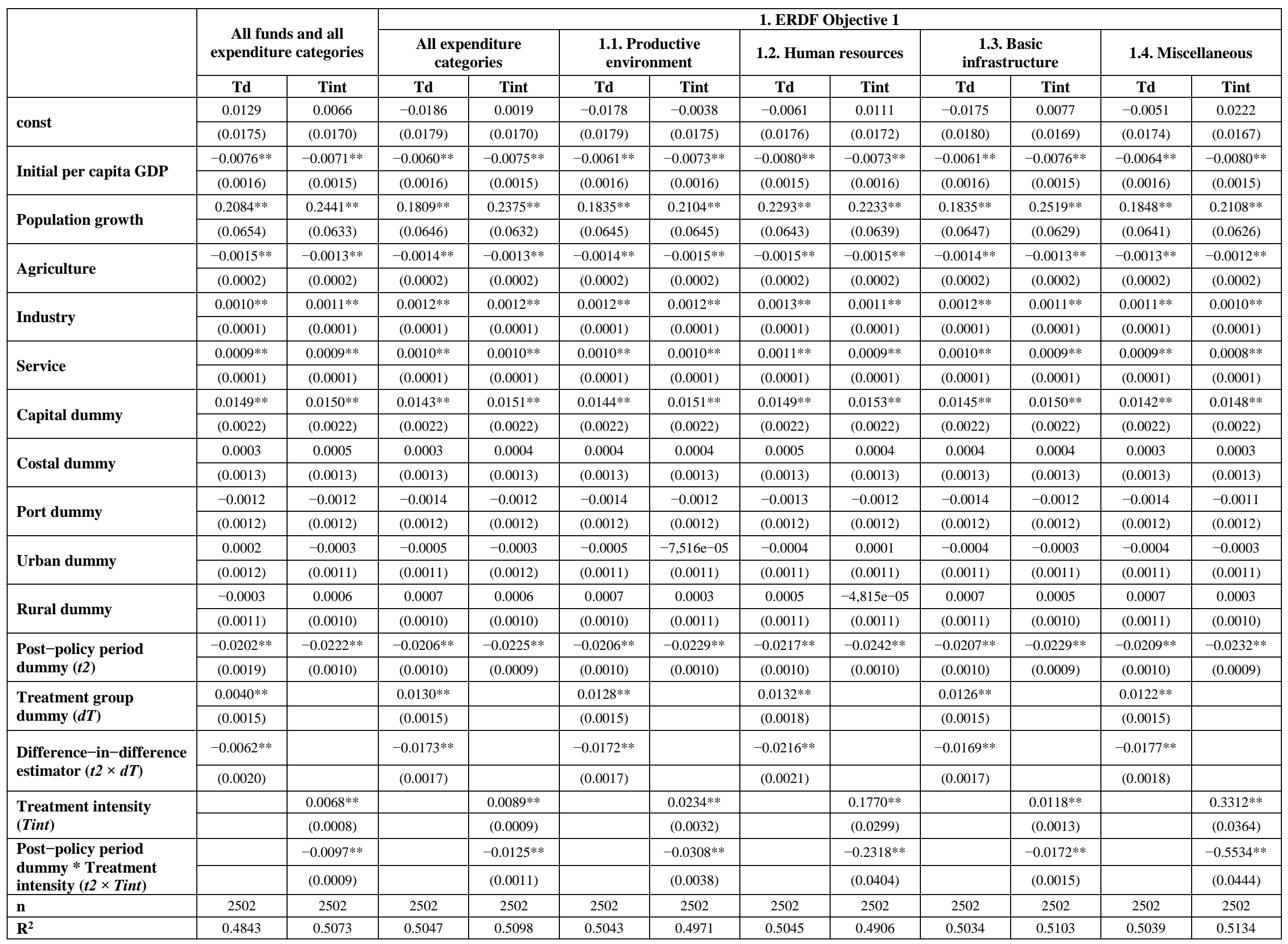

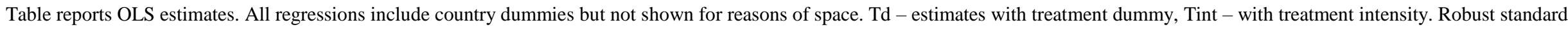
errors are reported in parentheses. * indicates significance at the 10 percent level, $* *$ indicates significance at the 5 percent level 
Table D2. (continued)

\begin{tabular}{|c|c|c|c|c|c|c|c|c|c|c|c|c|}
\hline & \multirow{2}{*}{\multicolumn{2}{|c|}{$\begin{array}{c}\text { Productive } \\
\text { environment (all funds } \\
\text { ERDF+CF) }\end{array}$}} & \multicolumn{10}{|c|}{ 2. ERDF Objective 2} \\
\hline & & & \multicolumn{2}{|c|}{$\begin{array}{l}\text { All expenditure } \\
\text { categories }\end{array}$} & \multicolumn{2}{|c|}{$\begin{array}{l}\text { 2.1. Productive } \\
\text { environment }\end{array}$} & \multicolumn{2}{|c|}{ 2.2. Human resources } & \multicolumn{2}{|c|}{$\begin{array}{c}\text { 2.3. Basic } \\
\text { infrastructure }\end{array}$} & \multicolumn{2}{|c|}{ 2.4. Miscellaneous } \\
\hline & Td & Tint & Td & Tint & Td & Tint & Td & Tint & Td & Tint & Td & Tint \\
\hline \multirow{2}{*}{ const } & 0.0125 & 0.0010 & 0.0097 & 0.0147 & 0.0100 & 0.0162 & 0.0190 & 0.0193 & 0.0120 & 0.0144 & 0.0111 & 0.0165 \\
\hline & $(0.0175)$ & $(0.0176)$ & $(0.0172)$ & $(0.0171)$ & $(0.0172)$ & $(0.0171)$ & $(0.0172)$ & $(0.0172)$ & $(0.0172)$ & $(0.0172)$ & $(0.0172)$ & $(0.0172)$ \\
\hline \multirow{2}{*}{ Initial per capita GDP } & $-0.0075^{* *}$ & $-0.0075^{* *}$ & $-0.0069^{* *}$ & $-0.0073^{* *}$ & $-0.0069^{* *}$ & $-0.0075^{* *}$ & $-0.0074 * *$ & $-0.0075^{* *}$ & $-0.0070 * *$ & $-0.0072^{* * *}$ & $-0.0071^{* *}$ & $-0.0073 * *$ \\
\hline & $(0.0016)$ & $(0.0016)$ & $(0.0016)$ & $(0.0016)$ & $(0.0016)$ & $(0.0016)$ & $(0.0016)$ & $(0.0016)$ & $(0.0016)$ & $(0.0016)$ & $(0.0016)$ & $(0.0016)$ \\
\hline Population growth & $(0.0654)$ & $(0.0651)$ & $(0.0642)$ & $(0.0647)$ & $(0.0642)$ & $(0.0646)$ & $(0.0646)$ & $(0.0645)$ & $(0.0643)$ & $(0.0647)$ & $(0.0647)$ & $(0.0645)$ \\
\hline \multirow{2}{*}{ Agriculture } & $-0.0015 * *$ & $-0.0015^{* *}$ & $-0.0015 * *$ & $-0.0015^{* *}$ & $-0.0015^{* *}$ & $-0.0015 * *$ & $-0.0015^{* *}$ & $-0.0015^{* *}$ & $-0.0015^{* *}$ & $-0.0015^{* *}$ & $-0.0015^{* *}$ & $-0.0015 * *$ \\
\hline & $(0.0002)$ & $(0.0002)$ & $(0.0002)$ & $(0.0002)$ & $(0.0002)$ & $(0.0002)$ & $(0.0002)$ & $(0.0002)$ & $(0.0002)$ & $(0.0002)$ & $(0.0002)$ & $(0.0002)$ \\
\hline \multirow{2}{*}{ Industry } & $0.0010^{* *}$ & $0.0012^{* *}$ & $0.0011 * *$ & $0.0010^{* *}$ & $0.0011^{* *}$ & $0.0010^{* *}$ & $0.0010^{* *}$ & $0.0010^{* *}$ & $0.0010^{* *}$ & $0.0010^{* *}$ & $0.0011^{* *}$ & $0.0010^{* *}$ \\
\hline & $(0.0001)$ & $(0.0001)$ & $(0.0001)$ & $(0.0001)$ & $(0.0001)$ & $(0.0001)$ & $(0.0001)$ & $(0.0001)$ & $(0.0001)$ & $(0.0001)$ & $(0.0001)$ & $(0.0001)$ \\
\hline \multirow{2}{*}{ Service } & $0.0009 * *$ & $0.0010^{* *}$ & $0.0009 * *$ & $0.0009^{* *}$ & $0.0009 * *$ & $0.0009 * *$ & $0.0008^{* *}$ & $0.0008^{* *}$ & $0.0009 * *$ & $0.0008 * *$ & $0.0009 * *$ & $0.0008^{* *}$ \\
\hline & $(0.0001)$ & $(0.0001)$ & $(0.0001)$ & $(0.0001)$ & $(0.0001)$ & $(0.0001)$ & $(0.0001)$ & $(0.0001)$ & $(0.0001)$ & $(0.0001)$ & $(0.0001)$ & $(0.0001)$ \\
\hline Capital dummy & $(0.0022)$ & $(0.0022)$ & $(0.0022)$ & $(0.0022)$ & $(0.0022)$ & $(0.0022)$ & $(0.0022)$ & $(0.0022)$ & $(0.0022)$ & $(0.0022)$ & $(0.0022)$ & $(0.0022)$ \\
\hline \multirow{2}{*}{ Costal dummy } & 0.0003 & 0.0003 & 0.0003 & 0.0005 & 0.0004 & 0.0006 & 0.0004 & 0.0006 & 0.0003 & 0.0004 & 0.0003 & 0.0002 \\
\hline & $(0.0013)$ & $(0.0013)$ & $(0.0013)$ & $(0.0013)$ & $(0.0013)$ & $(0.0013)$ & $(0.0013)$ & $(0.0013)$ & $(0.0013)$ & $(0.0013)$ & $(0.0013)$ & $(0.0013)$ \\
\hline \multirow{2}{*}{ Port dummy } & -0.0012 & -0.0012 & -0.0011 & -0.0012 & -0.0011 & -0.0011 & -0.0011 & -0.0013 & -0.0012 & -0.0012 & -0.0011 & -0.0011 \\
\hline & $(0.0012)$ & $(0.0012)$ & $(0.0012)$ & $(0.0012)$ & $(0.0012)$ & $(0.0012)$ & $(0.0012)$ & $(0.0012)$ & $(0.0012)$ & $(0.0012)$ & $(0.0012)$ & $(0.0012)$ \\
\hline \multirow{2}{*}{ Urban dummy } & 0.0003 & $-1,148 \mathrm{e}-06$ & -0.0001 & $-3,427 \mathrm{e}-05$ & -0.0001 & $-9,877 \mathrm{e}-05$ & 0.0004 & 0.0003 & $3,404 \mathrm{e}-08$ & 0.0001 & 0.0001 & 0.0004 \\
\hline & $(0.0012)$ & $(0.0011)$ & $(0.0011)$ & $(0.0011)$ & $(0.0011)$ & $(0.0011)$ & $(0.0012)$ & $(0.0012)$ & $(0.0011)$ & $(0.0012)$ & $(0.0012)$ & $(0.0012)$ \\
\hline \multirow{2}{*}{ Rural dummy } & -0.0003 & $9,563 \mathrm{e}-05$ & $-4,652 \mathrm{e}-06$ & $4,451 \mathrm{e}-06$ & $-1,636 \mathrm{e}-05$ & $5,672 \mathrm{e}-05$ & -0.0005 & -0.0004 & -0.0002 & -0.0003 & -0.0002 & -0.0002 \\
\hline & $(0.0011)$ & $(0.0011)$ & $(0.0011)$ & $(0.0011)$ & $(0.0011)$ & $(0.0011)$ & $(0.0011)$ & $(0.0011)$ & $(0.0011)$ & $(0.0011)$ & $(0.0011)$ & $(0.0011)$ \\
\hline \multirow{2}{*}{$\begin{array}{l}\text { Post-policy period } \\
\text { dummy }(t 2)\end{array}$} & $-0.0200 * *$ & $-0.022 * *$ & $-0.0291 * *$ & $-0.0270^{* *}$ & $-0.0290 * *$ & $-0.0270 * *$ & $-0.0245^{* *}$ & $-0.0247 * *$ & $-0.0282 * *$ & $-0.0260 * *$ & $-0.0269 * *$ & $-0.0258 * *$ \\
\hline & $(0.0019)$ & $(0.0010)$ & $(0.0012)$ & $(0.0011)$ & $(0.0012)$ & $(0.0010)$ & $(0.0010)$ & $(0.0010)$ & $(0.0012)$ & $(0.0010)$ & $(0.0011)$ & $(0.0010)$ \\
\hline \multirow{2}{*}{$\begin{array}{l}\text { Treatment group } \\
\text { dummy }(d T)\end{array}$} & $0.0042 * *$ & & $-0.0060 * *$ & & $-0.0059 * *$ & & -0.0007 & & $-0.0040^{* *}$ & & $-0.0046^{* *}$ & \\
\hline & $(0.0015)$ & & $(0.0013)$ & & $(0.0013)$ & & $(0.0017)$ & & $(0.0013)$ & & $(0.0013)$ & \\
\hline \multirow{2}{*}{$\begin{array}{l}\text { Treatment intensity } \\
\text { (Tint) }\end{array}$} & & 0.0197 ** & & $-0.0453^{* *}$ & & $-0.0707 * *$ & & -0.0744 & & $-0.0557^{* *} *$ & & $-0.7912 * *$ \\
\hline & & $(0.0033)$ & & $(0.0099)$ & & $(0.014)$ & & $(0.2089)$ & & $(0.0246)$ & & $(0.2364)$ \\
\hline \multirow{2}{*}{$\begin{array}{l}\text { Post-policy period } \\
\text { dummy } * \text { Treatment } \\
\text { intensity }(t 2 \times \text { Tint })\end{array}$} & & $-0.0277^{* *}$ & & $0.0524 * *$ & & $0.0797 * *$ & & $-0.5636^{* *}$ & & $0.0819 * *$ & & $0.8985 * *$ \\
\hline & & $(0.0039)$ & & $(0.0133)$ & & $(0.0190)$ & & $(0.2694)$ & & $(0.0332)$ & & $(0.325)$ \\
\hline n & 2502 & 2502 & 2502 & 2502 & 2502 & 2502 & 2502 & 2502 & 2502 & 2502 & 2502 & 25 \\
\hline $\mathbf{R}^{2}$ & 0.4845 & 0.4936 & 0.4886 & 0.4868 & 0.4883 & 0.4877 & 0.4834 & 0.4842 & 0.4864 & 0.4836 & 0.4849 & 0.4846 \\
\hline
\end{tabular}

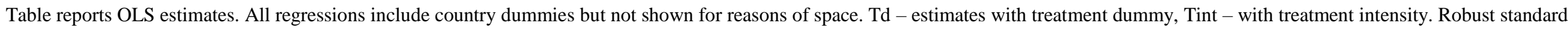
errors are reported in parentheses. * indicates significance at the 10 percent level, $* *$ indicates significance at the 5 percent level 
Table D2. (continued)

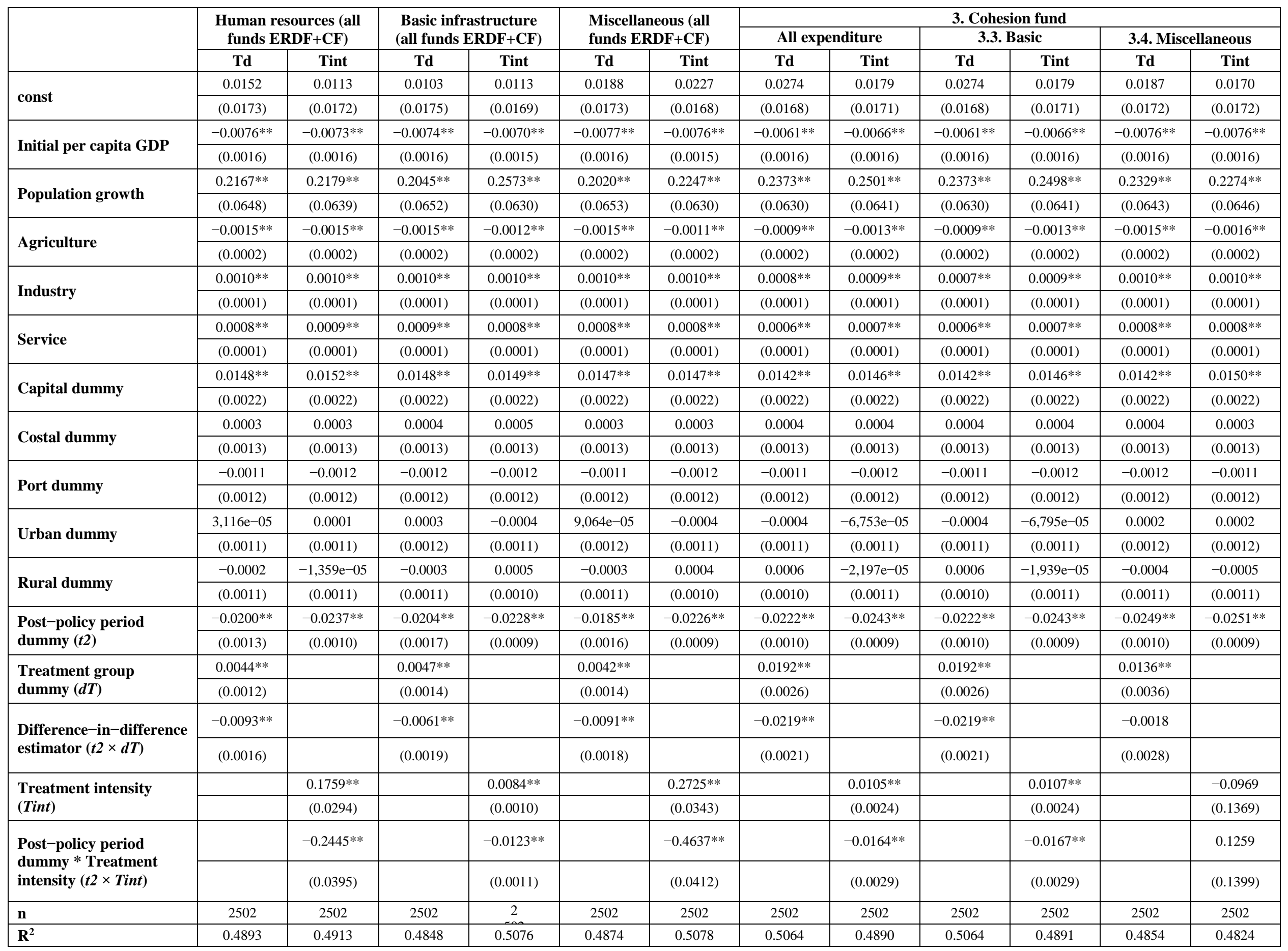

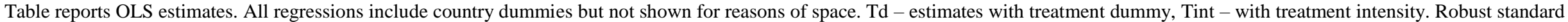
errors are reported in parentheses. * indicates significance at the 10 percent level, ** indicates significance at the 5 percent level 
Table D2. (continued)

\begin{tabular}{|c|c|c|c|c|c|c|c|c|c|c|}
\hline & \multicolumn{10}{|c|}{ 4. ERDF Urban } \\
\hline & \multicolumn{2}{|c|}{$\begin{array}{l}\text { All expenditure } \\
\text { categories }\end{array}$} & \multicolumn{2}{|c|}{$\begin{array}{l}\text { 4.1. Productive } \\
\text { environment }\end{array}$} & \multicolumn{2}{|c|}{ 4.2. Human resources } & \multicolumn{2}{|c|}{$\begin{array}{c}\text { 4.3. Basic } \\
\text { infrastructure }\end{array}$} & \multicolumn{2}{|c|}{ 4.4. Miscellaneous } \\
\hline & Td & Tint & Td & Tint & Td & Tint & Td & Tint & Td & Tint \\
\hline \multirow{2}{*}{ const } & 0.0170 & 0.0162 & 0.0172 & 0.0164 & 0.0169 & 0.0169 & 0.0170 & 0.0164 & 0.0170 & 0.0161 \\
\hline & $(0.0172)$ & $(0.0172)$ & $(0.0172)$ & $(0.0172)$ & $(0.0172)$ & $(0.0172)$ & $(0.0172)$ & $(0.0172)$ & $(0.0172)$ & $(0.0172)$ \\
\hline \multirow{2}{*}{ Initial per capita GDP } & $-0.0074 * *$ & $-0.0075^{* *}$ & $-0.0074 * *$ & $-0.0073 * *$ & $-0.0074 * *$ & $-0.0075^{* *}$ & $-0.0074 * *$ & $-0.0075 * *$ & $-0.0074 * *$ & $-0.0075^{* *}$ \\
\hline & $(0.0016)$ & $(0.0016)$ & $(0.0016)$ & $(0.00157)$ & $(0.0016)$ & $(0.0016)$ & $(0.0016)$ & $(0.0016)$ & $(0.0016)$ & $(0.0016)$ \\
\hline \multirow{2}{*}{ Population growth } & $0.2192 * *$ & $0.2202 * *$ & $0.2214 * *$ & $0.2244 * *$ & $0.2194 * *$ & $0.2224 * *$ & $0.2185^{* *}$ & $0.2228 * *$ & $0.2207 * *$ & $0.2198 * *$ \\
\hline & $(0.0648)$ & $(0.0647)$ & $(0.0649)$ & $(0.0646)$ & $(0.0648)$ & $(0.0647)$ & $(0.0648)$ & $(0.0646)$ & $(0.0649)$ & $(0.0647)$ \\
\hline \multirow{2}{*}{ Agriculture } & $-0.0016^{* *}$ & $-0.0016^{* *}$ & $-0.0016^{* *}$ & $-0.0016^{* *}$ & $-0.0016^{* *}$ & $-0.0016^{* *}$ & $-0.0016^{* *}$ & $-0.0016^{* *}$ & $-0.0016^{* *}$ & $-0.0016^{* *}$ \\
\hline & $(0.0002)$ & $(0.0002)$ & $(0.0002)$ & $(0.0002)$ & $(0.0002)$ & $(0.0002)$ & $(0.0002)$ & $(0.0002)$ & (0.0002) & $(0.0002)$ \\
\hline \multirow{2}{*}{ Industry } & $0.0010 * *$ & $0.0010^{* *}$ & $0.0010 * *$ & $0.0010 * *$ & $0.0010^{* *}$ & $0.0010 * *$ & $0.0010^{* *}$ & $0.0010 * *$ & $0.0010 * *$ & $0.0010^{* *}$ \\
\hline & $(0.0001)$ & $(0.0001)$ & $(0.0001)$ & $(0.00014)$ & $(0.0001)$ & $(0.0001)$ & $(0.0001)$ & $(0.0001)$ & $\begin{array}{l}(0.0001) \\
\end{array}$ & $(0.0001)$ \\
\hline \multirow{2}{*}{ Service } & $0.0008 * *$ & $0.0008^{* *}$ & $0.0008 * *$ & $0.0008 * *$ & $0.0008^{* *}$ & $0.0008 * *$ & $0.0008 * *$ & $0.0008 * *$ & $0.0008 * *$ & $0.0008^{* * *}$ \\
\hline & $(0.0001)$ & $(0.0001)$ & $(0.0001)$ & $(0.0001)$ & $(0.0001)$ & $(0.0001)$ & $(0.0001)$ & $(0.0001)$ & $(0.0001)$ & $(0.0001)$ \\
\hline \multirow{2}{*}{ Capital dummy } & $0.0149 * *$ & $0.0150^{* *}$ & $0.0147 * *$ & $0.0150^{* *}$ & $0.0149^{* *}$ & $0.0150^{* *}$ & $0.0148^{* *}$ & $0.0150^{* *}$ & $0.0149 * *$ & $0.0150^{* *}$ \\
\hline & $(0.0023)$ & $(0.0022)$ & $(0.0023)$ & $(0.0022)$ & $(0.0023)$ & $(0.0022)$ & $(0.0023)$ & $(0.0022)$ & $(0.0022)$ & $(0.0022)$ \\
\hline \multirow{2}{*}{ Costal dummy } & 0.0003 & 0.0003 & 0.0003 & 0.0002 & 0.0003 & 0.0003 & 0.0003 & 0.0003 & 0.0003 & 0.0003 \\
\hline & $(0.0013)$ & $(0.0013)$ & $(0.0013)$ & $(0.0013)$ & $(0.0013)$ & $(0.0013)$ & $(0.0013)$ & $(0.0013)$ & $(0.0013)$ & $(0.0013)$ \\
\hline \multirow{2}{*}{ Port dummy } & -0.0012 & -0.0011 & -0.0012 & -0.0012 & -0.0012 & -0.0012 & -0.0012 & -0.0011 & -0.0011 & -0.0011 \\
\hline & $(0.0012)$ & $(0.0012)$ & $(0.0012)$ & $(0.0012)$ & $(0.0012)$ & $(0.0012)$ & $(0.0012)$ & $(0.0012)$ & $(0.0012)$ & $(0.0012)$ \\
\hline \multirow{2}{*}{ Urban dummy } & 0.0002 & 0.0002 & 0.0002 & 0.0002 & 0.0002 & 0.0002 & 0.0002 & 0.00022 & 0.0002 & 0.0002 \\
\hline & $(0.0012)$ & $(0.0012)$ & $(0.0012)$ & $(0.0012)$ & $(0.0012)$ & $(0.0012)$ & $(0.0012)$ & $(0.0012)$ & $(0.0012)$ & $(0.0012)$ \\
\hline \multirow{2}{*}{ Rural dummy } & -0.0004 & -0.0004 & -0.0004 & -0.0004 & -0.0004 & -0.0004 & -0.0004 & -0.0004 & -0.0004 & -0.0004 \\
\hline & $(0.0011)$ & $(0.0011)$ & $(0.0011)$ & $(0.0011)$ & $(0.0011)$ & $(0.0011)$ & $(0.0011)$ & $(0.0011)$ & $(0.0011)$ & $(0.0011)$ \\
\hline \multirow{2}{*}{$\begin{array}{l}\text { Post-policy period } \\
\text { dummy }(t 2)\end{array}$} & $-0.0247 * *$ & $-0.0250 * *$ & $-0.0249 * *$ & $-0.0252 * *$ & $-0.0247 * *$ & $-0.0250^{* *}$ & $-0.0247 * *$ & $-0.0249 * *$ & $-0.0247 * *$ & $-0.0249 * *$ \\
\hline & $(0.0010)$ & $(0.0009)$ & $(0.0010)$ & $(0.0009)$ & $(0.0010)$ & $(0.0010)$ & $(0.0010)$ & $(0.0009)$ & $(0.0010)$ & $(0.0009)$ \\
\hline \multirow{2}{*}{$\begin{array}{l}\text { Treatment group } \\
\text { dummy }(d T)\end{array}$} & 0.0033 & & 0.0035 & & 0.0037 & & 0.0038 & & 0.0033 & \\
\hline & $(0.0024)$ & & $(0.0026)$ & & $(0.0025)$ & & $(0.0024)$ & & $(0.0024)$ & \\
\hline \multirow{2}{*}{$\begin{array}{l}\text { Difference-in-difference } \\
\text { estimator }(t 2 \times d T)\end{array}$} & $-0.0059^{*}$ & & -0.0041 & & $-0.0068^{* *}$ & & $-0.0063^{*}$ & & $-0.0059^{*}$ & \\
\hline & $(0.0032)$ & & $(0.003552)$ & & $(0.0035)$ & & $(0.0033)$ & & $(0.0034)$ & \\
\hline \multirow{2}{*}{$\begin{array}{l}\text { Treatment intensity } \\
\text { (Tint) }\end{array}$} & & $0.1542 *$ & & 0.3669 & & 0.8751 & & $0.2112 *$ & & $2,582^{*}$ \\
\hline & & $(0.0844)$ & & $(0.4107)$ & & $(0.6273)$ & & $(0.1152)$ & & $(1,389)$ \\
\hline \multirow{2}{*}{$\begin{array}{l}\text { Post-policy period } \\
\text { dummy } * \text { Treatment } \\
\text { intensity }(t 2 \times \text { Tint })\end{array}$} & & -0.1378 & & 0.4839 & & -0.4737 & & -0.2622 & & $-2,447$ \\
\hline & & $(0.1186)$ & & $(0.5772)$ & & $(0.8806)$ & & $(0.1620)$ & & $(1,952)$ \\
\hline $\mathrm{n}$ & 2502 & 2502 & 2502 & 2502 & 2502 & 2502 & 2502 & 2502 & 2502 & 2502 \\
\hline $\mathbf{R}^{2}$ & 0.4829 & 0.4829 & 0.4826 & 0.4833 & 0.4830 & 0.4827 & 0.4830 & 0.4829 & 0.4828 & 0.4829 \\
\hline
\end{tabular}

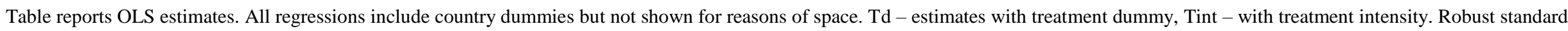
errors are reported in parentheses. * indicates significance at the 10 percent level, $* *$ indicates significance at the 5 percent level 
Table D2. (continued)

\begin{tabular}{|c|c|c|c|c|c|c|c|c|c|c|}
\hline & \multicolumn{10}{|c|}{ 5. ERDF INTERREG IIIA } \\
\hline & \multicolumn{2}{|c|}{$\begin{array}{c}\text { All expenditure } \\
\text { categories }\end{array}$} & \multicolumn{2}{|c|}{$\begin{array}{l}\text { 5.1. Productive } \\
\text { environment }\end{array}$} & \multicolumn{2}{|c|}{ 5.2. Human resources } & \multicolumn{2}{|c|}{ 5.3. Basic infrastructure } & \multicolumn{2}{|c|}{ 5.4. Miscellaneous } \\
\hline & Td & Tint & Td & Tint & Td & Tint & Td & Tint & Td & Tint \\
\hline \multirow{2}{*}{ const } & 0.0175 & 0.0184 & 0.0175 & 0.0177 & 0.0173 & 0.0172 & 0.0175 & 0.0179 & 0.0175 & 0.0188 \\
\hline & $(0.0172)$ & $(0.0172)$ & $(0.0172)$ & $(0.0172)$ & $(0.0172)$ & $(0.0172)$ & $(0.0172)$ & $(0.0171)$ & $(0.0172)$ & $(0.0172)$ \\
\hline \multirow{2}{*}{ Initial per capita GDP } & $-0.0074 * *$ & $-0.0076^{* *}$ & $-0.0074 * *$ & $-0.0075^{* *}$ & $-0.0074 * *$ & $-0.0075^{* *}$ & $-0.0074 * *$ & $-0.0078 * *$ & $-0.0074 * *$ & $-0.0075^{* *}$ \\
\hline & $(0.0016)$ & $(0.0016)$ & $(0.0016)$ & $(0.0016)$ & $(0.0016)$ & $(0.0016)$ & $(0.0016)$ & $(0.0016)$ & $(0.0016)$ & $(0.0016)$ \\
\hline \multirow{2}{*}{ Population growth } & $0.2347 * *$ & $0.2372 * *$ & $0.2347 * *$ & $0.2336^{* *}$ & $0.2341 * *$ & $0.2342 * *$ & $0.2347 * *$ & $0.2416 * *$ & $0.2345^{* *}$ & $0.2308 * *$ \\
\hline & $(0.0644)$ & $(0.0643)$ & $(0.0644)$ & $(0.0645)$ & $(0.0644)$ & $(0.0645)$ & $(0.0644)$ & $(0.0641)$ & $(0.0644)$ & $(0.0644)$ \\
\hline \multirow{2}{*}{ Agriculture } & $-0.0016^{* *}$ & $-0.0015^{* *}$ & $-0.0015^{* *}$ & $-0.0016^{* *}$ & $-0.0015^{* *}$ & $-0.0015^{* *}$ & $-0.0015^{* *}$ & $-0.0014 * *$ & $-0.0015^{* *}$ & $-0.0015^{* *}$ \\
\hline & $(0.0002)$ & $(0.0002)$ & $(0.0002)$ & $(0.0002)$ & $(0.0002)$ & $(0.0002)$ & $(0.0002)$ & $(0.0002)$ & $(0.0002)$ & $(0.0002)$ \\
\hline \multirow{2}{*}{ Industry } & $0.0010^{* *}$ & $0.0010 * *$ & $0.0010^{* *}$ & $0.0010 * *$ & $0.0010 * *$ & $0.0010^{* *}$ & $0.0010 * *$ & $0.0010 * *$ & $0.0010^{* *}$ & $0.0010 * *$ \\
\hline & $(0.0001)$ & $(0.0001)$ & $(0.0001)$ & $(0.0001)$ & $(0.0001)$ & $(0.0001)$ & $(0.0001)$ & $(0.0001)$ & $(0.0001)$ & $(0.0001)$ \\
\hline \multirow{2}{*}{ Service } & $0.0008^{* *}$ & $0.0008^{* *}$ & $0.0008 * *$ & $0.0008^{* *}$ & $0.0008^{* *}$ & $0.0008^{* *}$ & $0.0008 * *$ & $0.0009 * *$ & $0.0008^{* * *}$ & $0.0008^{* *}$ \\
\hline & $(0.0001)$ & $(0.0001)$ & $(0.0001)$ & $(0.0001)$ & $(0.0001)$ & $(0.0001)$ & $(0.0001)$ & $(0.0001)$ & $(0.0001)$ & $(0.0001)$ \\
\hline \multirow{2}{*}{ Capital dummy } & $0.0149 * *$ & $0.0148 * *$ & $0.0149 * *$ & $0.0150 * *$ & $0.0149 * *$ & $0.0149 * *$ & $0.0149 * *$ & $0.0147 * *$ & $0.0149 * *$ & 0.0149 ** \\
\hline & $(0.0022)$ & $\begin{array}{l}0.0022) \\
\end{array}$ & $(0.0022)$ & $(0.0022)$ & $(0.0022)$ & $(0.0022)$ & $(0.0022)$ & $(0.0022)$ & $(0.0022)$ & $(0.0022)$ \\
\hline \multirow{2}{*}{ Costal dummy } & 0.0003 & 0.0003 & 0.0003 & 0.0003 & 0.0003 & 0.0003 & 0.0003 & 0.0003 & 0.0003 & 0.0003 \\
\hline & $(0.0013)$ & $(0.0013)$ & $(0.0013)$ & $(0.0013)$ & $(0.0013)$ & $(0.0013)$ & $(0.0013)$ & $(0.0013)$ & $(0.0013)$ & $(0.0013)$ \\
\hline \multirow{2}{*}{ Port dummy } & -0.0011 & -0.0011 & -0.0011 & -0.0011 & -0.0011 & -0.0011 & -0.0011 & -0.0012 & -0.0011 & -0.0011 \\
\hline & $(0.0012)$ & $(0.0012)$ & $(0.0012)$ & $(0.0012)$ & $(0.0012)$ & $(0.0012)$ & $(0.0012)$ & $(0.0012)$ & $(0.0012)$ & $(0.0012)$ \\
\hline \multirow{2}{*}{ Urban dummy } & $8,521 \mathrm{e}^{-}-05$ & \begin{tabular}{|l|}
$7,561 \mathrm{e}-07$ \\
\end{tabular} & $8,521 \mathrm{e}-05$ & 0.0001 & 0.0001 & 0.0001 & $8,521 \mathrm{e}-05$ & -0.0001 & $8,032 \mathrm{e}-05$ & 0.0001 \\
\hline & $(0.0012)$ & $(0.0012)$ & $(0.0012)$ & $(0.0012)$ & $(0.0012)$ & $(0.0012)$ & $(0.0012)$ & $(0.0011)$ & $(0.0012)$ & $(0.0012)$ \\
\hline \multirow{2}{*}{ Rural dummy } & -0.0004 & -0.0002 & -0.0004 & -0.0004 & -0.0004 & -0.0004 & -0.0004 & $-6,396 \mathrm{e}-05$ & -0.0004 & -0.0003 \\
\hline & $(0.0011)$ & $(0.0011)$ & $(0.0011)$ & $(0.0011)$ & $(0.0011)$ & $(0.0011)$ & $(0.0011)$ & $(0.0011)$ & $(0.0011)$ & $(0.0011)$ \\
\hline \multirow{2}{*}{$\begin{array}{l}\text { Post-policy period } \\
\text { dummy }(t 2)\end{array}$} & $-0.0239 * *$ & $-0.0244 * *$ & $-0.0239 * *$ & $-0.0250^{* *}$ & $-0.0242 * *$ & $-0.0247^{* *}$ & $-0.0239 * *$ & $-0.0241 * *$ & $-0.02392 * *$ & $-0.0246^{* * *}$ \\
\hline & $(0.0011)$ & $(0.0010)$ & $(0.0011)$ & $(0.0010)$ & $(0.0011)$ & $(0.0010)$ & $(0.0011)$ & $(0.0009)$ & $(0.0011)$ & $(0.0010)$ \\
\hline \multirow{2}{*}{$\begin{array}{l}\text { Treatment group } \\
\text { dummy }(d T)\end{array}$} & 0.0013 & & 0.0013 & & 0.0012 & & 0.0013 & & 0.0013 & \\
\hline & $(0.0013)$ & & $(0.0013)$ & & $(0.0013)$ & & $(0.0013)$ & & $(0.0013)$ & \\
\hline \multirow{2}{*}{$\begin{array}{l}\text { Difference-in-difference } \\
\text { estimator }(t 2 \times d T)\end{array}$} & $-0.0037 * *$ & & $-0.0037 * *$ & & $-0.0029 *$ & & $-0.0037 * *$ & & $-0.0037 * *$ & \\
\hline & $(0.0017)$ & & $(0.0017)$ & & $(0.0017)$ & & $(0.0017)$ & & $(0.0017)$ & \\
\hline \multirow{2}{*}{$\begin{array}{l}\text { Treatment intensity } \\
\text { (Tint) }\end{array}$} & & $0.0340^{* *}$ & & -0.0072 & & 0.2739 & & $0.1118^{* *}$ & & 0.2688 \\
\hline & & $(0.0146)$ & & $(0.0320)$ & & $(0.2363)$ & & $(0.0272)$ & & $(0.1822)$ \\
\hline \multirow{2}{*}{$\begin{array}{l}\text { Post-policy period } \\
\text { dummy } * \text { Treatment } \\
\text { intensity }(t 2 \times \text { Tint })\end{array}$} & & $-0.0771 * *$ & & -0.0217 & & $-0.6246^{*}$ & & $-0.2259 * *$ & & $-0.5997 * *$ \\
\hline & & $(0.0196)$ & & $(0.0441)$ & & $(0.3219)$ & & $(0.0360)$ & & $(0.2421)$ \\
\hline $\mathrm{n}$ & 2502 & 2502 & 2502 & 2502 & 2502 & 2502 & 2502 & 2502 & 2502 & 2502 \\
\hline $\mathbf{R}^{2}$ & 0.4833 & 0.4854 & 0.4833 & 0.4824 & 0.4828 & 0.4830 & 0.4833 & 0.4903 & 0.4833 & 0.4835 \\
\hline
\end{tabular}

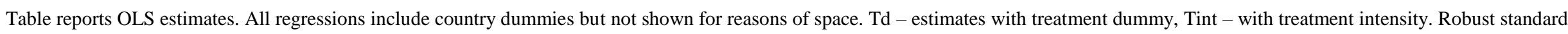
errors are reported in parentheses. * indicates significance at the 10 percent level, ** indicates significance at the 5 percent level 
Table D3. Estimations for 2007-2013 post-policy period

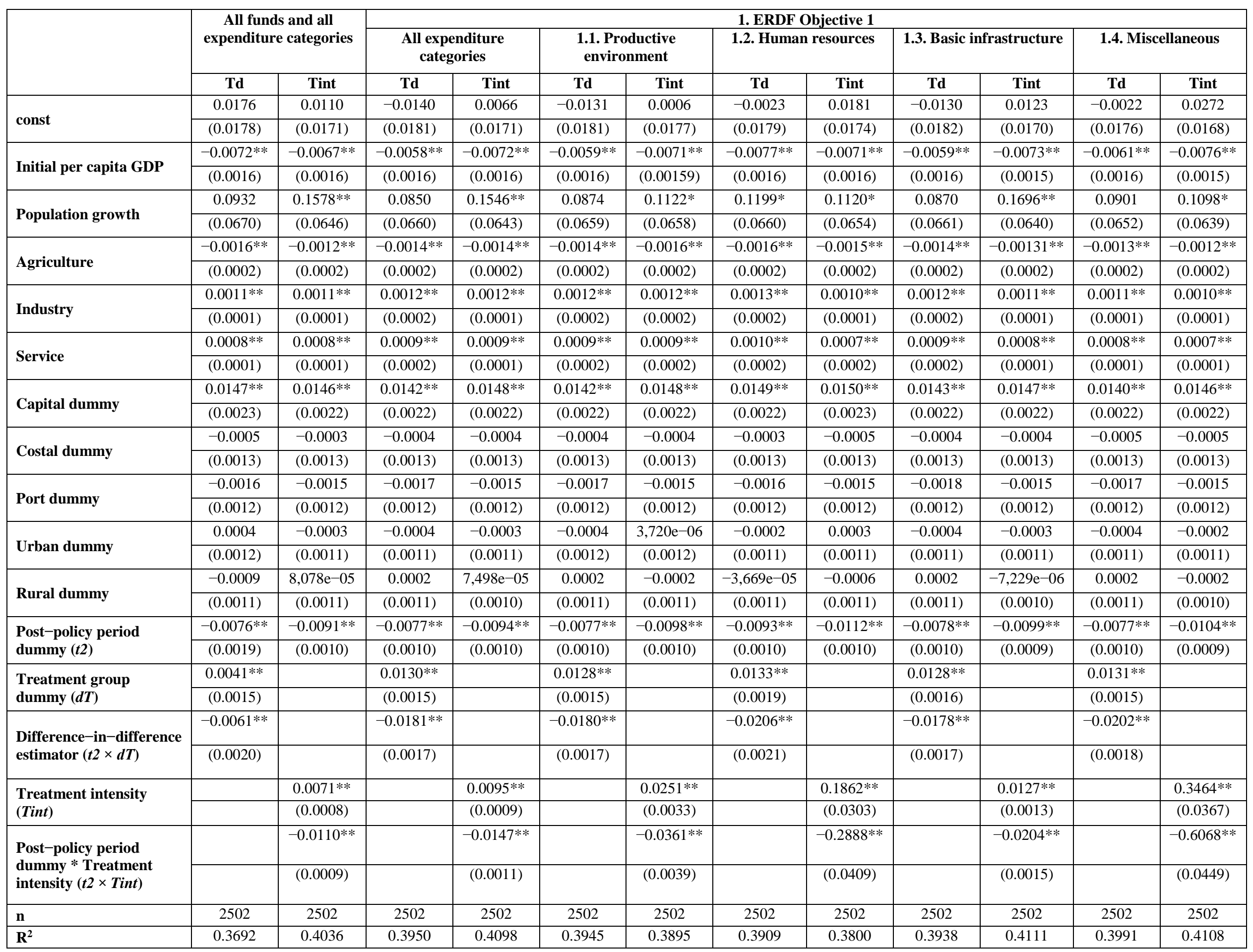

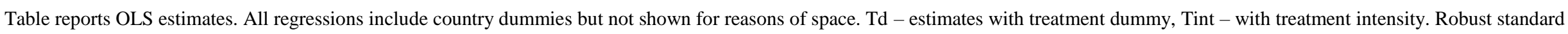
errors are reported in parentheses. * indicates significance at the 10 percent level, ** indicates significance at the 5 percent level 
Table D3. (continued)

\begin{tabular}{|c|c|c|c|c|c|c|c|c|c|c|c|c|}
\hline & \multirow{2}{*}{\multicolumn{2}{|c|}{$\begin{array}{c}\text { Productive } \\
\text { environment }(\text { all funds } \\
\text { ERDF+CF) }\end{array}$}} & \multicolumn{10}{|c|}{ 2. ERDF Objective 2} \\
\hline & & & \multicolumn{2}{|c|}{$\begin{array}{l}\text { All expenditure } \\
\text { categories }\end{array}$} & \multicolumn{2}{|c|}{$\begin{array}{l}\text { 2.1. Productive } \\
\text { environment }\end{array}$} & \multicolumn{2}{|c|}{ 2.2. Human resources } & \multicolumn{2}{|c|}{$\begin{array}{c}\text { 2.3. Basic } \\
\text { infrastructure }\end{array}$} & \multicolumn{2}{|c|}{ 2.4. Miscellaneous } \\
\hline & Td & Tint & Td & Tint & Td & Tint & Td & Tint & Td & Tint & Td & Tint \\
\hline \multirow{2}{*}{ const } & 0.0172 & 0.0054 & 0.0146 & 0.0198 & 0.0150 & 0.0210 & 0.0237 & 0.0237 & 0.0172 & 0.0205 & 0.0168 & 0.0222 \\
\hline & $(0.0178)$ & $(0.0178)$ & $(0.0174)$ & $(0.0174)$ & $(0.0174)$ & $(0.0174)$ & $(0.0175)$ & $(0.0174)$ & $(0.0174)$ & $(0.0175)$ & $(0.0175)$ & $(0.0174)$ \\
\hline \multirow{2}{*}{ Initial per capita GDP } & $-0.0072 * *$ & $-0.0073 * *$ & $-0.0065^{* *}$ & $-0.0069 * *$ & $-0.0066^{* *}$ & $-0.0071 * *$ & $-0.0070 * *$ & $-0.0071 * *$ & $-0.0067 * *$ & $-0.0069 * *$ & $-0.0068^{* *}$ & $-0.0070 * *$ \\
\hline & $(0.0016)$ & $(0.0016)$ & $(0.0016)$ & $(0.0016)$ & $(0.0016)$ & $(0.0016)$ & $(0.0016)$ & $(0.0016)$ & $(0.0016)$ & $(0.0016)$ & $(0.0016)$ & $(0.0016)$ \\
\hline \multirow{2}{*}{ Population growth } & 0.0925 & $0.1138^{*}$ & $0.1375^{* *}$ & $0.1402 * *$ & $0.1362 * *$ & $0.1382 * *$ & $0.1129^{*}$ & $0.1195^{*}$ & $0.1289^{*}$ & $0.1233^{*}$ & $0.1381 * *$ & $0.1291 *$ \\
\hline & $(0.0670)$ & $(0.0665)$ & $(0.0658)$ & $(0.0665)$ & $(0.0658)$ & $(0.0663)$ & $(0.0663)$ & $(0.0663)$ & $(0.0659)$ & $(0.0665)$ & $(0.0663)$ & $(0.0662)$ \\
\hline \multirow{2}{*}{ Agriculture } & $-0.0016^{* *}$ & $-0.0016^{* *}$ & $-0.0016^{* *}$ & $-0.0016 * *$ & $-0.0016^{* *}$ & $-0.0016^{* *}$ & $-0.0016^{* *}$ & $-0.0016 * *$ & $-0.0016^{* *}$ & $-0.0016^{* *}$ & $-0.0016^{* *}$ & $-0.0016^{* *}$ \\
\hline & $(0.0002)$ & $(0.0002)$ & $(0.0002)$ & $(0.0002)$ & $(0.0002)$ & $(0.0002)$ & $(0.0002)$ & $(0.0001)$ & $(0.0002)$ & $(0.0002)$ & $(0.0002)$ & $(0.0002)$ \\
\hline \multirow{2}{*}{ Industry } & $0.0010 * *$ & $0.0012 * *$ & $0.0010 * *$ & $0.0010 * *$ & $0.0010 * *$ & $0.0010 * *$ & $0.0010 * *$ & $0.0010 * *$ & $0.0010^{* *}$ & $0.0010 * *$ & $0.0010^{* *}$ & $0.0010 * *$ \\
\hline & $(0.0001)$ & $(0.0002)$ & $(0.0001)$ & $(0.0001)$ & $(0.0001)$ & $(0.0001)$ & $(0.0001)$ & $(0.0001)$ & $(0.0001)$ & $(0.0001)$ & $(0.0001)$ & $(0.0001)$ \\
\hline Service & $0.0008 * *$ & $0.0009 * *$ & $0.0008 * *$ & $0.0007 * *$ & $0.0008 * *$ & $0.0007 * *$ & $0.0007 * *$ & $0.0007 * *$ & $0.0007 * *$ & $0.0007 * *$ & $0.0008 * *$ & $0.0007 * *$ \\
\hline \multirow{2}{*}{ Capital dummy } & $0.0147 * *$ & $0.0148 * *$ & $0.0146 * *$ & $0.0145 * *$ & $0.0146 * *$ & $0.0146 * *$ & $0.0149 * *$ & $0.0147 * *$ & $0.0146^{* *}$ & $0.0147 * *$ & $0.0147 * *$ & $0.0145^{* *}$ \\
\hline & $(0.0023)$ & $(0.0022)$ & $(0.0023)$ & $(0.0023)$ & $(0.0023)$ & $(0.0023)$ & $(0.0023)$ & $(0.0023)$ & $(0.0023)$ & $(0.0023)$ & $(0.0023)$ & $(0.0023)$ \\
\hline \multirow{2}{*}{ Costal dummy } & -0.0005 & -0.0005 & -0.0005 & -0.0003 & -0.0005 & -0.0003 & -0.0005 & -0.0003 & -0.0005 & -0.0005 & -0.0005 & -0.0007 \\
\hline & $(0.0013)$ & $(0.0013)$ & $(0.0013)$ & $(0.0013)$ & $(0.0013)$ & $(0.0013)$ & $(0.0013)$ & $(0.0014)$ & $(0.0013)$ & $(0.0013)$ & $(0.0013)$ & $(0.0013)$ \\
\hline \multirow{2}{*}{ Port dummy } & -0.0016 & -0.0015 & -0.0015 & -0.0015 & -0.0015 & -0.0015 & -0.0014 & -0.0016 & -0.0015 & -0.0015 & -0.0014 & -0.0014 \\
\hline & $(0.0012)$ & $(0.0012)$ & $(0.0012)$ & $(0.0012)$ & $(0.0012)$ & $(0.0012)$ & $(0.0012)$ & $(0.0012)$ & $(0.0012)$ & $(0.0012)$ & $(0.0012)$ & $(0.0012)$ \\
\hline \multirow{2}{*}{ Urban dummy } & 0.0004 & $7,375 \mathrm{e}-05$ & $8,241 \mathrm{e}-05$ & 0.0002 & $8,950 \mathrm{e}-05$ & 0.0001 & 0.0005 & 0.0005 & 0.0002 & 0.0004 & 0.0003 & 0.0006 \\
\hline & $(0.0012)$ & $(0.0012)$ & $(0.0012)$ & $(0.0012)$ & $(0.0012)$ & $(0.0012)$ & $(0.0012)$ & $(0.0012)$ & $(0.0012)$ & $(0.0012)$ & $(0.0012)$ & $(0.0012)$ \\
\hline \multirow{2}{*}{ Rural dummy } & -0.0009 & -0.0004 & -0.0006 & -0.0006 & -0.0006 & -0.0005 & -0.0010 & -0.0009 & -0.0008 & -0.0009 & -0.0008 & -0.0007 \\
\hline & $(0.0011)$ & $(0.0011)$ & $(0.0011)$ & $(0.0011)$ & $(0.0011)$ & $(0.0011)$ & $(0.0011)$ & $(0.0011)$ & $(0.0011)$ & $(0.0011)$ & $(0.0011)$ & $(0.0011)$ \\
\hline \multirow{2}{*}{$\begin{array}{l}\text { Post-policy period } \\
\text { dummy }(t 2)\end{array}$} & $-0.0073 * *$ & $-0.0091 * *$ & $-0.0166 * *$ & $-0.0143 * *$ & $-0.0165 * *$ & $-0.0144 * *$ & $-0.0119 * *$ & $-0.0121 * *$ & $-0.0155^{* *}$ & $-0.0131 * *$ & $-0.0142 * *$ & $-0.0130 * *$ \\
\hline & $(0.0019)$ & $(0.0010)$ & $(0.0012)$ & $(0.0011)$ & $(0.0012)$ & $(0.0011)$ & $(0.0010)$ & $(0.0010)$ & $(0.0012)$ & $(0.0010)$ & $(0.0012)$ & $(0.0010)$ \\
\hline \multirow{2}{*}{$\begin{array}{l}\text { Treatment group } \\
\text { dummy }(d T)\end{array}$} & $0.0044 * *$ & & $-0.0060 * *$ & & $-0.0058 * *$ & & 0.0003 & & $-0.0039 * *$ & & $-0.0043^{* *}$ & \\
\hline & $(0.0015)$ & & $(0.0013)$ & & $(0.0013)$ & & $(0.0018)$ & & $(0.0013)$ & & $(0.0013)$ & \\
\hline \multirow{2}{*}{$\begin{array}{l}\text { Treatment intensity } \\
\text { (Tint) }\end{array}$} & & $0.0217 * *$ & & $-0.0425^{* *}$ & & $-0.0690 * *$ & & -0.0714 & & $-0.0441^{*}$ & & $-0.7307 * *$ \\
\hline & & $(0.0033)$ & & $(0.0100)$ & & $(0.0144)$ & & $(0.2124)$ & & $(0.0250)$ & & $(0.2402)$ \\
\hline \multirow{2}{*}{$\begin{array}{l}\text { Post-policy period } \\
\text { dummy } * \text { Treatment } \\
\text { intensity }(t 2 \times \text { Tint })\end{array}$} & & $-0.0331 * *$ & & $0.0508 * *$ & & $0.0841 * *$ & & -0.3321 & & $0.0579 *$ & & $0.6770 * *$ \\
\hline & & $(0.0039)$ & & $(0.01350)$ & & $(0.01928)$ & & $(0.2738)$ & & $(0.0337)$ & & $(0.3298)$ \\
\hline n & 2502 & 2502 & 2502 & 2502 & 2502 & 2502 & 2502 & 2502 & 2502 & 2502 & 2502 & 2502 \\
\hline $\mathbf{R}^{2}$ & 0.3695 & 0.3852 & 0.3748 & 0.3716 & 0.3743 & 0.3731 & 0.3674 & 0.3676 & 0.3716 & 0.3676 & 0.3694 & 0.3690 \\
\hline
\end{tabular}

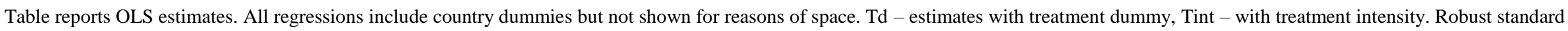
errors are reported in parentheses. * indicates significance at the 10 percent level, $* *$ indicates significance at the 5 percent level 
Table D3. (continued)

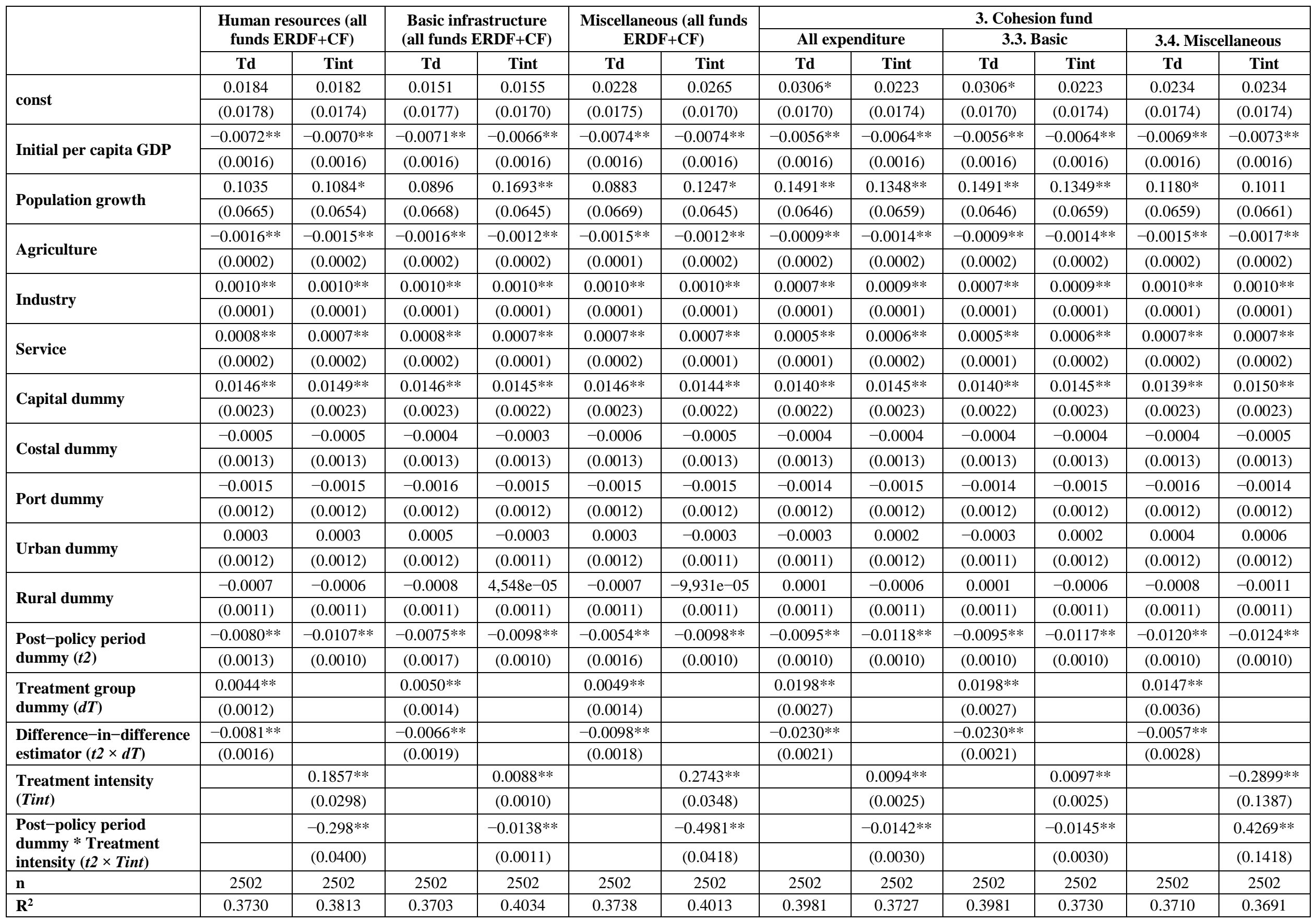

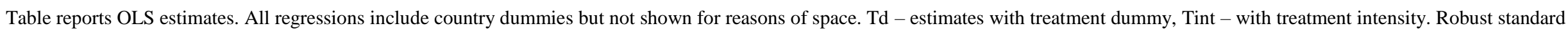
errors are reported in parentheses. * indicates significance at the 10 percent level, $* *$ indicates significance at the 5 percent level 
Table D3. (continued)

\begin{tabular}{|c|c|c|c|c|c|c|c|c|c|c|}
\hline & \multicolumn{10}{|c|}{ 4. ERDF Urban } \\
\hline & \multicolumn{2}{|c|}{$\begin{array}{l}\text { All expenditure } \\
\text { categories }\end{array}$} & \multicolumn{2}{|c|}{$\begin{array}{l}\text { 4.1. Productive } \\
\text { environment }\end{array}$} & \multicolumn{2}{|c|}{ 4.2. Human resources } & \multicolumn{2}{|c|}{ 4.3. Basic infrastructure } & \multicolumn{2}{|c|}{ 4.4. Miscellaneous } \\
\hline & Td & Tint & Td & Tint & Td & Tint & Td & Tint & Td & Tint \\
\hline \multirow{2}{*}{ const } & 0.0220 & 0.02143 & 0.0223 & 0.0219 & 0.0220 & 0.0222 & 0.0221 & 0.0216 & 0.0223 & 0.0213 \\
\hline & $(0.0174)$ & $(0.0174)$ & $(0.0174)$ & $(0.0174)$ & $(0.0174)$ & $(0.0174)$ & $(0.0174)$ & $(0.0174)$ & $(0.0174)$ & $(0.0174)$ \\
\hline \multirow{2}{*}{ Initial per capita GDP } & $-0.0070^{* *}$ & $-0.0072 * *$ & $-0.0071 * *$ & $-0.0071 * *$ & $-0.0070 * *$ & $-0.0071 * *$ & $-0.0071 * *$ & $-0.0072 * *$ & $-0.0071 * *$ & $-0.0072 * *$ \\
\hline & $\begin{array}{l}(0.0016) \\
\end{array}$ & $\begin{array}{l}(0.0016) \\
\end{array}$ & $\begin{array}{l}(0.0016) \\
\end{array}$ & $\begin{array}{l}(0.0016) \\
\end{array}$ & $\begin{array}{l}(0.0016) \\
\end{array}$ & $\begin{array}{l}(0.0016) \\
\end{array}$ & (0.0016) & $\begin{array}{l}(0.0016) \\
\end{array}$ & $\begin{array}{l}(0.0016) \\
\end{array}$ & (0.0016) \\
\hline \multirow{2}{*}{ Population growth } & 0.0972 & 0.1030 & 0.0987 & 0.1077 & 0.0985 & 0.1045 & 0.0963 & 0.1061 & 0.0994 & 0.1012 \\
\hline & $(0.0664)$ & $(0.0663)$ & $(0.0665)$ & $(0.0663)$ & $(0.0664)$ & $(0.0664)$ & $(0.0664)$ & $(0.0662)$ & $(0.0665)$ & $(0.0663)$ \\
\hline \multirow{2}{*}{ Agriculture } & $-0.0016^{* *}$ & $-0.0016^{* *}$ & $-0.0016^{* *}$ & $-0.0016^{* *}$ & $-0.0016^{* *}$ & $-0.0016^{* *}$ & $-0.00162 * *$ & $-0.0016^{* *}$ & $-0.0016^{* *}$ & $-0.0016^{* *}$ \\
\hline & $(0.0002)$ & $(0.0002)$ & $(0.0002)$ & $(0.0002)$ & $(0.0002)$ & $(0.0002)$ & $(0.0002)$ & $(0.0002)$ & $(0.0002)$ & $(0.0002)$ \\
\hline \multirow{2}{*}{ Industry } & $0.0010^{* *}$ & $0.0010^{* *}$ & $0.0010^{* *}$ & $0.0010^{* *}$ & $0.0010^{* * *}$ & $0.0010^{* *}$ & $0.0010^{* *}$ & $0.0010^{* *}$ & $0.0010^{* *}$ & $0.0010 * *$ \\
\hline & $(0.0001)$ & $(0.0001)$ & $(0.0001)$ & $(0.0001)$ & $(0.0001)$ & $(0.0001)$ & $(0.0001)$ & $(0.0001)$ & $(0.0001)$ & $(0.0001)$ \\
\hline \multirow{2}{*}{ Service } & $0.0007 * *$ & $0.0007 * *$ & $0.0007 * *$ & $0.0007^{* *}$ & $0.0007 * *$ & $0.0007 * *$ & $0.0007^{* *}$ & $0.0007 * *$ & $0.0007^{* *}$ & $0.0007 * *$ \\
\hline & $(0.0002)$ & $(0.0002)$ & $(0.0002)$ & $(0.0002)$ & $(0.0002)$ & $(0.0002)$ & $(0.0002)$ & $(0.0002)$ & $(0.0002)$ & $(0.0002)$ \\
\hline \multirow{2}{*}{ Capital dummy } & $0.0147 * *$ & $0.0148 * *$ & $0.0146 * *$ & $0.0148^{* *}$ & $0.0147 * *$ & $0.0148^{* *}$ & $0.0147^{* * *}$ & $0.0148^{* *}$ & $0.0147 * *$ & $0.0148 * *$ \\
\hline & $(0.0023)$ & $(0.0023)$ & $(0.0023)$ & $(0.0023)$ & $(0.0023)$ & $(0.0023)$ & $(0.0023)$ & $(0.0023)$ & $(0.0023)$ & $(0.0023)$ \\
\hline \multirow{2}{*}{ Costal dummy } & -0.0005 & -0.0005 & -0.0005 & -0.0006 & -0.0005 & -0.0005 & -0.0005 & -0.0005 & -0.0005 & -0.0005 \\
\hline & $(0.0013)$ & $(0.0013)$ & $(0.0013)$ & $(0.0013)$ & $(0.0013)$ & $(0.0013)$ & $(0.0013)$ & $(0.0013)$ & $(0.0013)$ & $(0.0013)$ \\
\hline \multirow{2}{*}{ Port dummy } & -0.0015 & -0.0015 & -0.0015 & -0.0015 & -0.0015 & -0.0015 & -0.0015 & -0.0015 & -0.0015 & -0.0015 \\
\hline & $(0.0012)$ & $(0.0012)$ & $(0.0012)$ & $(0.0012)$ & $(0.0012)$ & $(0.0012)$ & $(0.0012)$ & $(0.0012)$ & $(0.0012)$ & $(0.0012)$ \\
\hline \multirow{2}{*}{ Urban dummy } & 0.0004 & 0.0004 & 0.0004 & 0.0004 & 0.0004 & 0.0004 & 0.0004 & 0.0004 & 0.0004 & 0.0004 \\
\hline & $(0.0012)$ & $(0.0012)$ & $(0.0012)$ & $(0.0012)$ & $(0.0012)$ & $(0.0012)$ & $(0.0012)$ & $(0.0012)$ & $(0.0012)$ & $(0.0012)$ \\
\hline \multirow{2}{*}{ Rural dummy } & -0.0010 & -0.0009 & -0.0009 & -0.0009 & -0.0010 & -0.0009 & -0.0009 & -0.0009 & -0.0010 & -0.0009 \\
\hline & $(0.0011)$ & $(0.0011)$ & $(0.0011)$ & $(0.0011)$ & $(0.0011)$ & $(0.0011)$ & $(0.0011)$ & $(0.0011)$ & $(0.0011)$ & $(0.0011)$ \\
\hline \multirow{2}{*}{$\begin{array}{l}\text { Post-policy period } \\
\text { dummy }(t 2)\end{array}$} & $-0.0118^{* *}$ & $-0.0121^{* *}$ & $-0.0119^{* *}$ & $-0.0124 * *$ & $-0.0119 * *$ & $-0.0122 * *$ & $-0.0118^{* *}$ & $-0.0122^{* *}$ & $-0.0119 * *$ & $-0.0121^{* *}$ \\
\hline & $(0.0010)$ & $(0.0010)$ & $(0.0010)$ & $(0.0010)$ & $(0.0010)$ & $(0.0010)$ & $\begin{array}{l}(0.0010) \\
\end{array}$ & $(0.0010)$ & $(0.0010)$ & $(0.0010)$ \\
\hline \multirow{2}{*}{$\begin{array}{l}\text { Treatment group } \\
\text { dummy }(d T)\end{array}$} & $0.0042 *$ & & $0.0048^{*}$ & & $0.0047^{*}$ & & $0.0050^{* *}$ & & $0.0044 *$ & \\
\hline & $(0.0024)$ & & $(0.0026)$ & & $(0.0025)$ & & $(0.0024)$ & & $(0.0025)$ & \\
\hline \multirow{2}{*}{$\begin{array}{l}\text { Difference-in-difference } \\
\text { estimator }(t 2 \times d T)\end{array}$} & $-0.0086^{* *}$ & & $-0.0079 * *$ & & $-0.0090^{* *}$ & & $-0.0093^{* *}$ & & $-0.0088^{* *}$ & \\
\hline & $(0.0033)$ & & $(0.0036)$ & & $(0.0035)$ & & $(0.0034)$ & & $(0.0034)$ & \\
\hline \multirow{2}{*}{$\begin{array}{l}\text { Treatment intensity } \\
\text { (Tint) }\end{array}$} & & $0.1847^{* *}$ & & 0.4745 & & 1,0130 & & $0.2517 * *$ & & $3,0600 * *$ \\
\hline & & $(0.0857)$ & & $(0.4173)$ & & $(0.6370)$ & & $(0.1169)$ & & $(1,4100)$ \\
\hline \multirow{2}{*}{$\begin{array}{l}\text { Post-policy period } \\
\text { dummy } * \text { Treatment } \\
\text { intensity }(t 2 \times \text { Tint })\end{array}$} & & $-0.2708^{* *}$ & & -0.0856 & & -0.9709 & & $-0.4354^{* *}$ & & $-4,3670^{* *}$ \\
\hline & & $(0.1204)$ & & $(0.5867)$ & & $(0.8945)$ & & $(0.1644)$ & & $(1,9820)$ \\
\hline $\mathbf{n}$ & 2502 & 2502 & 2502 & 2502 & 2502 & 2502 & 2502 & 2502 & 2502 & 2502 \\
\hline $\mathbf{R}^{2}$ & 0.3684 & 0.3681 & 0.3679 & 0.3672 & 0.3683 & 0.3673 & 0.3686 & 0.3685 & 0.3683 & 0.3681 \\
\hline
\end{tabular}

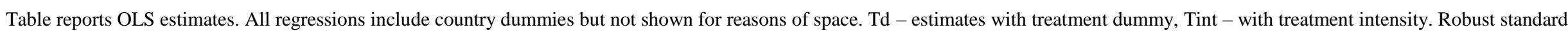
errors are reported in parentheses. * indicates significance at the 10 percent level, ** indicates significance at the 5 percent level 
Table D3. (continued)

\begin{tabular}{|c|c|c|c|c|c|c|c|c|c|c|}
\hline & \multicolumn{10}{|c|}{ 5. ERDF INTERREG IIIA } \\
\hline & \multicolumn{2}{|c|}{$\begin{array}{l}\text { All expenditure } \\
\text { categories }\end{array}$} & \multicolumn{2}{|c|}{$\begin{array}{l}\text { 5.1. Productive } \\
\text { environment }\end{array}$} & \multicolumn{2}{|c|}{ 5.2. Human resources } & \multicolumn{2}{|c|}{ 5.3. Basic infrastructure } & \multicolumn{2}{|c|}{ 5.4. Miscellaneous } \\
\hline & Td & Tint & Td & Tint & Td & Tint & Td & Tint & Td & Tint \\
\hline \multirow{2}{*}{ const } & 0.0226 & 0.0235 & 0.0226 & 0.0232 & 0.0225 & 0.0224 & 0.0226 & 0.0228 & 0.0226 & 0.0248 \\
\hline & $(0.0174)$ & $(0.0174)$ & $(0.0174)$ & $(0.0175)$ & $(0.0175)$ & $(0.0175)$ & $(0.0174)$ & $(0.017)$ & $(0.0174)$ & $(0.0174)$ \\
\hline \multirow{2}{*}{ Initial per capita GDP } & $-0.0071^{* *}$ & $-0.0073^{* *}$ & $-0.0071^{* *}$ & $-0.0071 * *$ & $-0.0071 * *$ & $-0.0071 * *$ & $-0.0071 * *$ & $-0.0074 * *$ & $-0.0071 * *$ & $-0.0071^{* *}$ \\
\hline & $(0.0016)$ & $(0.0016)$ & $(0.0016)$ & $(0.0016)$ & $(0.0016)$ & $(0.0016)$ & $(0.0016)$ & $(0.0016)$ & $(0.0016)$ & $(0.0016)$ \\
\hline \multirow{2}{*}{ Population growth } & $0.1172^{*}$ & $0.1291 * *$ & $0.1172 *$ & $0.1185^{*}$ & $0.1158 *$ & $0.1209^{*}$ & $0.1172 *$ & $0.1376^{\text {** }}$ & $0.1172 *$ & $0.1192 *$ \\
\hline & $(0.0661)$ & $(0.0659)$ & $(0.0661)$ & $(0.0661)$ & $(0.0661)$ & $(0.0661)$ & $(0.0661)$ & $(0.0655)$ & $(0.0661)$ & $(0.0659)$ \\
\hline \multirow{2}{*}{ Agriculture } & $-0.0016^{* *}$ & $-0.0015^{* *}$ & $-0.0016^{* *}$ & $-0.0016^{* *}$ & $-0.0016^{* *}$ & $-0.0016^{* *}$ & $-0.0016^{* *}$ & $-0.00144 * *$ & $-0.0016^{* *}$ & $-0.0015 * *$ \\
\hline & $(0.0002)$ & $(0.0002)$ & $(0.0002)$ & $(0.0002)$ & $(0.0002)$ & $(0.0002)$ & $(0.0002)$ & $(0.0002)$ & $(0.0002)$ & $(0.0002)$ \\
\hline \multirow{2}{*}{ Industry } & $0.0010^{* *}$ & $0.0010 * *$ & $0.0010 * *$ & $0.0010 * *$ & $0.0010^{* *}$ & $0.0010 * *$ & $0.0010 * *$ & $0.0010^{* *}$ & $0.0010 * *$ & $0.0010^{* *}$ \\
\hline & $(0.0001)$ & $(0.0001)$ & $(0.0001)$ & $(0.0001)$ & $(0.0001)$ & $(0.0001)$ & $(0.0001)$ & $\begin{array}{l}(0.0001) \\
\end{array}$ & $(0.0001)$ & $(0.0001)$ \\
\hline \multirow{2}{*}{ Service } & $0.0007 * *$ & $0.0007 * *$ & $0.0007 * *$ & $0.0007 * *$ & $0.0007 * *$ & $0.0007 * *$ & $0.0007 * *$ & $0.0007^{* *}$ & $0.0007 * *$ & $0.0007 * *$ \\
\hline & $(0.0002)$ & $(0.0002)$ & $(0.0002)$ & $(0.0002)$ & $(0.0002)$ & $(0.0002)$ & $(0.0002)$ & $(0.0001)$ & $(0.0002)$ & $(0.0002)$ \\
\hline \multirow{2}{*}{ Capital dummy } & $0.0148 * *$ & $0.0145 * *$ & $0.0148 * *$ & $0.0147 * *$ & $0.0148 * *$ & $0.0147 * *$ & $0.0148 * *$ & $0.0145^{* *}$ & $0.0148 * *$ & $0.0146^{* *}$ \\
\hline & $(0.0023)$ & $(0.0023)$ & $(0.0023)$ & $(0.0023)$ & $(0.0023)$ & $(0.0023)$ & $(0.0023)$ & $(0.0023)$ & $(0.0023)$ & $(0.0023)$ \\
\hline \multirow{2}{*}{ Costal dummy } & -0.0005 & -0.0005 & -0.0005 & -0.0005 & -0.0005 & -0.0005 & -0.0005 & -0.0005 & -0.0005 & -0.0005 \\
\hline & $(0.0013)$ & $(0.0013)$ & $(0.0013)$ & $(0.0013)$ & $(0.0013)$ & $(0.0013)$ & $(0.0013)$ & $(0.0013)$ & $(0.0013)$ & $(0.0013)$ \\
\hline \multirow{2}{*}{ Port dummy } & -0.0015 & -0.0015 & -0.0014 & -0.0014 & -0.0015 & -0.0014 & -0.0015 & -0.0015 & -0.0015 & -0.0014 \\
\hline & $(0.0012)$ & $(0.0012)$ & $(0.0012)$ & $(0.0012)$ & $(0.0012)$ & $(0.0012)$ & $(0.0012)$ & $(0.0012)$ & $(0.0012)$ & $(0.0012)$ \\
\hline \multirow{2}{*}{ Urban dummy } & 0.0003 & 0.0001 & 0.0004 & 0.0003 & 0.0004 & 0.0003 & 0.0004 & $-1,087 \mathrm{e}-05$ & 0.0004 & 0.0003 \\
\hline & $(0.0012)$ & $(0.0012)$ & $(0.0012)$ & $(0.0012)$ & $(0.0012)$ & $(0.0012)$ & $(0.0012)$ & $(0.0012)$ & $(0.0012)$ & $(0.0012)$ \\
\hline \multirow{2}{*}{ Rural dummy } & -0.0009 & -0.0007 & -0.0009 & -0.0009 & -0.0009 & -0.0009 & -0.0009 & -0.0005 & -0.0009 & -0.0008 \\
\hline & $(0.0011)$ & $(0.0011)$ & $(0.0011)$ & $(0.0011)$ & $(0.0011)$ & $(0.0011)$ & $(0.0011)$ & $(0.0011)$ & $(0.0011)$ & $(0.0011)$ \\
\hline \multirow{2}{*}{$\begin{array}{l}\text { Post-policy period } \\
\text { dummy }(t 2)\end{array}$} & $-0.0118^{* *}$ & $-0.0115^{* *}$ & $-0.0118^{* *}$ & $-0.0122 * *$ & $-0.0121 * *$ & $-0.0118^{* *}$ & $-0.0118^{* *}$ & $-0.0113^{* *}$ & $-0.0118 * *$ & $-0.0117^{* *}$ \\
\hline & $(0.0011)$ & $(0.0010)$ & $(0.0011)$ & $(0.0010)$ & $(0.0011)$ & $(0.0010)$ & $(0.0011)$ & $(0.0010)$ & $(0.0011)$ & $(0.0010)$ \\
\hline \multirow{2}{*}{$\begin{array}{l}\text { Treatment group } \\
\text { dummy }(d T)\end{array}$} & 0.0009 & & 0.0009 & & 0.0007 & & 0.0009 & & 0.0009 & \\
\hline & $(0.0013)$ & & $(0.0013)$ & & $(0.0013)$ & & $(0.0013)$ & & $(0.0013)$ & \\
\hline \multirow{2}{*}{$\begin{array}{l}\text { Difference-in-difference } \\
\text { estimator }(t 2 \times d T)\end{array}$} & -0.0019 & & -0.0019 & & -0.0011 & & -0.0019 & & -0.0019 & \\
\hline & $(0.0017)$ & & (0.0017) & & (0.0017) & & (0.0017) & & $(0.0017)$ & \\
\hline \multirow{2}{*}{$\begin{array}{l}\text { Treatment intensity } \\
\text { (Tint) }\end{array}$} & & $0.0448^{* *}$ & & 0.0123 & & 0.3705 & & $0.1304^{* *}$ & & $0.4091 * *$ \\
\hline & & $(0.0148)$ & & $(0.0328)$ & & $(0.2399)$ & & $(0.0275)$ & & $(0.1847)$ \\
\hline \multirow{2}{*}{$\begin{array}{l}\text { Post-policy period } \\
\text { dummy } * \text { Treatment } \\
\text { intensity }(t 2 \times \text { Tint })\end{array}$} & & $-0.1038^{* *}$ & & -0.0609 & & $-0.8494 * *$ & & $-0.2795^{* *}$ & & $-0.9467 * *$ \\
\hline & & $(0.0199)$ & & $(0.0448)$ & & $(0.3267)$ & & $(0.0365)$ & & $(0.2454)$ \\
\hline $\mathbf{n}$ & 2502 & 2502 & 2502 & 2502 & 2502 & 2502 & 2502 & 2502 & 2502 & 2502 \\
\hline $\mathbf{R}^{2}$ & 0.3670 & 0.3737 & 0.3670 & 0.3673 & 0.3667 & 0.3684 & 0.3670 & 0.3815 & 0.3670 & 0.3705 \\
\hline
\end{tabular}

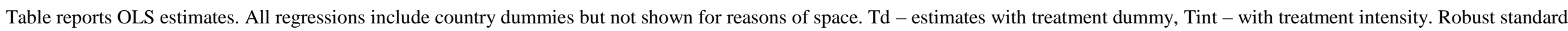
errors are reported in parentheses. * indicates significance at the 10 percent level, ** indicates significance at the 5 percent level 
Table D4. Estimations for 2007-2014 post-policy period

\begin{tabular}{|c|c|c|c|c|c|c|c|c|c|c|c|c|}
\hline & \multirow{2}{*}{\multicolumn{2}{|c|}{$\begin{array}{l}\text { All funds and all } \\
\text { expenditure categories }\end{array}$}} & \multicolumn{10}{|c|}{ 1. ERDF Objective 1} \\
\hline & & & \multicolumn{2}{|c|}{$\begin{array}{c}\text { All expenditure } \\
\text { categories }\end{array}$} & \multicolumn{2}{|c|}{$\begin{array}{c}\text { 1.1. Productive } \\
\text { environment }\end{array}$} & \multicolumn{2}{|c|}{ 1.2. Human resources } & \multicolumn{2}{|c|}{$\begin{array}{c}\text { 1.3. Basic } \\
\text { infrastructure }\end{array}$} & \multicolumn{2}{|c|}{ 1.4. Miscellaneous } \\
\hline & Td & Tint & Td & Tint & Td & Tint & Td & Tint & Td & Tint & Td & Tint \\
\hline \multirow{2}{*}{ const } & $0.0280 *$ & 0.0216 & 0.0025 & 0.0180 & 0.0031 & 0.0132 & 0.0139 & $0.0283 *$ & 0.0042 & 0.0228 & 0.0107 & $0.0359 * *$ \\
\hline & $(0.0162)$ & $(0.0156)$ & $(0.0166)$ & $(0.0156)$ & $(0.0166)$ & $(0.0161)$ & $(0.0164)$ & $(0.0159)$ & $(0.0166)$ & $(0.0155)$ & $(0.0160)$ & $(0.0154)$ \\
\hline \multirow{2}{*}{ Initial per capita GDP } & $-0.0042 * *$ & $-0.0041^{* *}$ & $-0.0033 * *$ & $-0.0046^{* *}$ & $-0.0033^{* *}$ & $-0.0043^{* *}$ & $-0.0047 * *$ & $-0.0041^{* *}$ & $-0.0034 * *$ & $-0.0045^{* *}$ & $-0.0034 * *$ & $-0.0048 * *$ \\
\hline & $(0.0015)$ & $(0.0014)$ & $(0.0014)$ & $(0.0014)$ & $(0.0014)$ & $(0.0014)$ & $(0.0014)$ & $(0.0014)$ & $(0.0014)$ & $(0.00141)$ & $(0.0014)$ & $(0.0014)$ \\
\hline \multirow{2}{*}{ Population growth } & 0.0175 & 0.0581 & 0.0034 & 0.0564 & 0.0021 & 0.0129 & 0.0082 & 0.0014 & 0.0007 & 0.0677 & 0.0050 & 0.0059 \\
\hline & $(0.0608)$ & $(0.0589)$ & $(0.0602)$ & $(0.0586)$ & $(0.0601)$ & $(0.0597)$ & $(0.0605)$ & $(0.0595)$ & $(0.0603)$ & $(0.0584)$ & $(0.0594)$ & $(0.0583)$ \\
\hline \multirow{2}{*}{ Agriculture } & $-0.0009 * *$ & $-0.0006^{* *}$ & $-0.0008 * *$ & $-0.0007 * *$ & $-0.0008 * *$ & $-0.0009 * *$ & $-0.0009 * *$ & $-0.0008 * *$ & $-0.0008 * *$ & $-0.0006 * *$ & $-0.0007 * *$ & $-0.0006^{* *}$ \\
\hline & $(0.0002)$ & $(0.0002)$ & $(0.0002)$ & $(0.0002)$ & $(0.0002)$ & $(0.0002)$ & $(0.0002)$ & $(0.0002)$ & $(0.0002)$ & $(0.0002)$ & $(0.0002)$ & $(0.0002)$ \\
\hline \multirow{2}{*}{ Industry } & $0.0005^{* *}$ & $0.0005^{* *}$ & $0.0006^{* *}$ & $0.0006^{* *}$ & $0.0006^{* *}$ & $0.0007 * *$ & $0.0007^{* *} *$ & $0.0005^{* *}$ & $0.0006^{* *}$ & $0.0006^{* *}$ & $0.0006^{* * *}$ & $0.0005^{* *}$ \\
\hline & $(0.0001)$ & $(0.0001)$ & $(0.0001)$ & $(0.0001)$ & $(0.0001)$ & $(0.0001)$ & $(0.0001)$ & $(0.0001)$ & $(0.0001)$ & $(0.0001)$ & $(0.0001)$ & $(0.0001)$ \\
\hline \multirow{2}{*}{ Service } & $0.0003 * *$ & $0.0004^{* *}$ & $0.0005^{* *}$ & $0.0005^{* *}$ & $0.0005^{* *}$ & $0.0005^{* *}$ & $0.0006 * *$ & $0.0003 * *$ & $0.0005^{* *}$ & $0.0004 * *$ & $0.0004 * *$ & $0.0003 * *$ \\
\hline & $(0.0001)$ & $(0.0001)$ & $(0.0001)$ & $(0.0001)$ & $(0.0001)$ & $(0.0001)$ & $(0.0001)$ & $(0.0001)$ & $(0.0001)$ & $(0.0001)$ & $(0.0001)$ & $(0.0001)$ \\
\hline \multirow{2}{*}{ Capital dummy } & $0.0110 * *$ & $0.0109 * *$ & $0.0106^{* *}$ & $0.0111 * *$ & $0.0106^{* *}$ & $0.0111 * *$ & $0.0112 * *$ & $0.0112 * *$ & $0.0107 * *$ & $0.0110 * *$ & $0.0104 * *$ & $0.0110 * *$ \\
\hline & $(0.0021)$ & $(0.0020)$ & $(0.0020)$ & $(0.0020)$ & $(0.0020)$ & $(0.0020)$ & $(0.0020)$ & $(0.0021)$ & $(0.0020)$ & $(0.0020)$ & $(0.0020)$ & $(0.0020)$ \\
\hline \multirow{2}{*}{ Costal dummy } & 0.0002 & 0.0003 & 0.0003 & 0.0003 & 0.0003 & 0.0003 & 0.0004 & 0.0002 & 0.0003 & 0.0003 & 0.0002 & 0.0002 \\
\hline & $(0.0012)$ & $(0.0012)$ & $(0.0012)$ & $(0.0012)$ & $(0.0012)$ & $(0.0012)$ & $(0.0012)$ & $(0.0012)$ & $(0.0012)$ & $(0.0012)$ & $(0.0012)$ & $(0.0012)$ \\
\hline \multirow{2}{*}{ Port dummy } & $-0.0024 * *$ & $-0.0024 * *$ & $-0.0025^{* *}$ & $-0.0024 * *$ & $-0.0025^{* *}$ & $-0.0024 * *$ & $-0.0024 * *$ & $-0.0023^{* *}$ & $-0.0025^{* *}$ & $-0.0024 * *$ & $-0.0025^{* *}$ & $-0.0023 * *$ \\
\hline & $(0.0011)$ & $(0.0011)$ & $(0.0011)$ & $(0.0011)$ & $(0.0011)$ & $(0.0011)$ & $(0.0011)$ & $(0.0011)$ & $(0.0011)$ & $(0.0011)$ & $(0.0011)$ & $(0.0011)$ \\
\hline \multirow{2}{*}{ Urban dummy } & 0.0008 & 0.0001 & 0.0001 & 0.0001 & 0.0001 & 0.0004 & 0.0004 & 0.0007 & 0.0001 & 0.0002 & 0.0001 & 0.0003 \\
\hline & $(0.0011)$ & $(0.0010)$ & $(0.0010)$ & $(0.0010)$ & $(0.0010)$ & $(0.0010)$ & $(0.0011)$ & $(0.0011)$ & $(0.0010)$ & $(0.0010)$ & $(0.0010)$ & $(0.0010)$ \\
\hline \multirow{2}{*}{ Rural dummy } & -0.0002 & 0.0006 & 0.0007 & 0.0006 & 0.0007 & 0.0005 & 0.0004 & $4,159 e^{-}-05$ & 0.0007 & 0.0006 & 0.0007 & 0.0004 \\
\hline & $(0.0010)$ & $(0.0010)$ & $(0.0010)$ & $(0.0010)$ & $(0.0010)$ & $(0.0010)$ & $(0.0010)$ & $(0.0010)$ & $(0.0010)$ & $(0.0010)$ & $(0.0010)$ & $(0.0010)$ \\
\hline \multirow{2}{*}{$\begin{array}{l}\text { Post-policy period } \\
\text { dummy }(t 2)\end{array}$} & $-0.0117 * *$ & $-0.0133 * *$ & $-0.0123 * *$ & $-0.0136 * *$ & $-0.0124 * *$ & $-0.0138 * *$ & $-0.0142 * *$ & $-0.0153 * *$ & $-0.0125^{* *}$ & $-0.0140 * *$ & $-0.0123 * *$ & $-0.0145^{* *}$ \\
\hline & $(0.0017)$ & $(0.0009)$ & $(0.0010)$ & $(0.0009)$ & $(0.00010)$ & $(0.0009)$ & $(0.0009)$ & $(0.0009)$ & $(0.0009)$ & $(0.0009)$ & $(0.0009)$ & $(0.0008)$ \\
\hline \multirow{2}{*}{$\begin{array}{l}\text { Treatment group } \\
\text { dummy }(d T)\end{array}$} & $0.0037 * *$ & & $0.0103 * *$ & & $0.0101 * *$ & & $0.0090 * *$ & & $0.0098 * *$ & & $0.0107 * *$ & \\
\hline & $(0.0014)$ & & $(0.0014)$ & & $(0.0014)$ & & $(0.0017)$ & & $(0.0014)$ & & $(0.0014)$ & \\
\hline \multirow{2}{*}{$\begin{array}{l}\text { Difference-in-difference } \\
\text { estimator }(t 2 \times d T)\end{array}$} & $-0.0058 * *$ & & $-0.0150^{* *}$ & & $-0.0149^{* *}$ & & $-0.0142 * *$ & & $-0.0146^{* *}$ & & $-0.0172 * *$ & \\
\hline & $(0.0018)$ & & $(0.0016)$ & & $(0.0016)$ & & $(0.0019)$ & & $(0.0016)$ & & $(0.0016)$ & \\
\hline \multirow{2}{*}{$\begin{array}{l}\text { Treatment intensity } \\
\text { (Tint) }\end{array}$} & & $0.0058^{* *}$ & & $0.0079 * *$ & & $0.0216^{* *}$ & & $0.1480^{* *}$ & & $0.0104 * *$ & & $0.2916^{* *}$ \\
\hline & & $(0.0007)$ & & $(0.0009)$ & & $(0.0030)$ & & $(0.0276)$ & & $(0.0011)$ & & $(0.0335)$ \\
\hline \multirow{2}{*}{$\begin{array}{l}\text { Post-policy period } \\
\text { dummy } * \text { Treatment } \\
\text { intensity }(t 2 \times \text { Tint })\end{array}$} & & $-0.0096^{* *}$ & & $-0.0130^{* *}$ & & $-0.0338^{* *}$ & & $-0.2349 * *$ & & $-0.0177 * *$ & & $-0.4940^{* *}$ \\
\hline & & $(0.0008)$ & & $(0.0010)$ & & $(0.0036)$ & & $(0.0372)$ & & $(0.0014)$ & & $(0.0410)$ \\
\hline n & 2502 & 2502 & 2502 & 2502 & 2502 & 2502 & 2502 & 2502 & 2502 & 2502 & 2502 & 2502 \\
\hline $\mathbf{R}^{2}$ & 0.4078 & 0.4367 & 0.4268 & 0.4426 & 0.4264 & 0.4270 & 0.4181 & 0.4152 & 0.4254 & 0.4429 & 0.4319 & 0.4388 \\
\hline
\end{tabular}

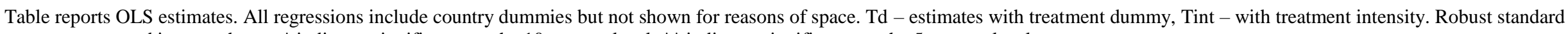
errors are reported in parentheses. * indicates significance at the 10 percent level, ** indicates significance at the 5 percent level 
Table D4. (continued)

\begin{tabular}{|c|c|c|c|c|c|c|c|c|c|c|c|c|}
\hline & \multirow{2}{*}{\multicolumn{2}{|c|}{$\begin{array}{c}\text { Productive } \\
\text { environment (all funds } \\
\text { ERDF+CF) }\end{array}$}} & \multicolumn{10}{|c|}{ 2. ERDF Objective 2} \\
\hline & & & \multicolumn{2}{|c|}{$\begin{array}{l}\text { All expenditure } \\
\text { categories }\end{array}$} & \multicolumn{2}{|c|}{$\begin{array}{l}\text { 2.1. Productive } \\
\text { environment }\end{array}$} & \multicolumn{2}{|c|}{ 2.2. Human resources } & \multicolumn{2}{|c|}{$\begin{array}{c}\text { 2.3. Basic } \\
\text { infrastructure }\end{array}$} & \multicolumn{2}{|c|}{ 2.4. Miscellaneous } \\
\hline & Td & Tint & Td & Tint & Td & Tint & Td & Tint & Td & Tint & Td & Tint \\
\hline \multirow{2}{*}{ const } & $0.0275^{*}$ & 0.0168 & $0.0263 *$ & $0.0295^{*}$ & $0.0266^{*}$ & $0.0303 *$ & $0.0329 * *$ & $0.0329 * *$ & $0.0289 *$ & $0.0306^{*}$ & $0.0280^{*}$ & $0.0316^{* *}$ \\
\hline & $(0.0162)$ & $(0.0162)$ & $(0.0159)$ & $(0.0158)$ & $(0.0159)$ & $(0.0158)$ & $(0.0159)$ & $(0.0159)$ & $(0.0159)$ & $(0.0159)$ & $(0.0159)$ & $(0.0158)$ \\
\hline \multirow{2}{*}{ Initial per capita GDP } & $-0.0042 * *$ & $-0.0044 * *$ & $-0.0037 * *$ & $-0.0038^{* *}$ & $-0.0037 * *$ & $-0.0039 * *$ & $-0.0040^{* *}$ & $-0.0040 * *$ & $-0.0038^{* *}$ & $-0.0039 * *$ & $-0.0038 * *$ & $-0.0039 * *$ \\
\hline & $(0.0015)$ & $(0.0014)$ & $(0.0014)$ & $(0.0014)$ & $(0.0014)$ & $(0.0014)$ & $(0.0015)$ & $(0.0015)$ & $(0.0014)$ & $(0.0015)$ & $(0.0014)$ & $(0.0014)$ \\
\hline \multirow{2}{*}{ Population growth } & 0.0185 & 0.0111 & 0.0163 & 0.0091 & 0.0152 & 0.0093 & 0.0027 & 0.0020 & 0.0064 & 0.0012 & 0.0147 & 0.0074 \\
\hline & $(0.0608)$ & $(0.0606)$ & $(0.0598)$ & $(0.0604)$ & $(0.0598)$ & $(0.0602)$ & $(0.0601)$ & $(0.0601)$ & $(0.0599)$ & $(0.0603)$ & $(0.0602)$ & $(0.0600)$ \\
\hline \multirow{2}{*}{ Agriculture } & $-0.0009 * *$ & $-0.0009 * *$ & $-0.0008 * *$ & $-0.0009 * *$ & $-0.0008 * *$ & $-0.0008 * *$ & $-0.0009 * *$ & $-0.0009 * *$ & $-0.0009 * *$ & $-0.0009 * *$ & $-0.0009 * *$ & $-0.0009 * *$ \\
\hline & $(0.0002)$ & $(0.0002)$ & $(0.0002)$ & $(0.0002)$ & $(0.0002)$ & $(0.0002)$ & $(0.0002)$ & $(0.0002)$ & $(0.0002)$ & $(0.0002)$ & $(0.0002)$ & $(0.0002)$ \\
\hline \multirow{2}{*}{ Industry } & $0.0005 * *$ & $0.0006^{* *}$ & $0.0005^{* *}$ & $0.0004 * *$ & $0.0005^{* *}$ & $0.0004 * *$ & $0.0004 * *$ & $0.0004 * *$ & $0.0004 * *$ & $0.0004 * *$ & $0.0005^{* *}$ & $0.0004 * *$ \\
\hline & $(0.0001)$ & $(0.0001)$ & $(0.0001)$ & $(0.0001)$ & $(0.0001)$ & $(0.0001)$ & $(0.0001)$ & $(0.0001)$ & $(0.0001)$ & $(0.0001)$ & $(0.0001)$ & $(0.0001)$ \\
\hline Service & $0.0003 * *$ & $0.0005 * *$ & $0.0003 * *$ & $0.0003 * *$ & $0.0003 * *$ & $0.0003 * *$ & $0.0003 * *$ & $0.0003 * *$ & $0.0003 * *$ & $0.0003 * *$ & $0.0003 * *$ & $0.0003 * *$ \\
\hline \multirow{2}{*}{ Capital dummy } & $0.0110 * *$ & $0.0111 * *$ & $0.0109 * *$ & $0.0109 * *$ & $0.0109 * *$ & $0.0109 * *$ & $0.0111 * *$ & $0.0110 * *$ & $0.0109 * *$ & $0.0110 * *$ & $0.0110 * *$ & $0.0108 * *$ \\
\hline & $(0.0021)$ & $(0.0020)$ & $(0.0021)$ & $(0.0021)$ & $(0.0021)$ & $(0.0021)$ & $(0.0021)$ & $(0.0021)$ & $(0.0021)$ & $(0.0021)$ & $(0.0021)$ & $(0.0021)$ \\
\hline \multirow{2}{*}{ Costal dummy } & 0.0002 & 0.0003 & 0.0003 & 0.0003 & 0.0003 & 0.0003 & 0.0002 & 0.0003 & 0.0003 & 0.0002 & 0.0002 & 0.0001 \\
\hline & $(0.0012)$ & $(0.0012)$ & $(0.0012)$ & $(0.0012)$ & $(0.0012)$ & $(0.0012)$ & $(0.0012)$ & $(0.0012)$ & $(0.0012)$ & $(0.0012)$ & $(0.0012)$ & $(0.0012)$ \\
\hline \multirow{2}{*}{ Port dummy } & $-0.0024 * *$ & $-0.0023 * *$ & $-0.0023 * *$ & $-0.0023^{* *}$ & $-0.0023 * *$ & $-0.0023 * *$ & $-0.0023^{* *}$ & $-0.0023 * *$ & $-0.0023 * *$ & $-0.0023 * *$ & $-0.0023 * *$ & $-0.0022 * *$ \\
\hline & $(0.0011)$ & $(0.0011)$ & $(0.0011)$ & $(0.0011)$ & $(0.0011)$ & $(0.0011)$ & $(0.0011)$ & $(0.0011)$ & $(0.0011)$ & $(0.0011)$ & $(0.0011)$ & $(0.0011)$ \\
\hline \multirow{2}{*}{ Urban dummy } & 0.0009 & 0.0005 & 0.0006 & 0.0007 & 0.0006 & 0.0006 & 0.0009 & 0.0009 & 0.0007 & 0.0008 & 0.0007 & 0.0009 \\
\hline & $(0.0011)$ & $(0.0011)$ & $(0.0011)$ & $(0.0011)$ & $(0.0011)$ & $(0.0011)$ & $(0.0012)$ & $(0.0011)$ & $(0.0011)$ & $(0.0011)$ & $(0.0011)$ & $(0.0011)$ \\
\hline \multirow{2}{*}{ Rural dummy } & -0.0002 & 0.0003 & $4,195 \mathrm{e}-05$ & $-1,865 \mathrm{e}-05$ & $2,880 \mathrm{e}-05$ & $2,298 \mathrm{e}-05$ & -0.0003 & -0.0002 & -0.0001 & -0.0002 & $-9,036 \mathrm{e}-05$ & -0.0001 \\
\hline & $(0.0010)$ & $(0.0010)$ & $(0.0010)$ & $(0.0010)$ & $(0.0010)$ & $(0.0010)$ & $(0.0010)$ & $(0.0010)$ & $(0.0010)$ & $(0.00010)$ & $(0.0010)$ & $(0.0010)$ \\
\hline \multirow{2}{*}{$\begin{array}{l}\text { Post-policy period } \\
\text { dummy }(t 2)\end{array}$} & $-0.0116^{* *}$ & $-0.0132 * *$ & $-0.0196 * *$ & $-0.0182 * *$ & $-0.0196 * *$ & $-0.0182 * *$ & $-0.0161 * *$ & $-0.0161 * *$ & $-0.0184 * *$ & $-0.0170 * *$ & $-0.0179 * *$ & $-0.0169 * *$ \\
\hline & $(0.0017)$ & $(0.0009)$ & $(0.0011)$ & $(0.0010)$ & $(0.0011)$ & $(0.0010)$ & $(0.0009)$ & $(0.0009)$ & $(0.0011)$ & $(0.0010)$ & $(0.0011)$ & $(0.0009)$ \\
\hline $\begin{array}{l}\text { Treatment group } \\
\text { dummy }(d T)\end{array}$ & $0.0039 * *$ & & $-0.0043 * *$ & & $-0.0042 * *$ & & -0.0003 & & $-0.0024 * *$ & & $-0.0032 * *$ & \\
\hline $\begin{array}{l}\text { Difference-in-difference } \\
\text { estimator }(t 2 \times d T)\end{array}$ & $(0.0018)$ & & $(0.0015)$ & & $(0.0015)$ & & $(0.0020)$ & & $(0.0015)$ & & $(0.0015)$ & \\
\hline \multirow{2}{*}{$\begin{array}{l}\text { Treatment intensity } \\
\text { (Tint) }\end{array}$} & & $0.0190 * *$ & & $-0.0327 * *$ & & $-0.0536^{* *}$ & & 0.004 & & -0.0328 & & $-0.6386 * *$ \\
\hline & & $(0.0030)$ & & $(0.0092)$ & & $(0.0131)$ & & $(0.1927)$ & & $(0.0227)$ & & $(0.2180)$ \\
\hline \multirow{2}{*}{$\begin{array}{l}\text { Post-policy period } \\
\text { dummy } * \text { Treatment } \\
\text { intensity }(t 2 \times \text { Tint })\end{array}$} & & $-0.0307 * *$ & & $0.0520 * *$ & & $0.0830 * *$ & & -0.1591 & & $0.0646 * *$ & & $0.8045^{* *}$ \\
\hline & & $(0.0036)$ & & $(0.0123)$ & & $(0.0175)$ & & $(0.2486)$ & & $(0.0306)$ & & $(0.2993)$ \\
\hline $\mathbf{n}$ & 2502 & 2502 & 2502 & 2502 & 2502 & 2502 & 2502 & 2502 & 2502 & 2502 & 2502 & 2502 \\
\hline $\mathbf{R}^{2}$ & 0.4079 & 0.4230 & 0.4108 & 0.4098 & 0.4106 & 0.4110 & 0.4054 & 0.4054 & 0.4080 & 0.4063 & 0.4074 & 0.4075 \\
\hline
\end{tabular}

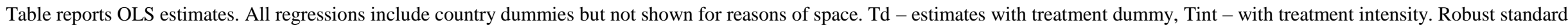
errors are reported in parentheses. * indicates significance at the 10 percent level, ** indicates significance at the 5 percent level 
Table D4. (continued)

\begin{tabular}{|c|c|c|c|c|c|c|c|c|c|c|c|c|}
\hline & \multirow{2}{*}{\multicolumn{2}{|c|}{$\begin{array}{l}\text { Human resources (all } \\
\text { funds ERDF+CF) }\end{array}$}} & \multirow{2}{*}{\multicolumn{2}{|c|}{$\begin{array}{l}\text { Basic infrastructure } \\
\text { (all funds ERDF+CF) }\end{array}$}} & \multirow{2}{*}{\multicolumn{2}{|c|}{$\begin{array}{c}\text { Miscellaneous (all funds } \\
\text { ERDF+CF) }\end{array}$}} & \multicolumn{6}{|c|}{ 3. Cohesion fund } \\
\hline & & & & & & & \multicolumn{2}{|c|}{ All expenditure } & \multicolumn{2}{|c|}{ 3.3. Basic } & \multicolumn{2}{|c|}{ 3.4. Miscellaneous } \\
\hline & Td & Tint & Td & Tint & Td & Tint & Td & Tint & Td & Tint & Td & Tint \\
\hline \multirow{2}{*}{ const } & 0.0294* & $0.0282 *$ & 0.0265 & 0.0251 & $0.0313 * *$ & $0.0349 * *$ & $0.0358 * *$ & $0.0313^{* * *}$ & $0.0358 * *$ & $0.0313 * *$ & $0.0333^{* *}$ & $0.0334 * *$ \\
\hline & $(0.0160)$ & (0.0159) & $(0.0161)$ & $(0.0155)$ & $(0.0159)$ & $(0.0155)$ & $(0.0156)$ & $(0.0158)$ & $(0.0156)$ & $(0.0158)$ & $(0.0158)$ & $(0.0158)$ \\
\hline \multirow{2}{*}{ Initial per capita GDP } & $-0.0042 * *$ & $-0.0041 * *$ & $-0.0042 * *$ & $-0.0039 * *$ & $-0.0043^{* *}$ & $-0.0045 * *$ & $-0.0032 * *$ & $-0.0035 * *$ & $-0.0032 * *$ & $-0.0035^{* *}$ & $-0.0039 * *$ & $-0.0043^{* *}$ \\
\hline & $(0.0014)$ & $(0.0014)$ & $(0.0015)$ & $(0.0014)$ & $(0.0014)$ & $(0.0014)$ & $(0.0014)$ & $(0.0014)$ & $(0.0014)$ & $(0.0014)$ & $(0.0015)$ & $(0.0014)$ \\
\hline \multirow{2}{*}{ Population growth } & 0.00533 & $-4,083 e-05$ & 0.0178 & 0.0658 & 0.0186 & 0.0156 & 0.0451 & 0.0184 & 0.0451 & 0.0187 & 0.0025 & 0.0143 \\
\hline & $(0.0604)$ & $(0.0594)$ & $(0.0605)$ & $\begin{array}{l}(0.0588) \\
\end{array}$ & $(0.0607)$ & $(0.0589)$ & $(0.0593)$ & $(0.0599)$ & $(0.0593)$ & $\begin{array}{l}(0.0599) \\
\end{array}$ & $(0.0598)$ & $\begin{array}{l}(0.0599) \\
\end{array}$ \\
\hline \multirow{2}{*}{ Agriculture } & $-0.0009^{* *}$ & $-0.0008^{* *}$ & $-0.0009^{* *}$ & $-0.0006 * *$ & $-0.00082 * *$ & $-0.0006 * *$ & $-0.0004 * *$ & $-0.0007 * *$ & $-0.0004 * *$ & $-0.0007 * *$ & $-0.0008^{* *}$ & $-0.0010^{* * *}$ \\
\hline & $(0.0002)$ & $(0.0002)$ & $(0.0002)$ & $(0.0002)$ & $(0.0002)$ & $(0.0002)$ & $(0.0002)$ & $(0.0002)$ & $(0.0002)$ & $(0.0002)$ & $(0.0002)$ & $(0.0002)$ \\
\hline \multirow{2}{*}{ Industry } & $0.0005^{* *}$ & $0.0005^{* *}$ & $0.0005^{* *}$ & $0.0005 * *$ & $0.0004 * *$ & $0.0004 * *$ & $0.0003 * *$ & $0.0004 * *$ & $0.0003^{* *}$ & $0.0004 * *$ & $0.0004^{* *}$ & $0.0004^{* * *}$ \\
\hline & $(0.0001)$ & $(0.0001)$ & $(0.0001)$ & $(0.0001)$ & $(0.0001)$ & $(0.0001)$ & $(0.0001)$ & $(0.0001)$ & $(0.0001)$ & $(0.0001)$ & $(0.0001)$ & $(0.0001)$ \\
\hline \multirow{2}{*}{ Service } & $0.0003 * *$ & $0.0003^{* *}$ & $0.0003 * *$ & $0.0004 * *$ & $0.0003^{* *}$ & $0.0003 * *$ & 0.0002 & $0.0003^{*}$ & 0.0002 & $0.0003^{*}$ & $0.0003 *$ & $0.0003^{* *}$ \\
\hline & $(0.00014)$ & $(0.0001)$ & $(0.0001)$ & $(0.0001)$ & $(0.0001)$ & $(0.0001)$ & $(0.0001)$ & $(0.0001)$ & $(0.0001)$ & $(0.0001)$ & $(0.0001)$ & $(0.0002)$ \\
\hline \multirow{2}{*}{ Capital dummy } & $0.0110^{* *}$ & $0.0112 * *$ & $0.0110 * *$ & $0.0108 * *$ & $0.0109^{* *}$ & $0.0109 * *$ & $0.0106 * *$ & $0.0107 * *$ & $0.0106^{* *}$ & $0.0107 * *$ & $0.0103^{* *}$ & $0.0112 * *$ \\
\hline & $(0.0021)$ & $(0.0021)$ & $(0.0021)$ & $(0.0020)$ & $(0.0021)$ & $(0.0020)$ & $(0.0020)$ & $(0.0021)$ & $(0.0020)$ & $(0.0021)$ & $(0.0021)$ & $(0.0021)$ \\
\hline \multirow{2}{*}{ Costal dummy } & 0.0002 & 0.0002 & 0.0003 & 0.0003 & 0.0002 & 0.0002 & 0.0003 & 0.0002 & 0.0003 & 0.0002 & 0.0003 & 0.0002 \\
\hline & (0.0012) & $(0.0012)$ & (0.0012) & $(0.0012)$ & $(0.0012)$ & $(0.0012)$ & $(0.0012)$ & $(0.0012)$ & $(0.0012)$ & $(0.0012)$ & $(0.0012)$ & (0.0012) \\
\hline \multirow{2}{*}{ Port dummy } & $-0.0023 * *$ & $-0.0023 * *$ & $-0.0024 * *$ & $-0.0024 * *$ & $-0.0023 * *$ & $-0.0023 * *$ & $-0.0023 * *$ & $-0.0023 * *$ & $-0.0023 * *$ & $-0.0023 * *$ & $-0.0024 * *$ & $-0.0023^{* *}$ \\
\hline & $(0.0011)$ & $(0.0011)$ & $(0.0011)$ & $(0.0011)$ & $(0.0011)$ & $(0.0011)$ & $(0.0011)$ & $(0.0011)$ & $(0.0011)$ & $(0.0011)$ & $(0.0011)$ & $(0.0011)$ \\
\hline \multirow{2}{*}{ Urban dummy } & 0.0007 & 0.0007 & 0.0008 & 0.0001 & 0.0008 & 0.0003 & 0.0003 & 0.0006 & 0.0003 & 0.0006 & 0.0008 & 0.0010 \\
\hline & $(0.0011)$ & $(0.0011)$ & $(0.0011)$ & $(0.0010)$ & $(0.0011)$ & $(0.0010)$ & $(0.0010)$ & $(0.0011)$ & $(0.0010)$ & $(0.0011)$ & $(0.0011)$ & $(0.0011)$ \\
\hline \multirow{2}{*}{ Rural dummy } & -0.0001 & $6,514 \mathrm{e}-05$ & -0.0001 & 0.0006 & $-7,051 \mathrm{e}-05$ & 0.0004 & 0.0006 & $3,089 \mathrm{e}-05$ & 0.0006 & $3,494 \mathrm{e}-05$ & -0.0001 & -0.0004 \\
\hline & $(0.0010)$ & $(0.0010)$ & $(0.0010)$ & $(0.0010)$ & $(0.0010)$ & $(0.0010)$ & $(0.0010)$ & $(0.0010)$ & $(0.0010)$ & $(0.0010)$ & $(0.0010)$ & $(0.0010)$ \\
\hline \multirow{2}{*}{$\begin{array}{l}\text { Post-policy period } \\
\text { dummy }(t 2)\end{array}$} & $-0.0131 * *$ & $-0.0149 * *$ & $-0.0111 * *$ & $-0.0140 * *$ & $-0.0106 * *$ & $-0.0141 * *$ & $-0.0140 * *$ & $-0.0156 * *$ & $-0.0140 * *$ & $-0.0156 * *$ & $-0.0159 * *$ & $-0.0163 * *$ \\
\hline & $(0.0012)$ & $(0.0009)$ & $(0.0016)$ & $(0.0009)$ & $(0.0015)$ & $(0.0009)$ & $(0.0009)$ & $(0.0009)$ & $(0.0009)$ & $(0.0009)$ & $(0.0009)$ & $(0.0009)$ \\
\hline \multirow{2}{*}{$\begin{array}{l}\text { Treatment group } \\
\text { dummy }(d T)\end{array}$} & $0.0029 * *$ & & $0.0045 * *$ & & $0.0041 * *$ & & $0.0161 * *$ & & $0.0161^{* *}$ & & $0.0125 * *$ & \\
\hline & $(0.0011)$ & & $(0.0013)$ & & $(0.0013)$ & & $(0.0024)$ & & $(0.0024)$ & & $(0.0033)$ & \\
\hline \multirow{2}{*}{$\begin{array}{l}\text { Difference-in-difference } \\
\text { estimator }(t 2 \times d T)\end{array}$} & $-0.0058^{* *}$ & & $-0.0068^{* *}$ & & $-0.0078^{* *}$ & & $-0.0173^{* *}$ & & $-0.0173^{* *}$ & & $-0.0046^{*}$ & \\
\hline & $(0.0015)$ & & $(0.0017)$ & & $(0.0017)$ & & $(0.0019)$ & & $(0.0019)$ & & $(0.0026)$ & \\
\hline \multirow{2}{*}{$\begin{array}{l}\text { Treatment intensity } \\
\text { (Tint) }\end{array}$} & & $0.1479 * *$ & & 0.0070 ** & & $0.2281 * *$ & & $0.0067^{* * *}$ & & $0.0069 * *$ & & $-0.2668 * *$ \\
\hline & & $(0.0271)$ & & $(0.0009)$ & & $(0.0317)$ & & $(0.0022)$ & & $(0.0022)$ & & $(0.1257)$ \\
\hline \multirow{2}{*}{$\begin{array}{l}\text { Post-policy period } \\
\text { dummy } * \text { Treatment } \\
\text { intensity }(t 2 \times \text { Tint })\end{array}$} & & $-0.240 * *$ & & $-0.0119 * *$ & & $-0.3982 * *$ & & $-0.0124 * *$ & & $-0.0127^{* *}$ & & $0.3901 * *$ \\
\hline & & $(0.0364)$ & & $(0.0010)$ & & $(0.0381)$ & & $(0.0027)$ & & $(0.0027)$ & & $(0.1283)$ \\
\hline $\mathrm{n}$ & 2502 & 2502 & 2502 & 2502 & 2502 & 2502 & 2502 & 2502 & 2502 & 2502 & 2502 & 2502 \\
\hline $\mathbf{R}^{2}$ & 0.4089 & 0.4160 & 0.4092 & 0.4360 & 0.4105 & 0.4307 & 0.4264 & 0.4103 & 0.4264 & 0.4105 & 0.4088 & 0.4076 \\
\hline
\end{tabular}

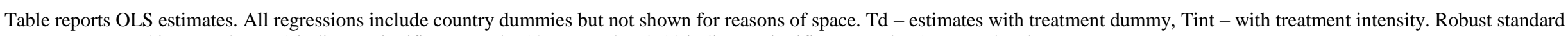
errors are reported in parentheses. * indicates significance at the 10 percent level, ** indicates significance at the 5 percent level 
Table D4. (continued)

\begin{tabular}{|c|c|c|c|c|c|c|c|c|c|c|}
\hline & \multicolumn{10}{|c|}{ 4. ERDF Urban } \\
\hline & \multicolumn{2}{|c|}{$\begin{array}{l}\text { All expenditure } \\
\text { categories }\end{array}$} & \multicolumn{2}{|c|}{$\begin{array}{l}\text { 4.1. Productive } \\
\text { environment }\end{array}$} & \multicolumn{2}{|c|}{ 4.2. Human resources } & \multicolumn{2}{|c|}{$\begin{array}{c}\text { 4.3. Basic } \\
\text { infrastructure }\end{array}$} & \multicolumn{2}{|c|}{ 4.4. Miscellaneous } \\
\hline & Td & Tint & Td & Tint & Td & Tint & Td & Tint & Td & Tint \\
\hline \multirow{2}{*}{ const } & $0.0320 * *$ & $0.0315^{* *}$ & $0.0322 * *$ & $0.0320^{* * *}$ & $0.0319 * *$ & $0.0322 * *$ & $0.0321 * *$ & $0.0317 * *$ & $0.0322 * *$ & $0.0314 * *$ \\
\hline & $(0.0159)$ & $(0.0159)$ & $(0.0159)$ & $(0.0159)$ & $\begin{array}{l}(0.0159) \\
\end{array}$ & $(0.0159)$ & $(0.0159)$ & $\begin{array}{l}(0.0159) \\
\end{array}$ & (0.0158) & $(0.0159)$ \\
\hline \multirow{2}{*}{ Initial per capita GDP } & $-0.0040 * *$ & $-0.0041 * *$ & $-0.0040^{* *}$ & $-0.0040 * *$ & $-0.0040 * *$ & $-0.0041 * *$ & $-0.0040 * *$ & $-0.0041 * *$ & $-0.0041 * *$ & $-0.0041^{* *}$ \\
\hline & $(0.0014)$ & $(0.0014)$ & $(0.0014)$ & $(0.0014)$ & $(0.0014)$ & $(0.0014)$ & $(0.0014)$ & $(0.0014)$ & $(0.0014)$ & $(0.0014)$ \\
\hline \multirow{2}{*}{ Population growth } & 0.0200 & 0.0153 & 0.0192 & 0.0107 & 0.0185 & 0.0128 & 0.0195 & 0.0123 & 0.0180 & 0.0164 \\
\hline & $(0.0602)$ & $(0.0602)$ & $(0.0602)$ & $(0.0601)$ & $(0.0602)$ & $(0.0602)$ & $(0.0602)$ & $(0.0601)$ & $(0.0602)$ & $(0.0602)$ \\
\hline \multirow{2}{*}{ Agriculture } & $-0.0009 * *$ & $-0.0009 * *$ & $-0.0009 * *$ & $-0.0009 * *$ & $-0.0009 * *$ & $-0.0009^{* *}$ & $-0.0009 * *$ & $-0.0009 * *$ & $-0.0009 * *$ & $-0.0009^{* *}$ \\
\hline & $(0.0002)$ & $(0.0002)$ & $(0.0002)$ & $(0.0002)$ & $(0.0002)$ & $(0.0002)$ & $(0.0002)$ & $(0.0002)$ & (0.0002) & $(0.0002)$ \\
\hline \multirow{2}{*}{ Industry } & $0.0004 * *$ & $0.0004 * *$ & $0.0004 * *$ & $0.0004 * *$ & $0.0004 * *$ & $0.0004 * *$ & $0.0004 * *$ & $0.0004 * *$ & $0.0004 * *$ & $0.0004 * *$ \\
\hline & $(0.0001)$ & $(0.0001)$ & $(0.0001)$ & $(0.0001)$ & $(0.0001)$ & $(0.0001)$ & $(0.0001)$ & $(0.0001)$ & $\begin{array}{l}(0.0001) \\
\end{array}$ & $(0.0001)$ \\
\hline \multirow{2}{*}{ Service } & $0.0003 * *$ & $0.0003 * *$ & $0.0003 * *$ & $0.0003^{* * *}$ & $0.0003 * *$ & $0.0003 * *$ & $0.0003 * *$ & $0.0003 * *$ & $0.0003 * *$ & $0.0003 * *$ \\
\hline & $(0.0001)$ & $(0.0001)$ & $(0.0001)$ & $(0.0001)$ & $(0.000)$ & $(0.0001)$ & $(0.0001)$ & $(0.0001)$ & $(0.0001)$ & $(0.0001)$ \\
\hline \multirow{2}{*}{ Capital dummy } & $0.0110^{* *}$ & $0.0111^{* *}$ & $0.0109 * *$ & $0.0111^{* *}$ & $0.0110^{* *}$ & $0.0111 * *$ & $0.0110^{* *}$ & $0.0110^{* *}$ & $0.0111 * *$ & $0.0111^{* *}$ \\
\hline & $(0.0021)$ & $(0.0021)$ & $(0.0021)$ & $(0.0021)$ & $(0.0021)$ & $(0.0021)$ & $(0.0021)$ & $(0.0021)$ & $(0.0021)$ & $(0.0021)$ \\
\hline \multirow{2}{*}{ Costal dummy } & 0.0002 & 0.0002 & 0.0002 & 0.0001 & 0.0002 & 0.0002 & 0.0002 & 0.0002 & 0.0002 & 0.00016 \\
\hline & $(0.0012)$ & $(0.0012)$ & $(0.0012)$ & $(0.0012)$ & $(0.0012)$ & $(0.0012)$ & $(0.0012)$ & $(0.0012)$ & $(0.0012)$ & $(0.0012)$ \\
\hline \multirow{2}{*}{ Port dummy } & $-0.0023 * *$ & $-0.0023 * *$ & $-0.0023^{* *}$ & $-0.0023 * *$ & $-0.0023 * *$ & $-0.0023^{* *}$ & $-0.0023 * *$ & $-0.0023 * *$ & $-0.0023 * *$ & $-0.0023^{* *}$ \\
\hline & $(0.0011)$ & $(0.0011)$ & $(0.0011)$ & $(0.0011)$ & $(0.0011)$ & $(0.0011)$ & $(0.0011)$ & $(0.0011)$ & $(0.0011)$ & $(0.0011)$ \\
\hline \multirow{2}{*}{ Urban dummy } & 0.0009 & 0.0008 & 0.0008 & 0.0009 & 0.0009 & 0.0008 & 0.0009 & 0.0008 & 0.0009 & 0.0008 \\
\hline & $(0.0011)$ & $(0.0011)$ & $(0.0011)$ & $(0.0011)$ & $(0.0011)$ & $(0.0011)$ & $(0.0011)$ & $(0.0011)$ & $(0.0011)$ & $(0.0011)$ \\
\hline \multirow{2}{*}{ Rural dummy } & -0.0003 & -0.0002 & -0.0002 & -0.0002 & -0.0002 & -0.0002 & -0.0002 & -0.0002 & -0.0002 & -0.0002 \\
\hline & $(0.0010)$ & $(0.0010)$ & $(0.0010)$ & $(0.0010)$ & $\begin{array}{l}(0.0010) \\
\end{array}$ & $(0.0010)$ & (0.0010) & $\begin{array}{l}(0.0010) \\
\end{array}$ & $\begin{array}{l}(0.0010) \\
\end{array}$ & $(0.0010)$ \\
\hline \multirow{2}{*}{$\begin{array}{l}\text { Post-policy period } \\
\text { dummy }(t 2)\end{array}$} & $-0.0157^{* *}$ & -0.0160 ** & $-0.0158^{* *}$ & $-0.0162 * *$ & $-0.0158 * *$ & $-0.0161 * *$ & $-0.0157^{* *}$ & $-0.0161 * *$ & $-0.0157 * *$ & -0.0160 ** \\
\hline & $(0.0009)$ & $(0.0009)$ & $(0.0009)$ & $(0.0009)$ & $(0.0009)$ & $(0.0009)$ & $(0.0009)$ & $(0.0009)$ & $(0.0009)$ & $(0.0009)$ \\
\hline \multirow{2}{*}{$\begin{array}{l}\text { Treatment group } \\
\text { dummy }(d T)\end{array}$} & $0.0040^{*}$ & & $0.0047 * *$ & & $0.0044 *$ & & $0.0044 * *$ & & $0.0042 *$ & \\
\hline & $(0.0022)$ & & $(0.0024)$ & & $(0.0023)$ & & $(0.0022)$ & & $\begin{array}{l}(0.0022) \\
\end{array}$ & \\
\hline \multirow{2}{*}{$\begin{array}{l}\text { Difference-in-difference } \\
\text { estimator }(t 2 \times d T)\end{array}$} & $-0.0083^{* *}$ & & $-0.0080 * *$ & & $-0.0086^{* *}$ & & $-0.0084 * *$ & & $-0.0086^{* *}$ & \\
\hline & $(0.0030)$ & & $(0.0033)$ & & $(0.0032)$ & & $(0.0031)$ & & $(0.0031)$ & \\
\hline \multirow{2}{*}{$\begin{array}{l}\text { Treatment intensity } \\
\text { (Tint) }\end{array}$} & & $0.1765^{* *}$ & & 0.4958 & & 0.9377 & & $0.2384 * *$ & & $2,8630 * *$ \\
\hline & & $(0.0778)$ & & $(0.3785)$ & & $(0.5778)$ & & $(0.1061)$ & & $(1,2790)$ \\
\hline \multirow{2}{*}{$\begin{array}{l}\text { Post-policy period } \\
\text { dummy } * \text { Treatment } \\
\text { intensity }(t 2 \times \text { Tint })\end{array}$} & & $-0.2290 * *$ & & -0.1530 & & $-1,0530$ & & $-0.3520^{* *}$ & & $-3,9630^{* *}$ \\
\hline & & $(0.1092)$ & & $(0.5323)$ & & $(0.8114)$ & & $(0.1492)$ & & $(1,7980)$ \\
\hline $\mathrm{n}$ & 2502 & 2502 & 2502 & 2502 & 2502 & 2502 & 2502 & 2502 & 2502 & 2502 \\
\hline $\mathbf{R}^{2}$ & 0.4071 & 0.4066 & 0.4067 & 0.4059 & 0.4070 & 0.4059 & 0.4071 & 0.4068 & 0.4071 & 0.4066 \\
\hline
\end{tabular}

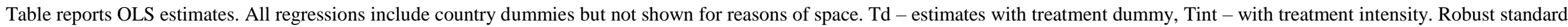
errors are reported in parentheses. * indicates significance at the 10 percent level, ** indicates significance at the 5 percent level 
Table D4. (continued)

\begin{tabular}{|c|c|c|c|c|c|c|c|c|c|c|}
\hline & \multicolumn{10}{|c|}{ 5. ERDF INTERREG IIIA } \\
\hline & \multicolumn{2}{|c|}{$\begin{array}{c}\text { All expenditure } \\
\text { categories }\end{array}$} & \multicolumn{2}{|c|}{$\begin{array}{c}\text { 5.1. Productive } \\
\text { environment }\end{array}$} & \multicolumn{2}{|c|}{ 5.2. Human resources } & \multicolumn{2}{|c|}{$\begin{array}{c}\text { 5.3. Basic } \\
\text { infrastructure }\end{array}$} & \multicolumn{2}{|c|}{ 5.4. Miscellaneous } \\
\hline & Td & Tint & Td & Tint & Td & Tint & Td & Tint & Td & Tint \\
\hline \multirow{2}{*}{ const } & $0.0326 * *$ & $0.0331 * *$ & $0.0326^{* *}$ & $0.0331^{* *}$ & $0.0325 * *$ & $0.0325^{* *}$ & $0.0326^{* * *}$ & $0.0323^{* *}$ & $0.0326^{* *}$ & $0.0342 * *$ \\
\hline & $(0.0159)$ & $(0.0158)$ & $(0.0159)$ & $(0.0159)$ & $(0.0159)$ & $(0.0159)$ & $(0.0159)$ & $(0.0157)$ & $(0.0159)$ & $(0.0158)$ \\
\hline \multirow{2}{*}{ Initial per capita GDP } & $-0.0040 * *$ & $-0.0042 * *$ & $-0.0040 * *$ & $-0.0041 * *$ & $-0.0040 * *$ & $-0.0040 * *$ & $-0.0040^{* *}$ & $-0.0044 * *$ & $-0.0040 * *$ & $-0.0041^{* *}$ \\
\hline & $(0.0014)$ & $(0.0014)$ & $(0.0014)$ & $(0.0014)$ & $(0.0015)$ & $(0.0015)$ & $(0.0014)$ & $(0.0014)$ & $(0.0014)$ & $(0.0014)$ \\
\hline \multirow{2}{*}{ Population growth } & 0.0012 & 0.0137 & 0.0012 & 0.0007 & 0.0026 & 0.0033 & 0.0012 & 0.0231 & 0.0012 & 0.0060 \\
\hline & $(0.0600)$ & $(0.0598)$ & $(0.0600)$ & $(0.0600)$ & $(0.0600)$ & $(0.0600)$ & $(0.0600)$ & $(0.0597)$ & $(0.0600)$ & $(0.0598)$ \\
\hline \multirow{2}{*}{ Agriculture } & $-0.0009 * *$ & $-0.0008 * *$ & $-0.0009 * *$ & $-0.0009 * *$ & $-0.0009 * *$ & $-0.0009 * *$ & $-0.0009 * *$ & $-0.0008 * *$ & $-0.0009 * *$ & $-0.0008 * *$ \\
\hline & $(0.0002)$ & $(0.0002)$ & $(0.0002)$ & $(0.0002)$ & $(0.0002)$ & $(0.0002)$ & $(0.0002)$ & $(0.0002)$ & $(0.0002)$ & $(0.0002)$ \\
\hline \multirow{2}{*}{ Industry } & $0.0004 * *$ & $0.0004 * *$ & $0.0004 * *$ & $0.0004 * *$ & $0.0004 * *$ & $0.0004 * *$ & $0.0004 * *$ & $0.0004 * *$ & $0.0004 * *$ & $0.0004 * *$ \\
\hline & $(0.0001)$ & $(0.0001)$ & $(0.0001)$ & $(0.0001)$ & $(0.0001)$ & $(0.0001)$ & $(0.0001)$ & $(0.0001)$ & $(0.0001)$ & $(0.0001)$ \\
\hline \multirow{2}{*}{ Service } & $0.0003 * *$ & $0.0003 * *$ & $0.0003 * *$ & $0.0003^{* * *}$ & $0.0003 * *$ & $0.0003 * *$ & $0.0003^{* * *}$ & $0.0003^{* * *}$ & $0.0003^{* * *}$ & $0.0003 * *$ \\
\hline & $(0.0001)$ & $(0.0001)$ & $(0.0001)$ & $(0.0001)$ & $(0.0001)$ & $(0.0001)$ & $(0.0001)$ & $(0.0001)$ & $(0.0001)$ & $(0.0001)$ \\
\hline \multirow{2}{*}{ Capital dummy } & $0.0110 * *$ & $0.0109^{* *}$ & $0.0110^{* *}$ & $0.0110^{* *}$ & $0.0111^{* *}$ & $0.0110^{* *}$ & $0.0110^{* *}$ & $0.0108 * *$ & $0.0110 * *$ & $0.0109 * *$ \\
\hline & $(0.0021)$ & $(0.0021)$ & $(0.0021)$ & $(0.0021)$ & $(0.0021)$ & $(0.0021)$ & $(0.0021)$ & $(0.0021)$ & $(0.0021)$ & $(0.002)$ \\
\hline \multirow{2}{*}{ Costal dummy } & 0.0002 & 0.0002 & 0.0002 & 0.0002 & 0.0002 & 0.0002 & 0.0002 & 0.0002 & 0.0002 & 0.0002 \\
\hline & $(0.0012)$ & $(0.0012)$ & $(0.0012)$ & $(0.0012)$ & $(0.0012)$ & $(0.0012)$ & $(0.0012)$ & $(0.0012)$ & $(0.0012)$ & (0.0012) \\
\hline \multirow{2}{*}{ Port dummy } & $-0.0022 * *$ & $-0.0023^{* *}$ & $-0.0022 * *$ & $-0.0023^{* *}$ & $-0.0023^{* *}$ & $-0.0023^{* *}$ & $-0.0022^{* *}$ & $-0.0023^{* *}$ & $-0.0022 * *$ & $-0.0023 * *$ \\
\hline & $(0.0011)$ & $(0.0011)$ & $(0.0011)$ & $(0.0011)$ & $(0.0011)$ & $(0.0011)$ & $(0.0011)$ & $(0.0011)$ & $(0.0011)$ & $(0.0011)$ \\
\hline \multirow{2}{*}{ Urban dummy } & 0.0007 & 0.0006 & 0.0007 & 0.0007 & 0.0008 & 0.0007 & 0.0007 & 0.0005 & 0.0007 & 0.0007 \\
\hline & $(0.0011)$ & $(0.0011)$ & $(0.0011)$ & $(0.0011)$ & $(0.0011)$ & $(0.0011)$ & $(0.0011)$ & $(0.0011)$ & $(0.0011)$ & $(0.0010)$ \\
\hline \multirow{2}{*}{ Rural dummy } & -0.0002 & $-6,815 \mathrm{e}-05$ & -0.0002 & -0.0002 & -0.0002 & -0.0002 & -0.0002 & $6,539 \mathrm{e}^{-05}$ & -0.0002 & -0.0001 \\
\hline & $(0.0010)$ & $(0.0010)$ & $(0.0010)$ & $(0.0010)$ & $(0.0010)$ & $(0.0010)$ & $(0.0010)$ & $(0.0010)$ & $(0.0010)$ & $(0.0010)$ \\
\hline \multirow{2}{*}{$\begin{array}{l}\text { Post-policy period } \\
\text { dummy }(t 2)\end{array}$} & $-0.0158^{* *}$ & $-0.0155^{* *}$ & \begin{tabular}{|l|}
$-0.0158^{* *}$ \\
\end{tabular} & \begin{tabular}{|c|}
$-0.0161 * *$ \\
\end{tabular} & \begin{tabular}{|l|}
$-0.0160^{* * *}$ \\
\end{tabular} & \begin{tabular}{|c|}
$-0.0158 * *$ \\
\end{tabular} & \begin{tabular}{|l|}
$-0.0158 * *$ \\
\end{tabular} & $-0.0154 * *$ & $-0.0158 * *$ & $-0.0156^{* *}$ \\
\hline & $(0.0010)$ & $(0.0009)$ & $(0.0010)$ & $(0.0009)$ & $(0.0010)$ & $\begin{array}{l}(0.0009) \\
\end{array}$ & $(0.0010)$ & $\begin{array}{l}(0.0009) \\
\end{array}$ & $(0.0010)$ & $(0.0009)$ \\
\hline \multirow{2}{*}{$\begin{array}{l}\text { Treatment group } \\
\text { dummy }(d T)\end{array}$} & 0.0003 & & 0.0003 & & 0.0003 & & 0.0003 & & 0.0002 & \\
\hline & $(0.0012)$ & & $(0.0012)$ & & $(0.0012)$ & & $(0.0012)$ & & $(0.0012)$ & \\
\hline \multirow{2}{*}{$\begin{array}{l}\text { Difference-in-difference } \\
\text { estimator }(t 2 \times d T)\end{array}$} & -0.0015 & & -0.0015 & & -0.0008 & & -0.0015 & & -0.0015 & \\
\hline & $(0.0015)$ & & $(0.0015)$ & & $(0.0016)$ & & $(0.0015)$ & & $(0.0015)$ & \\
\hline \multirow{2}{*}{$\begin{array}{l}\text { Treatment intensity } \\
\text { (Tint) }\end{array}$} & & $0.0334 * *$ & & 0.0074 & & 0.2565 & & $0.0980^{* *}$ & & $0.3276^{*}$ \\
\hline & & $(0.0134)$ & & $(0.0295)$ & & $(0.2176)$ & & $(0.0250)$ & & $(0.1674)$ \\
\hline \multirow{2}{*}{$\begin{array}{l}\text { Post-policy period } \\
\text { dummy } * \text { Treatment } \\
\text { intensity }(t 2 \times \text { Tint })\end{array}$} & & $-0.0823^{* *}$ & & -0.0518 & & $-0.6390^{* *}$ & & $-0.2181^{* *}$ & & $-0.8338^{* *}$ \\
\hline & & $(0.0181)$ & & $(0.0406)$ & & $(0.2966)$ & & $(0.0332)$ & & $(0.2227)$ \\
\hline $\mathbf{n}$ & 2502 & 2502 & 2502 & 2502 & 2502 & 2502 & 2502 & 2502 & 2502 & 2502 \\
\hline $\mathbf{R}^{2}$ & 0.4055 & 0.4104 & 0.4055 & 0.4058 & 0.4053 & 0.4064 & 0.4055 & 0.4156 & 0.4056 & 0.4087 \\
\hline
\end{tabular}

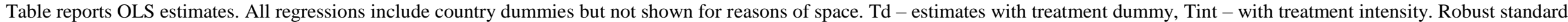
errors are reported in parentheses. * indicates significance at the 10 percent level, ** indicates significance at the 5 percent level 
Table E1. Estimated DiD parameters for alternative post-policy periods

\begin{tabular}{|c|c|c|c|c|}
\hline \multirow{3}{*}{ Fund / expenditure category } & \multicolumn{4}{|c|}{ Two alternative post-policy periods } \\
\hline & \multicolumn{2}{|c|}{$2009-2014$} & \multicolumn{2}{|c|}{$2010-2014$} \\
\hline & Td & Tint & Td & Tint \\
\hline All funds and all exp. cat. & $\begin{array}{l}-0.006^{*} \\
(0.002)\end{array}$ & $\begin{array}{c}-0.009 * \\
(0.001)\end{array}$ & $\begin{array}{c}-0.006^{*} \\
(0.002)\end{array}$ & $\begin{array}{c}-0.011^{*} \\
(0.001)\end{array}$ \\
\hline $\begin{array}{l}\text { 1. ERDF Objective } 1 \\
\text { (all exp. cat.) }\end{array}$ & $\begin{array}{c}-0.016^{*} \\
(0.002)\end{array}$ & $\begin{array}{c}-0.011^{*} \\
(0.001)\end{array}$ & $\begin{array}{c}-0.017 * \\
(0.010)\end{array}$ & $\begin{array}{c}-0.014 * \\
(0.001)\end{array}$ \\
\hline 1.1. Productive environment & $\begin{array}{c}-0.015^{*} \\
(0.002)\end{array}$ & $\begin{array}{c}-0.027 * \\
(0.004)\end{array}$ & $\begin{array}{c}-0.017 * \\
(0.002)\end{array}$ & $\begin{array}{c}-0.035^{*} \\
(0.004)\end{array}$ \\
\hline 1.2. Human resources & $\begin{array}{c}-0.021 * \\
(0.002)\end{array}$ & $\begin{array}{c}-0.214 * \\
(0.040)\end{array}$ & $\begin{array}{c}-0.018^{*} \\
(0.002)\end{array}$ & $\begin{array}{c}-0.262^{*} \\
(0.039) \\
\end{array}$ \\
\hline 1.3. Basic infrastructure & $\begin{array}{l}-0.015^{*} \\
(0.002)\end{array}$ & $\begin{array}{l}-0.015^{*} \\
(0.002)\end{array}$ & $\begin{array}{c}-0.017 * \\
(0.002)\end{array}$ & $\begin{array}{c}-0.019 * \\
(0.002)\end{array}$ \\
\hline 1.4. Miscellaneous & $\begin{array}{c}-0.016^{*} \\
(0.002) \\
\end{array}$ & $\begin{array}{c}-0.501^{*} \\
(0.045) \\
\end{array}$ & $\begin{array}{c}-0.019 * \\
(0.002)\end{array}$ & $\begin{array}{c}-0.551^{*} \\
(0.043) \\
\end{array}$ \\
\hline $\begin{array}{l}\text { 2. ERDF Objective } 2 \\
\text { (all exp. cat.) }\end{array}$ & $\begin{array}{l}0.008^{*} \\
(0.002)\end{array}$ & $\begin{array}{l}0.045^{*} \\
(0.013)\end{array}$ & $\begin{array}{l}0.008^{*} \\
(0.002)\end{array}$ & $\begin{array}{l}0.052 * \\
(0.013)\end{array}$ \\
\hline 2.1. Productive environment & $\begin{array}{l}0.007^{*} \\
(0.002) \\
\end{array}$ & $\begin{array}{l}0.073^{*} \\
(0.019) \\
\end{array}$ & $\begin{array}{l}0.008^{*} \\
(0.002) \\
\end{array}$ & $\begin{array}{l}0.084 * \\
(0.019) \\
\end{array}$ \\
\hline 2.2. Human resources & $\begin{array}{l}-0.005 \\
(0.002) \\
\end{array}$ & $\begin{array}{c}-0.636 * * * \\
(0.269)\end{array}$ & $\begin{array}{l}-0.003 \\
(0.002) \\
\end{array}$ & $\begin{array}{l}-0.246 \\
(0.262) \\
\end{array}$ \\
\hline 2.3. Basic infrastructure & $\begin{array}{l}0.006^{*} \\
(0.002) \\
\end{array}$ & $\begin{array}{c}0.063 * * \\
(0.033) \\
\end{array}$ & $\begin{array}{l}0.006^{*} \\
(0.002) \\
\end{array}$ & $\begin{array}{l}0.062 * * \\
(0.033) \\
\end{array}$ \\
\hline 2.4. Miscellaneous & $\begin{array}{l}0.004^{*} \\
(0.002)\end{array}$ & $\begin{array}{l}0.692^{*} \\
(0.325)\end{array}$ & $\begin{array}{l}0.005^{*} \\
(0.002)\end{array}$ & $\begin{array}{l}0.741 * \\
(0.315)\end{array}$ \\
\hline $\begin{array}{l}\text { 3. Cohesion fund } \\
\text { (all exp. cat.) }\end{array}$ & $\begin{array}{l}-0.018^{*} \\
(0.002)\end{array}$ & $\begin{array}{l}-0.012 * \\
(0.003)\end{array}$ & $\begin{array}{l}-0.020^{*} \\
(0.002)\end{array}$ & $\begin{array}{c}-0.013 * \\
(0.003)\end{array}$ \\
\hline 3.3. Basic infrastructure & $\begin{array}{l}-0.018^{*} \\
(0.002)\end{array}$ & $\begin{array}{c}-0.013 * \\
(0.003)\end{array}$ & $\begin{array}{c}-0.020^{*} \\
(0.002)\end{array}$ & $\begin{array}{c}-0.014 * \\
(0.003)\end{array}$ \\
\hline 3.4. Miscellaneous & $\begin{array}{c}0.001 \\
(0.003) \\
\end{array}$ & $\begin{array}{c}0.200 \\
(0.140) \\
\end{array}$ & $\begin{array}{c}-0.006 * * * \\
(0.003)\end{array}$ & $\begin{array}{l}0.409 * \\
(0.135) \\
\end{array}$ \\
\hline 4. Urban (all exp. cat.) & $\begin{array}{c}-0.005 * * * \\
(0.003)\end{array}$ & $\begin{array}{l}-0.117 \\
(0.119)\end{array}$ & $\begin{array}{c}-0.009 * \\
(0.003)\end{array}$ & $\begin{array}{c}-0.250^{* *} \\
(0.115)\end{array}$ \\
\hline 4.1. Productive environment & $\begin{array}{l}-0.003 \\
(0.004)\end{array}$ & $\begin{array}{c}0.342 \\
(0.577)\end{array}$ & $\begin{array}{c}-0.008 * * \\
(0.004)\end{array}$ & $\begin{array}{l}-0.120 \\
(0.560)\end{array}$ \\
\hline 4.2. Human resources & $\begin{array}{l}-0.006^{*} \\
(0.004)\end{array}$ & $\begin{array}{l}-0.541 \\
(0.880)\end{array}$ & $\begin{array}{l}-0.009 * \\
(0.004)\end{array}$ & $\begin{array}{l}-1.012 \\
(0.853)\end{array}$ \\
\hline 4.3. Basic infrastructure & $\begin{array}{c}-0.006 * * * \\
(0.003)\end{array}$ & $\begin{array}{l}-0.211 \\
(0.162)\end{array}$ & $\begin{array}{c}-0.009 * \\
(0.003)\end{array}$ & $\begin{array}{c}-0.394 * * \\
(0.157)\end{array}$ \\
\hline 4.4. Miscellaneous & $\begin{array}{c}-0.005 * * * \\
(0.003) \\
\end{array}$ & $\begin{array}{l}-2.262 \\
(1.951) \\
\end{array}$ & $\begin{array}{c}-0.009 * \\
(0.003) \\
\end{array}$ & $\begin{array}{c}-4.165 * * \\
(1.891) \\
\end{array}$ \\
\hline $\begin{array}{l}\text { 5. ERDF INTERREG IIIA } \\
\text { (all exp. cat.) }\end{array}$ & $\begin{array}{c}-0.003 * * \\
(0.002)\end{array}$ & $\begin{array}{c}-0.059 * \\
(0.020)\end{array}$ & $\begin{array}{l}-0.002 \\
(0.002)\end{array}$ & $\begin{array}{c}-0.093 * \\
(0.019)\end{array}$ \\
\hline 5.1. Productive environment & $\begin{array}{c}-0.003 * * \\
(0.002) \\
\end{array}$ & $\begin{array}{c}0.001 \\
(0.044) \\
\end{array}$ & $\begin{array}{l}-0.002 \\
(0.002) \\
\end{array}$ & $\begin{array}{l}-0.057 \\
(0.043) \\
\end{array}$ \\
\hline 5.2. Human resources & $\begin{array}{c}-0.002 * * * \\
(0.002)\end{array}$ & $\begin{array}{c}-0.467 * * * \\
(0.322)\end{array}$ & $\begin{array}{l}-0.001 \\
(0.002)\end{array}$ & $\begin{array}{c}-0.744 * * \\
(0.312)\end{array}$ \\
\hline 5.3. Basic infrastructure & $\begin{array}{l}-0.003 * * \\
(0.002)\end{array}$ & $\begin{array}{c}-0.184 * \\
(0.036)\end{array}$ & $\begin{array}{l}-0.002 \\
(0.002)\end{array}$ & $\begin{array}{c}-0.249 * \\
(0.035)\end{array}$ \\
\hline 5.4. Miscellaneous & $\begin{array}{c}-0.003 * * \\
(0.002) \\
\end{array}$ & $\begin{array}{c}-0.381 * * \\
(0.242)\end{array}$ & $\begin{array}{l}-0.002 \\
(0.002)\end{array}$ & $\begin{array}{l}-0.893 \\
(0.234)\end{array}$ \\
\hline $\begin{array}{l}\text { Productive environment } \\
\text { (all funds ERDF+CF) }\end{array}$ & $\begin{array}{l}-0.006^{*} \\
(0.002)\end{array}$ & $\begin{array}{l}-0.024 * \\
(0.004)\end{array}$ & $\begin{array}{c}-0.007 * \\
(0.002)\end{array}$ & $\begin{array}{c}-0.032 * \\
(0.004)\end{array}$ \\
\hline $\begin{array}{l}\text { Human resources } \\
\text { (all funds ERDF+CF) }\end{array}$ & $\begin{array}{c}-0.009 * \\
(0.002) \\
\end{array}$ & $\begin{array}{c}-0.227 * \\
(0.040) \\
\end{array}$ & $\begin{array}{c}-0.007 * \\
(0.002) \\
\end{array}$ & $\begin{array}{c}-0.269 * \\
(0.038) \\
\end{array}$ \\
\hline $\begin{array}{l}\text { Basic infrastructure } \\
\text { (all funds ERDF+CF) }\end{array}$ & $\begin{array}{l}-0.006^{*} \\
(0.002)\end{array}$ & $\begin{array}{l}-0.010 * \\
(0.001)\end{array}$ & $\begin{array}{c}-0.007 * \\
(0.002)\end{array}$ & $\begin{array}{c}-0.013 * \\
(0.001)\end{array}$ \\
\hline $\begin{array}{l}\text { Miscellaneous } \\
\text { (all funds ERDF+CF) }\end{array}$ & $\begin{array}{l}-0.009 * \\
(0.002)\end{array}$ & $\begin{array}{c}-0.409 * \\
(0.042)\end{array}$ & $\begin{array}{c}-0.009 * \\
(0.002)\end{array}$ & $\begin{array}{c}-0.448^{*} \\
(0.040)\end{array}$ \\
\hline
\end{tabular}

Notes: Td - estimates with treatment dummy, Tint - with treatment intensity. exp. cat. - expenditure category. Upper number is estimated parameter on $\mathrm{DiD}$, bottom reports robust standard error. $* * *, * *$ and $*$ indicate statistically significant estimated DiD at $10 \%, 5 \%$ and $1 \%$ levels, respectively. Table reports estimated parameter on DiD retrieved from estimations available upon request from the corresponding author. Estimations include full sample, but are performed over two alternative (2009-2014 and 2010-2014) post-policy periods that compared with general estimations do not cover years just before and during the crisis and starts after the year when old $(n+2)$ and new $(n+3)$ EU MS could spend the last allocation available. Encompassing longer period, i.e. including year 2015 or 2016 could at some extent cover the effects of the allocations of the next programming period (2007-2013)

Source: composed by authors. 
Table E2. Estimated DiD parameters for the sample without PIIGS and the Baltics

\begin{tabular}{|c|c|c|c|c|c|c|c|c|c|c|}
\hline \multirow{3}{*}{$\begin{array}{l}\text { Fund / expenditure } \\
\text { category }\end{array}$} & \multirow{3}{*}{ 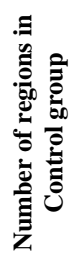 } & \multirow{3}{*}{ 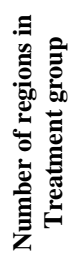 } & \multicolumn{8}{|c|}{ Estimated DiD parameters for alternative post-policy period } \\
\hline & & & \multicolumn{2}{|c|}{ 2007-2011 } & \multicolumn{2}{|c|}{ 2007-2012 } & \multicolumn{2}{|c|}{$2007-2013$} & \multicolumn{2}{|c|}{ 2007-2014 } \\
\hline & & & Td & Tint & Td & Tint & Td & Tint & Td & Tint \\
\hline All funds and all exp. cat. & 224 & 752 & $\begin{array}{l}-0.003 \\
(0.003)\end{array}$ & $\begin{array}{c}-0.005^{*} \\
(0.001)\end{array}$ & $\begin{array}{l}-0.004 \\
(0.003)\end{array}$ & $\begin{array}{c}-0.007 * \\
(0.001)\end{array}$ & $\begin{array}{l}-0.004 \\
(0.003)\end{array}$ & $\begin{array}{c}-0.007 * \\
(0.001)\end{array}$ & $\begin{array}{r}-0.004 \\
(0.003)\end{array}$ & $\begin{array}{c}-0.007 * \\
(0.001)\end{array}$ \\
\hline $\begin{array}{l}\text { 1. ERDF Obj. } 1 \\
\text { (all exp. cat.) }\end{array}$ & 731 & 245 & $\begin{array}{c}-0.009 * \\
(0.003) \\
\end{array}$ & $\begin{array}{c}-0.006^{*} \\
(0.001) \\
\end{array}$ & $\begin{array}{c}-0.011 * \\
(0.003)\end{array}$ & $\begin{array}{c}-0.009 * \\
(0.001) \\
\end{array}$ & $\begin{array}{l}-0.012 \\
(0.025) \\
\end{array}$ & $\begin{array}{c}-0.010^{*} \\
(0.001) \\
\end{array}$ & $\begin{array}{c}-0.010^{*} \\
(0.003)\end{array}$ & $\begin{array}{c}-0.009 * \\
(0.001)\end{array}$ \\
\hline $\begin{array}{l}\text { 1.1. Productive } \\
\text { environment }\end{array}$ & 732 & 244 & $\begin{array}{c}-0.009^{*} \\
(0.003)\end{array}$ & $\begin{array}{c}-0.015^{*} \\
(0.006)\end{array}$ & $\begin{array}{c}-0.011^{*} \\
(0.003)\end{array}$ & $\begin{array}{c}-0.021^{*} \\
(0.005)\end{array}$ & $\begin{array}{l}-0.012 \\
(0.003)\end{array}$ & $\begin{array}{c}-0.024 * \\
(0.006)\end{array}$ & $\begin{array}{c}-0.010^{*} \\
(0.003)\end{array}$ & $\begin{array}{c}-0.024 * \\
(0.006)\end{array}$ \\
\hline 1.2. Human resources & 854 & 122 & $\begin{array}{c}-0.013^{*} \\
(0.003)\end{array}$ & $\begin{array}{c}-0.133 * * \\
(0.056)\end{array}$ & $\begin{array}{c}-0.015^{*} \\
(0.003)\end{array}$ & $\begin{array}{c}-0.154 * \\
(0.054)\end{array}$ & $\begin{array}{c}-0.014 * \\
(0.003)\end{array}$ & $\begin{array}{c}-0.199 * \\
(0.062)\end{array}$ & $\begin{array}{c}-0.010 * \\
(0.003)\end{array}$ & $\begin{array}{c}-0.166^{*} \\
(0.054)\end{array}$ \\
\hline 1.3. Basic infrastructure & 737 & 239 & $\begin{array}{c}-0.009^{*} \\
(0.003)\end{array}$ & $\begin{array}{l}-0.009 * \\
(0.001)\end{array}$ & $\begin{array}{l}-0.011^{*} \\
(0.003)\end{array}$ & $\begin{array}{c}-0.011^{*} \\
(0.003)\end{array}$ & $\begin{array}{l}-0.013^{*} \\
(0.003)\end{array}$ & $\begin{array}{c}-0.014 * \\
(0.003)\end{array}$ & $\begin{array}{c}-0.011 * \\
(0.003)\end{array}$ & $\begin{array}{c}-0.013 * \\
(0.002)\end{array}$ \\
\hline 1.4. Miscellaneous & 767 & 209 & $\begin{array}{c}-0.010^{*} \\
(0.003)\end{array}$ & $\begin{array}{c}-0.306^{*} \\
(0.064)\end{array}$ & $\begin{array}{l}-0.012 * \\
(0.003)\end{array}$ & $\begin{array}{c}-0.380^{*} \\
(0.062)\end{array}$ & $\begin{array}{c}-0.014^{*} \\
(0.003)\end{array}$ & $\begin{array}{c}-0.431^{*} \\
(0.068)\end{array}$ & $\begin{array}{c}-0.012 * \\
(0.003)\end{array}$ & $\begin{array}{c}-0.353^{*} \\
(0.064)\end{array}$ \\
\hline $\begin{array}{l}\text { 2. ERDF Obj. } 2 \\
\text { (all exp. cat.) }\end{array}$ & 522 & 454 & $\begin{array}{c}0.004 \\
(0.003)\end{array}$ & $\begin{array}{c}0.026 \\
(0.019)\end{array}$ & $\begin{array}{l}0.006^{* * *} \\
(0.003)\end{array}$ & $\begin{array}{c}0.036 * * * \\
(0.018)\end{array}$ & $\begin{array}{c}0.006 * * * \\
(0.003)\end{array}$ & $\begin{array}{c}0.034 \\
(0.021)\end{array}$ & $\begin{array}{c}0.005 \\
(0.003)\end{array}$ & $\begin{array}{c}0.037 * * * \\
(0.019)\end{array}$ \\
\hline $\begin{array}{l}\text { 2.1. Productive } \\
\text { environment }\end{array}$ & 524 & 452 & $\begin{array}{c}0.004 \\
(0.003)\end{array}$ & $\begin{array}{c}0.048 \\
(0.027)\end{array}$ & $\begin{array}{c}0.006^{* * *} \\
(0.003)\end{array}$ & $\begin{array}{c}0.055^{* * *} \\
(0.027)\end{array}$ & $\begin{array}{c}0.006 * * \\
(0.003)\end{array}$ & $\begin{array}{c}0.060 * * \\
(0.029)\end{array}$ & $\begin{array}{c}0.005 \\
(0.003)\end{array}$ & $\begin{array}{c}0.054 * * * \\
(0.028)\end{array}$ \\
\hline 2.2. Human resources & 788 & 188 & $\begin{array}{l}-0.003 \\
(0.003) \\
\end{array}$ & $\begin{array}{l}-0.494 \\
(0.375) \\
\end{array}$ & $\begin{array}{l}-0.003 \\
(0.003) \\
\end{array}$ & $\begin{array}{l}-0.391 \\
(0.383) \\
\end{array}$ & $\begin{array}{l}-0.002 \\
(0.003) \\
\end{array}$ & $\begin{array}{l}-0.227 \\
(0.425)\end{array}$ & $\begin{array}{l}-0.001 \\
(0.003)\end{array}$ & $\begin{array}{l}-0.104 \\
(0.400)\end{array}$ \\
\hline 2.3. Basic infrastructure & 582 & 394 & $\begin{array}{c}0.003 \\
(0.003) \\
\end{array}$ & $\begin{array}{c}0.031 \\
(0.047)\end{array}$ & $\begin{array}{c}0.005 \\
(0.003)\end{array}$ & $\begin{array}{c}0.057 \\
(0.047)\end{array}$ & $\begin{array}{c}0.005 \\
(0.003)\end{array}$ & $\begin{array}{c}0.040 \\
(0.053)\end{array}$ & $\begin{array}{c}0.003 \\
(0.003)\end{array}$ & $\begin{array}{c}0.044 \\
(0.051)\end{array}$ \\
\hline 2.4. Miscellaneous & 608 & 368 & $\begin{array}{c}0.001 \\
(0.003) \\
\end{array}$ & $\begin{array}{c}0.338 \\
(0.461) \\
\end{array}$ & $\begin{array}{c}0.003 \\
(0.003) \\
\end{array}$ & $\begin{array}{c}0.629 \\
(0.465) \\
\end{array}$ & $\begin{array}{c}0.003 \\
(0.003) \\
\end{array}$ & $\begin{array}{c}0.469 \\
(0.514) \\
\end{array}$ & $\begin{array}{c}0.003 \\
(0.003) \\
\end{array}$ & $\begin{array}{c}0.541 \\
(0.491) \\
\end{array}$ \\
\hline $\begin{array}{l}\text { 3. Cohesion fund } \\
\text { (all exp. cat.) }\end{array}$ & 868 & 108 & $\begin{array}{c}-0.009 * \\
(0.003)\end{array}$ & $\begin{array}{l}-0.005 \\
(0.004)\end{array}$ & $\begin{array}{c}-0.016^{*} \\
(0.003)\end{array}$ & $\begin{array}{c}-0.011 * \\
(0.004)\end{array}$ & $\begin{array}{c}-0.016^{*} \\
(0.003)\end{array}$ & $\begin{array}{c}-0.010 * * \\
(0.005)\end{array}$ & $\begin{array}{c}-0.011^{*} \\
(0.003)\end{array}$ & $\begin{array}{l}-0.009 \\
(0.005)\end{array}$ \\
\hline 3.3. Basic infrastructure & 868 & 108 & $\begin{array}{c}-0.009^{*} \\
(0.003)\end{array}$ & $\begin{array}{l}-0.006 \\
(0.005)\end{array}$ & $\begin{array}{l}-0.016^{*} \\
(0.003)\end{array}$ & $\begin{array}{c}-0.012^{*} \\
(0.004)\end{array}$ & $\begin{array}{l}-0.016^{*} \\
(0.003)\end{array}$ & $\begin{array}{c}-0.010 * * \\
(0.005)\end{array}$ & $\begin{array}{c}-0.011^{*} \\
(0.003)\end{array}$ & $\begin{array}{l}-0.009 \\
(0.005)\end{array}$ \\
\hline 3.4. Miscellaneous & 894 & 82 & $\begin{array}{c}0.003 \\
(0.004)\end{array}$ & $\begin{array}{c}0.181 \\
(0.198)\end{array}$ & $\begin{array}{l}-0.001 \\
(0.004)\end{array}$ & $\begin{array}{c}0.090 \\
(0.203)\end{array}$ & $\begin{array}{l}-0.004 \\
(0.004)\end{array}$ & $\begin{array}{c}0.306 \\
(0.209)\end{array}$ & $\begin{array}{l}-0.004 \\
(0.005)\end{array}$ & $\begin{array}{c}0.276 \\
(0.220)\end{array}$ \\
\hline 4. Urban (all exp. cat.) & 921 & 55 & $\begin{array}{l}-0.003 \\
(0.004)\end{array}$ & $\begin{array}{l}-0.062 \\
(0.163)\end{array}$ & $\begin{array}{l}-0.004 \\
(0.004)\end{array}$ & $\begin{array}{c}-0.091 \\
(0.158)\end{array}$ & $\begin{array}{l}-0.006 \\
(0.004)\end{array}$ & $\begin{array}{l}-0.178 \\
(0.175)\end{array}$ & $\begin{array}{l}-0.005 \\
(0.004)\end{array}$ & $\begin{array}{l}-0.151 \\
(0.156)\end{array}$ \\
\hline $\begin{array}{l}\text { 4.1. Productive } \\
\text { environment }\end{array}$ & 931 & 45 & $\begin{array}{l}-0.001 \\
(0.006) \\
\end{array}$ & $\begin{array}{c}0.132 \\
(0.794) \\
\end{array}$ & $\begin{array}{l}-0.003 \\
(0.005) \\
\end{array}$ & $\begin{array}{c}0.319 \\
(0.768) \\
\end{array}$ & $\begin{array}{l}-0.005 \\
(0.006) \\
\end{array}$ & $\begin{array}{l}-0.057 \\
(0.866) \\
\end{array}$ & $\begin{array}{l}-0.005 \\
(0.004) \\
\end{array}$ & $\begin{array}{l}-0.105 \\
(0.763) \\
\end{array}$ \\
\hline 4.2. Human resources & 925 & 51 & $\begin{array}{l}-0.003 \\
(0.004) \\
\end{array}$ & $\begin{array}{l}-0.406 \\
(1.233) \\
\end{array}$ & $\begin{array}{l}-0.005 \\
(0.005) \\
\end{array}$ & $\begin{array}{l}-0.314 \\
(1.177) \\
\end{array}$ & $\begin{array}{l}-0.006 \\
(0.005) \\
\end{array}$ & $\begin{array}{l}-0.644 \\
(1.325) \\
\end{array}$ & $\begin{array}{l}-0.006 \\
(0.004)\end{array}$ & $\begin{array}{l}-0.730 \\
(1.176) \\
\end{array}$ \\
\hline 4.3. Basic infrastructure & 925 & 51 & $\begin{array}{l}-0.003 \\
(0.004)\end{array}$ & $\begin{array}{l}-0.108 \\
(0.229)\end{array}$ & $\begin{array}{l}-0.004 \\
(0.005)\end{array}$ & $\begin{array}{l}-0.174 \\
(0.217)\end{array}$ & $\begin{array}{l}-0.006 \\
(0.005)\end{array}$ & $\begin{array}{l}-0.300 \\
(0.247)\end{array}$ & $\begin{array}{l}-0.006 \\
(0.004)\end{array}$ & $\begin{array}{l}-0.249 \\
(0.217)\end{array}$ \\
\hline 4.4. Miscellaneous & 928 & 48 & $\begin{array}{l}-0.003 \\
(0.004) \\
\end{array}$ & $\begin{array}{l}-1.414 \\
(2.769) \\
\end{array}$ & $\begin{array}{l}-0.004 \\
(0.004) \\
\end{array}$ & $\begin{array}{l}-1.640 \\
(2.656) \\
\end{array}$ & $\begin{array}{l}-0.006 \\
(0.005) \\
\end{array}$ & $\begin{array}{l}-3.080 \\
(2.994) \\
\end{array}$ & $\begin{array}{l}-0.006 \\
(0.005) \\
\end{array}$ & $\begin{array}{l}-2.804 \\
(2.713) \\
\end{array}$ \\
\hline $\begin{array}{l}\text { 5. ERDF INTERREG } \\
\text { IIIA (all exp. cat.) }\end{array}$ & 672 & 304 & $\begin{array}{l}-0.001 \\
(0.003)\end{array}$ & $\begin{array}{l}-0.027 \\
(0.029)\end{array}$ & $\begin{array}{l}-0.003 \\
(0.003)\end{array}$ & $\begin{array}{c}-0.053 * * * \\
(0.028)\end{array}$ & $\begin{array}{l}-0.001 \\
(0.003)\end{array}$ & $\begin{array}{c}-0.074 * * \\
(0.030)\end{array}$ & $\begin{array}{l}-0.001 \\
(0.003)\end{array}$ & $\begin{array}{c}-0.059 * * \\
(0.028)\end{array}$ \\
\hline $\begin{array}{l}\text { 5.1. Productive } \\
\text { environment }\end{array}$ & 672 & 304 & $\begin{array}{c}-0.001 \\
(0.003)\end{array}$ & $\begin{array}{c}0.016 \\
(0.063) \\
\end{array}$ & $\begin{array}{l}-0.003 \\
(0.003)\end{array}$ & $\begin{array}{l}-0.015 \\
(0.062)\end{array}$ & $\begin{array}{c}-0.001 \\
(0.003)\end{array}$ & $\begin{array}{l}-0.040 \\
(0.069)\end{array}$ & $\begin{array}{c}-0.001 \\
(0.003)\end{array}$ & $\begin{array}{c}-0.037 \\
(0.065)\end{array}$ \\
\hline 5.2. Human resources & 676 & 300 & $\begin{array}{c}-0.001 \\
(0.003) \\
\end{array}$ & $\begin{array}{l}-0.222 \\
(0.462) \\
\end{array}$ & $\begin{array}{l}-0.003 \\
(0.003) \\
\end{array}$ & $\begin{array}{l}-0.431 \\
(0.458) \\
\end{array}$ & $\begin{array}{l}-0.001 \\
(0.003) \\
\end{array}$ & $\begin{array}{l}-0.607 \\
(0.503) \\
\end{array}$ & $\begin{array}{l}-0.001 \\
(0.003) \\
\end{array}$ & $\begin{array}{l}-0.415 \\
(0.470) \\
\end{array}$ \\
\hline 5.3. Basic infrastructure & 672 & 304 & $\begin{array}{l}-0.001 \\
(0.003) \\
\end{array}$ & $\begin{array}{c}-0.099 * * * \\
(0.050) \\
\end{array}$ & $\begin{array}{l}-0.003 \\
(0.003) \\
\end{array}$ & $\begin{array}{c}-0.157 * \\
(0.051)\end{array}$ & $\begin{array}{l}-0.001 \\
(0.003) \\
\end{array}$ & $\begin{array}{c}-0.192 * \\
(0.057)\end{array}$ & $\begin{array}{l}-0.001 \\
(0.003)\end{array}$ & $\begin{array}{c}-0.143^{*} \\
(0.053) \\
\end{array}$ \\
\hline 5.4. Miscellaneous & 928 & 48 & $\begin{array}{c}-0.001 \\
(0.003)\end{array}$ & $\begin{array}{l}-0.112 \\
(0.344)\end{array}$ & $\begin{array}{l}-0.003 \\
(0.003)\end{array}$ & $\begin{array}{l}-0.417 \\
(0.346)\end{array}$ & $\begin{array}{c}-0.001 \\
(0.003)\end{array}$ & $\begin{array}{l}-0.650 \\
(0.380)\end{array}$ & $\begin{array}{l}-0.001 \\
(0.003)\end{array}$ & $\begin{array}{c}-0.568 \\
(0.365)\end{array}$ \\
\hline $\begin{array}{l}\text { Productive environment } \\
\text { (all funds ERDF+CF) }\end{array}$ & 226 & 750 & $\begin{array}{l}-0.003 \\
(0.003) \\
\end{array}$ & $\begin{array}{c}-0.013^{* *} * \\
(0.006)\end{array}$ & $\begin{array}{l}-0.004 \\
(0.003) \\
\end{array}$ & $\begin{array}{c}-0.020^{*} \\
(0.006)\end{array}$ & $\begin{array}{l}-0.005 \\
(0.003) \\
\end{array}$ & $\begin{array}{c}-0.023 * \\
(0.006) \\
\end{array}$ & $\begin{array}{l}-0.004 \\
(0.003) \\
\end{array}$ & $\begin{array}{c}-0.021 * \\
(0.007)\end{array}$ \\
\hline $\begin{array}{l}\text { Human resources } \\
\text { (all funds ERDF+CF) }\end{array}$ & 448 & 528 & $\begin{array}{c}-0.005 * * * \\
(0.003)\end{array}$ & $\begin{array}{c}-0.140 * \\
(0.055)\end{array}$ & $\begin{array}{c}-0.006^{* *} \\
(0.003)\end{array}$ & $\begin{array}{c}-0.172 * \\
(0.057)\end{array}$ & $\begin{array}{l}-0.006 \\
(0.003) \\
\end{array}$ & $\begin{array}{c}-0.207 * \\
(0.062) \\
\end{array}$ & $\begin{array}{l}-0.004 \\
(0.003) \\
\end{array}$ & $\begin{array}{c}-0.172^{*} \\
(0.060)\end{array}$ \\
\hline $\begin{array}{l}\text { Basic infrastructure } \\
\text { (all funds ERDF+CF) }\end{array}$ & 265 & 711 & $\begin{array}{l}-0.004 \\
(0.003)\end{array}$ & $\begin{array}{c}-0.006^{*} \\
(0.002)\end{array}$ & $\begin{array}{l}-0.004 \\
(0.003)\end{array}$ & $\begin{array}{c}-0.009^{*} \\
(0.001)\end{array}$ & $\begin{array}{l}-0.005 \\
(0.003)\end{array}$ & $\begin{array}{c}-0.009 * \\
(0.002)\end{array}$ & $\begin{array}{l}-0.005 \\
(0.003)\end{array}$ & $\begin{array}{c}-0.008 * \\
(0.002)\end{array}$ \\
\hline $\begin{array}{l}\text { Miscellaneous } \\
\text { (all funds ERDF+CF) }\end{array}$ & 301 & 675 & $\begin{array}{l}-0.005 * * * \\
(0.003)\end{array}$ & $\begin{array}{c}-0.235^{*} \\
(0.060)\end{array}$ & $\begin{array}{c}-0.006^{* *} \\
(0.003)\end{array}$ & $\begin{array}{c}-0.333^{*} \\
(0.059)\end{array}$ & $\begin{array}{c}-0.007 * * \\
(0.003)\end{array}$ & $\begin{array}{c}-0.357 * \\
(0.062)\end{array}$ & $\begin{array}{l}-0.006 \\
(0.003)\end{array}$ & $\begin{array}{c}-0.282^{*} \\
(0.065)\end{array}$ \\
\hline
\end{tabular}

Notes: Td - estimates with treatment dummy, Tint - with treatment intensity. exp. cat. - expenditure category. Upper number is estimated parameter on DiD, bottom reports robust standard error. $* * *, * *$ and $*$ indicate statistically significant estimated DiD at $10 \%, 5 \%$ and $1 \%$ levels, respectively. Table reports estimated parameter on DiD retrieved from estimations available upon request from the corresponding author. Estimations are performed on reduced sample ( 976 regions) over four general post-policy periods. Sample does not cover regions of Portugal, Italy, Ireland, Greece, Spain, Lithuania, Latvia and Estonia that were considered as affected by Great Financial Crysis the most. 
Table E3. Estimated DiD parameters for the sample without least and most intensively funded regions

\begin{tabular}{|c|c|c|c|c|c|c|c|c|c|c|}
\hline \multirow{3}{*}{$\begin{array}{l}\text { Fund / expenditure } \\
\text { category }\end{array}$} & \multirow{3}{*}{ 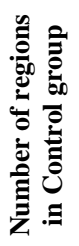 } & \multirow{3}{*}{ 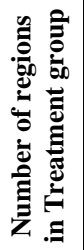 } & \multicolumn{8}{|c|}{ Estimated DiD parameters for alternative post-policy period } \\
\hline & & & \multicolumn{2}{|c|}{ 2007-2011 } & \multicolumn{2}{|c|}{ 2007-2012 } & \multicolumn{2}{|c|}{$2007-2013$} & \multicolumn{2}{|c|}{ 2007-2014 } \\
\hline & & & Td & Tint & Td & Tint & Td & Tint & Td & Tint \\
\hline $\begin{array}{l}\text { All funds and } \\
\text { all exp. cat. }\end{array}$ & 244 & 908 & $\begin{array}{l}-0.004 \\
(0.002)\end{array}$ & $\begin{array}{l}-0.006^{*} \\
(0.001) \\
\end{array}$ & $\begin{array}{c}-0.005 * * \\
(0.002) \\
\end{array}$ & $\begin{array}{c}-0.008 * \\
(0.001)\end{array}$ & $\begin{array}{c}-0.005 * * \\
(0.002) \\
\end{array}$ & $\begin{array}{c}-0.009 * \\
(0.001) \\
\end{array}$ & $\begin{array}{c}-0.005 * * \\
(0.003) \\
\end{array}$ & $\begin{array}{c}-0.008 * \\
(0.001) \\
\end{array}$ \\
\hline $\begin{array}{l}\text { 1. ERDF Obj. } 1 \\
\text { (all exp. cat.) }\end{array}$ & 789 & 363 & $\begin{array}{c}-0.011 * \\
(0.002) \\
\end{array}$ & $\begin{array}{c}-0.007 * \\
(0.001) \\
\end{array}$ & $\begin{array}{c}-0.014 * \\
(0.002) \\
\end{array}$ & $\begin{array}{c}-0.011^{*} \\
(0.001) \\
\end{array}$ & $\begin{array}{l}-0.015 \\
(0.021) \\
\end{array}$ & $\begin{array}{c}-0.012 * \\
(0.001) \\
\end{array}$ & $\begin{array}{c}-0.013 * \\
(0.002) \\
\end{array}$ & $\begin{array}{c}-0.011 * \\
(0.001) \\
\end{array}$ \\
\hline 1.1. Productive environment & 790 & 362 & $\begin{array}{l}-0.011 * \\
(0.002)\end{array}$ & $\begin{array}{l}-0.018 * \\
(0.005)\end{array}$ & $\begin{array}{l}-0.014 * \\
(0.002)\end{array}$ & $\begin{array}{c}-0.026^{*} \\
(0.004)\end{array}$ & $\begin{array}{l}-0.015 \\
(0.002)\end{array}$ & $\begin{array}{l}-0.030 * \\
(0.005)\end{array}$ & $\begin{array}{c}-0.013^{*} \\
(0.002)\end{array}$ & $\begin{array}{c}-0.029 * \\
(0.005)\end{array}$ \\
\hline 1.2. Human resources & 959 & 193 & $\begin{array}{l}-0.016^{*} \\
(0.002)\end{array}$ & $\begin{array}{l}-0.166^{*} \\
(0.047)\end{array}$ & $\begin{array}{c}-0.018 * \\
(0.002)\end{array}$ & $\begin{array}{c}-0.192^{*} \\
(0.045)\end{array}$ & $\begin{array}{c}-0.018 * \\
(0.003)\end{array}$ & $\begin{array}{c}-0.249 * \\
(0.051)\end{array}$ & $\begin{array}{c}-0.012 * \\
(0.002)\end{array}$ & $\begin{array}{c}-0.208 * \\
(0.045)\end{array}$ \\
\hline 1.3. Basic infrastructure & 794 & 358 & $\begin{array}{l}-0.011 * \\
(0.002)\end{array}$ & $\begin{array}{c}-0.011 * \\
(0.001)\end{array}$ & $\begin{array}{c}-0.014 * \\
(0.002)\end{array}$ & $\begin{array}{c}-0.014^{*} \\
(0.002)\end{array}$ & $\begin{array}{c}-0.016^{*} \\
(0.003)\end{array}$ & $\begin{array}{c}-0.018 * \\
(0.003)\end{array}$ & $\begin{array}{c}-0.013^{*} \\
(0.003)\end{array}$ & $\begin{array}{c}-0.016^{*} \\
(0.001)\end{array}$ \\
\hline 1.4. Miscellaneous & 830 & 322 & $\begin{array}{l}-0.012 * \\
(0.002)\end{array}$ & $\begin{array}{c}-0.382 * \\
(0.054)\end{array}$ & $\begin{array}{c}-0.015^{*} \\
(0.002)\end{array}$ & $\begin{array}{c}-0.475^{*} \\
(0.052)\end{array}$ & $\begin{array}{c}-0.018 * \\
(0.003)\end{array}$ & $\begin{array}{c}-0.539 * \\
(0.057)\end{array}$ & $\begin{array}{c}-0.015^{*} \\
(0.003)\end{array}$ & $\begin{array}{c}-0.441^{*} \\
(0.054)\end{array}$ \\
\hline $\begin{array}{l}\text { 2. ERDF Obj. } 2 \\
\text { (all exp. cat.) }\end{array}$ & 635 & 517 & $\begin{array}{l}0.005 * * \\
(0.002)\end{array}$ & $\begin{array}{l}0.033 * * \\
(0.016)\end{array}$ & $\begin{array}{l}0.008^{*} \\
(0.002)\end{array}$ & $\begin{array}{l}0.045^{*} \\
(0.015)\end{array}$ & $\begin{array}{l}0.007 * \\
(0.003)\end{array}$ & $\begin{array}{c}0.042 * * \\
(0.018)\end{array}$ & $\begin{array}{l}0.006 * * \\
(0.003)\end{array}$ & $\begin{array}{l}0.046 * \\
(0.016)\end{array}$ \\
\hline 2.1. Productive environment & 635 & 517 & $\begin{array}{c}0.005^{* *} * \\
(0.002)\end{array}$ & $\begin{array}{l}0.059 * \\
(0.023)\end{array}$ & $\begin{array}{l}0.008^{*} \\
(0.002)\end{array}$ & $\begin{array}{l}0.069 * \\
(0.023)\end{array}$ & $\begin{array}{l}0.007 * \\
(0.003)\end{array}$ & $\begin{array}{l}0.075^{*} \\
(0.024)\end{array}$ & $\begin{array}{l}0.006 * * \\
(0.003)\end{array}$ & $\begin{array}{l}0.067^{*} \\
(0.024)\end{array}$ \\
\hline 2.2. Human resources & 955 & 197 & $\begin{array}{c}-0.004 * * * \\
(0.002)\end{array}$ & $\begin{array}{c}-0.617 * * * \\
(0.312) \\
\end{array}$ & $\begin{array}{l}-0.003 \\
(0.002)\end{array}$ & $\begin{array}{l}-0.489 \\
(0.319)\end{array}$ & $\begin{array}{l}-0.003 \\
(0.003)\end{array}$ & $\begin{array}{l}-0.284 \\
(0.354)\end{array}$ & $\begin{array}{l}-0.002 \\
(0.003)\end{array}$ & $\begin{array}{l}-0.130 \\
(0.333)\end{array}$ \\
\hline 2.3. Basic infrastructure & 686 & 466 & $\begin{array}{c}0.004 * * * \\
(0.002) \\
\end{array}$ & $\begin{array}{c}0.038 \\
(0.039) \\
\end{array}$ & $\begin{array}{l}0.006^{*} \\
(0.002) \\
\end{array}$ & $\begin{array}{c}0.071 * * * \\
(0.039) \\
\end{array}$ & $\begin{array}{c}0.006 * * \\
(0.003) \\
\end{array}$ & $\begin{array}{c}0.050 \\
(0.044) \\
\end{array}$ & $\begin{array}{c}0.004 \\
(0.003) \\
\end{array}$ & $\begin{array}{c}0.055 \\
(0.042) \\
\end{array}$ \\
\hline 2.4. Miscellaneous & 716 & 436 & $\begin{array}{c}0.002 \\
(0.002) \\
\end{array}$ & $\begin{array}{c}0.423 \\
(0.384) \\
\end{array}$ & $\begin{array}{c}0.004 * * * \\
(0.002) \\
\end{array}$ & $\begin{array}{c}0.787 * * \\
(0.387) \\
\end{array}$ & $\begin{array}{c}0.004 \\
(0.003) \\
\end{array}$ & $\begin{array}{c}0.586 \\
(0.429) \\
\end{array}$ & $\begin{array}{c}0.003 \\
(0.003) \\
\end{array}$ & $\begin{array}{c}0.676 \\
(0.409) \\
\end{array}$ \\
\hline $\begin{array}{l}\text { 3. Cohesion fund } \\
\text { (all exp. cat.) }\end{array}$ & 950 & 202 & $\begin{array}{c}-0.011^{*} \\
(0.003)\end{array}$ & $\begin{array}{c}-0.007 * * * \\
(0.004)\end{array}$ & $\begin{array}{c}-0.019 * \\
(0.002)\end{array}$ & $\begin{array}{c}-0.014^{*} \\
(0.004)\end{array}$ & $\begin{array}{c}-0.020^{*} \\
(0.003)\end{array}$ & $\begin{array}{c}-0.012 * \\
(0.004)\end{array}$ & $\begin{array}{l}-0.015^{*} \\
(0.003)\end{array}$ & $\begin{array}{c}-0.011^{*} \\
(0.004)\end{array}$ \\
\hline 3.3. Basic infrastructure & 950 & 202 & $\begin{array}{c}-0.011^{*} \\
(0.003)\end{array}$ & $\begin{array}{c}-0.007 * * * \\
(0.004)\end{array}$ & $\begin{array}{l}-0.019 * \\
(0.002)\end{array}$ & $\begin{array}{c}-0.015^{*} \\
(0.004)\end{array}$ & $\begin{array}{c}-0.020^{*} \\
(0.003) \\
\end{array}$ & $\begin{array}{c}-0.013 * \\
(0.004)\end{array}$ & $\begin{array}{c}-0.015^{*} \\
(0.003)\end{array}$ & $\begin{array}{c}-0.011^{*} \\
(0.004)\end{array}$ \\
\hline 3.4. Miscellaneous & 1053 & 99 & $\begin{array}{c}0.003 \\
(0.004)\end{array}$ & $\begin{array}{c}0.227 \\
(0.165)\end{array}$ & $\begin{array}{l}-0.002 \\
(0.004)\end{array}$ & $\begin{array}{c}0.113 \\
(0.169)\end{array}$ & $\begin{array}{l}-0.005 \\
(0.004)\end{array}$ & $\begin{array}{c}0.382 * * \\
(0.175)\end{array}$ & $\begin{array}{l}-0.004 \\
(0.004)\end{array}$ & $\begin{array}{c}0.345 * * * \\
(0.183)\end{array}$ \\
\hline $\begin{array}{l}\text { 4. Urban } \\
\text { (all exp. cat.) }\end{array}$ & 1084 & 68 & $\begin{array}{l}-0.003 \\
(0.003) \\
\end{array}$ & $\begin{array}{l}-0.078 \\
(0.136) \\
\end{array}$ & $\begin{array}{l}-0.005 \\
(0.003)\end{array}$ & $\begin{array}{l}-0.113 \\
(0.131) \\
\end{array}$ & $\begin{array}{c}-0.007 * * \\
(0.004)\end{array}$ & $\begin{array}{l}-0.222 \\
(0.145)\end{array}$ & $\begin{array}{c}-0.007 * * * \\
(0.004)\end{array}$ & $\begin{array}{l}-0.188 \\
(0.130) \\
\end{array}$ \\
\hline 4.1. Productive environment & 1095 & 57 & $\begin{array}{l}-0.002 \\
(0.005) \\
\end{array}$ & $\begin{array}{c}0.165 \\
(0.661) \\
\end{array}$ & $\begin{array}{l}-0.003 \\
(0.004)\end{array}$ & $\begin{array}{c}0.398 \\
(0.640) \\
\end{array}$ & $\begin{array}{l}-0.007 \\
(0.005) \\
\end{array}$ & $\begin{array}{l}-0.071 \\
(0.722)\end{array}$ & $\begin{array}{c}-0.007 * * * \\
(0.004)\end{array}$ & $\begin{array}{l}-0.131 \\
(0.636) \\
\end{array}$ \\
\hline 4.2. Human resources & 1093 & 59 & $\begin{array}{l}-0.004 \\
(0.004) \\
\end{array}$ & $\begin{array}{l}-0.508 \\
(1.028) \\
\end{array}$ & $\begin{array}{l}-0.006 \\
(0.004) \\
\end{array}$ & $\begin{array}{l}-0.392 \\
(0.981) \\
\end{array}$ & $\begin{array}{l}-0.007 \\
(0.005) \\
\end{array}$ & $\begin{array}{l}-0.805 \\
(1.104) \\
\end{array}$ & $\begin{array}{c}-0.008 * * \\
(0.004) \\
\end{array}$ & $\begin{array}{l}-0.913 \\
(0.980) \\
\end{array}$ \\
\hline 4.3. Basic infrastructure & 1085 & 67 & $\begin{array}{l}-0.003 \\
(0.004)\end{array}$ & $\begin{array}{l}-0.135 \\
(0.190)\end{array}$ & $\begin{array}{l}-0.005 \\
(0.003)\end{array}$ & $\begin{array}{l}-0.217 \\
(0.181)\end{array}$ & $\begin{array}{c}-0.008 * * \\
(0.004)\end{array}$ & $\begin{array}{c}-0.375 * * * \\
(0.206)\end{array}$ & $\begin{array}{c}-0.007 * * * \\
(0.004)\end{array}$ & $\begin{array}{l}-0.311 \\
(0.181)\end{array}$ \\
\hline 4.4. Miscellaneous & 1085 & 67 & $\begin{array}{l}-0.003 \\
(0.004)\end{array}$ & $\begin{array}{l}-1.767 \\
(2.308) \\
\end{array}$ & $\begin{array}{l}-0.005 \\
(0.003)\end{array}$ & $\begin{array}{l}-2.050 \\
(2.213) \\
\end{array}$ & $\begin{array}{c}-0.008^{* *} * \\
(0.004)\end{array}$ & $\begin{array}{l}-3.850 \\
(2.495)\end{array}$ & $\begin{array}{c}-0.007 * * * \\
(0.004)\end{array}$ & $\begin{array}{l}-3.505 \\
(2.261) \\
\end{array}$ \\
\hline $\begin{array}{l}\text { 5. ERDF INTERREG IIIA } \\
\text { (all exp. cat.) }\end{array}$ & 788 & 364 & $\begin{array}{l}-0.001 \\
(0.002)\end{array}$ & $\begin{array}{l}-0.034 \\
(0.024)\end{array}$ & $\begin{array}{l}-0.003 \\
(0.002)\end{array}$ & $\begin{array}{c}-0.066^{*} \\
(0.023)\end{array}$ & $\begin{array}{l}-0.002 \\
(0.003)\end{array}$ & $\begin{array}{c}-0.092 * \\
(0.025)\end{array}$ & $\begin{array}{l}-0.002 \\
(0.003)\end{array}$ & $\begin{array}{c}-0.073^{*} \\
(0.024)\end{array}$ \\
\hline 5.1. Productive environment & 788 & 364 & $\begin{array}{l}-0.001 \\
(0.002)\end{array}$ & $\begin{array}{c}0.020 \\
(0.053)\end{array}$ & $\begin{array}{l}-0.003 \\
(0.002)\end{array}$ & $\begin{array}{l}-0.019 \\
(0.052)\end{array}$ & $\begin{array}{l}-0.002 \\
(0.003)\end{array}$ & $\begin{array}{l}-0.050 \\
(0.058)\end{array}$ & $\begin{array}{l}-0.002 \\
(0.003)\end{array}$ & $\begin{array}{l}-0.046 \\
(0.054)\end{array}$ \\
\hline 5.2. Human resources & 798 & 354 & $\begin{array}{l}-0.001 \\
(0.002)\end{array}$ & $\begin{array}{l}-0.277 \\
(0.385)\end{array}$ & $\begin{array}{l}-0.003 \\
(0.002)\end{array}$ & $\begin{array}{l}-0.538 \\
(0.382)\end{array}$ & $\begin{array}{l}-0.001 \\
(0.003)\end{array}$ & $\begin{array}{c}-0.759 * * * \\
(0.419)\end{array}$ & $\begin{array}{l}-0.001 \\
(0.003)\end{array}$ & $\begin{array}{l}-0.518 \\
(0.392)\end{array}$ \\
\hline 5.3. Basic infrastructure & 788 & 364 & $\begin{array}{l}-0.001 \\
(0.002) \\
\end{array}$ & $\begin{array}{c}-0.124 * \\
(0.042) \\
\end{array}$ & $\begin{array}{l}-0.003 \\
(0.002) \\
\end{array}$ & $\begin{array}{c}-0.196 * \\
(0.043) \\
\end{array}$ & $\begin{array}{l}-0.002 \\
(0.003) \\
\end{array}$ & $\begin{array}{c}-0.240 * \\
(0.048) \\
\end{array}$ & $\begin{array}{l}-0.002 \\
(0.003) \\
\end{array}$ & $\begin{array}{c}-0.178 * \\
(0.044) \\
\end{array}$ \\
\hline 5.4. Miscellaneous & 789 & 363 & $\begin{array}{l}-0.001 \\
(0.002)\end{array}$ & $\begin{array}{l}-0.141 \\
(0.287)\end{array}$ & $\begin{array}{l}-0.003 \\
(0.002) \\
\end{array}$ & $\begin{array}{c}-0.522 * * * \\
(0.288) \\
\end{array}$ & $\begin{array}{l}-0.002 \\
(0.003) \\
\end{array}$ & $\begin{array}{c}-0.813^{*} \\
(0.316) \\
\end{array}$ & $\begin{array}{l}-0.002 \\
(0.003) \\
\end{array}$ & $\begin{array}{c}-0.710 * * \\
(0.304)\end{array}$ \\
\hline $\begin{array}{l}\text { Productive envi-ronment } \\
\text { (all funds ERDF+CF) }\end{array}$ & 244 & 908 & $\begin{array}{l}-0.004 \\
(0.002)\end{array}$ & $\begin{array}{l}-0.017 * \\
(0.005)\end{array}$ & $\begin{array}{c}-0.005 * * \\
(0.002)\end{array}$ & $\begin{array}{l}-0.024 \\
(0.005)\end{array}$ & $\begin{array}{c}-0.005^{* *} * \\
(0.002)\end{array}$ & $\begin{array}{c}-0.029 * \\
(0.005)\end{array}$ & $\begin{array}{c}-0.005 * * \\
(0.003) \\
\end{array}$ & $\begin{array}{c}-0.026^{*} \\
(0.005)\end{array}$ \\
\hline $\begin{array}{l}\text { Human resources } \\
\text { (all funds ERDF+CF) }\end{array}$ & 519 & 633 & $\begin{array}{c}-0.007 * \\
(0.002)\end{array}$ & $\begin{array}{c}-0.175^{*} \\
(0.046)\end{array}$ & $\begin{array}{l}-0.008 \\
(0.002)\end{array}$ & $\begin{array}{l}-0.215 \\
(0.048)\end{array}$ & $\begin{array}{l}-0.007 \\
(0.003)\end{array}$ & $\begin{array}{l}-0.259 * \\
(0.052)\end{array}$ & $\begin{array}{c}-0.005 * * * \\
(0.003)\end{array}$ & $\begin{array}{c}-0.214^{*} \\
(0.050) \\
\end{array}$ \\
\hline $\begin{array}{l}\text { Basic infrastructure } \\
\text { (all funds ERDF+CF) }\end{array}$ & 177 & 875 & $\begin{array}{l}-0.004 \\
(0.003)\end{array}$ & $\begin{array}{l}-0.007 * \\
(0.001)\end{array}$ & $\begin{array}{c}-0.005 * * \\
(0.002) \\
\end{array}$ & $\begin{array}{l}-0.011 \\
(0.001)\end{array}$ & $\begin{array}{c}-0.006^{* *} * \\
(0.003)\end{array}$ & $\begin{array}{c}-0.012 * \\
(0.001) \\
\end{array}$ & $\begin{array}{c}-0.006 * * \\
(0.003) \\
\end{array}$ & $\begin{array}{c}-0.010^{*} \\
(0.001) \\
\end{array}$ \\
\hline $\begin{array}{l}\text { Miscellaneous (all funds } \\
\text { ERDF+CF) }\end{array}$ & 312 & 840 & $\begin{array}{c}-0.007 * \\
(0.002)\end{array}$ & $\begin{array}{c}-0.294 * \\
(0.050)\end{array}$ & $\begin{array}{l}-0.008 \\
(0.002)\end{array}$ & $\begin{array}{l}-0.416 \\
(0.050)\end{array}$ & $\begin{array}{l}-0.009 \\
(0.002)\end{array}$ & $\begin{array}{c}-0.446^{*} \\
(0.052)\end{array}$ & $\begin{array}{c}-0.007 * * \\
(0.003)\end{array}$ & $\begin{array}{c}-0.352 * \\
(0.054)\end{array}$ \\
\hline
\end{tabular}

Notes: Td - estimates with treatment dummy, Tint - with treatment intensity. exp. cat. - expenditure category. Upper number is estimated parameter on DiD, bottom reports robust standard error. ***, ** and * indicate statistically significant estimated DiD at 10\%, 5\% and $1 \%$ levels, respectively. Table reports estimated parameter on DiD retrieved from estimations available upon request from the corresponding author. Estimations are performed on reduced sample (1152 regions) over four general post-policy periods. Samples does not cover regions with support intensity bellow bottom $5^{\text {th }}$ and above top $95^{\text {th }}$ percentile, i.e. below $0.005 \%$ and above $2.11 \%$ treatment intensity.

Source: composed by authors. 